Portland State University

PDXScholar

\title{
Serfs, Excluded or Governed by The State? Serfdom in Russia, an Historiographical Analysis
}

Jason Ferguson

Portland State University

Follow this and additional works at: https://pdxscholar.library.pdx.edu/open_access_etds

Part of the European History Commons

Let us know how access to this document benefits you.

Recommended Citation

Ferguson, Jason, "Serfs, Excluded or Governed by The State? Serfdom in Russia, an Historiographical Analysis" (2021). Dissertations and Theses. Paper 5803.

https://doi.org/10.15760/etd.7674

This Thesis is brought to you for free and open access. It has been accepted for inclusion in Dissertations and Theses by an authorized administrator of PDXScholar. Please contact us if we can make this document more accessible: pdxscholar@pdx.edu. 
Serfs, Excluded or Governed by The State?

Serfdom in Russia, an Historiographical Analysis

by

Jason Ferguson

A thesis submitted in partial fulfillment of the requirements for the degree of

\author{
Master of Arts \\ in \\ World History
}
Thesis Committee:
Chia Yin Hsu
Brian Turner
James Grehan
Joseph Bohling

Portland State University

2021 


\begin{abstract}
Serfdom in Russia has often been viewed in Anglo-U.S. historiography as an exceptional institution in that it emerged in the early-modern age, after serfdom in Western Europe had ended, and that it persisted for well over two centuries, spanning the Muscovite and the Imperial eras. Many historians have thus compared serfdom in Russia unfavorably to labor systems that developed in Western European nations at that time, considered to be "modern" and "free," in contrast to the "unfree" labor obtained through Russian serfdom. This thesis presents the scholars who take this view, and refers to them as "Consensus Historians," as their works are seminal and their influence is even now far-reaching. In addition to depicting Russian serfdom as a type of "unfree" labor similar to slavery, Consensus Historians maintain that the persistence of serfdom in Russia was interconnected with the "backwardness" of Russian society. The view of the Consensus Historians, who were generally active in the 1960s-1970s, has been challenged by more recent scholars, whom this chapter calls "Revisionist Historians." Using archival material not available to the Consensus Historians, as they belonged to the Anglo-U.S. side of the Cold War divide, the "Revisionists" question many of the assumptions underlying the argument of the Consensus authors, as well as their depiction of serfdom. Examining court cases, records of landed estates where enserfed peasants lived and worked, and other archival documents, the Revisionist authors argue that serfdom was in practice an institution that changed over the years, varied vastly depending on location and time, and was far less monolithic and inflexible than has been depicted by previous historians. The first two chapters deal with the claims of these two groups of authors. The third chapter
\end{abstract}


explores contemporary works that give voice to the experiences of the enserfed peasants, including several serf memoirs. This chapter gives the reader an opportunity to square the life experiences portrayed by the memoirs with the claims from the Consensus and Revisionist authors. Finally, the fourth chapter will take a step back from the Russian Empire and look at labor systems elsewhere in the long nineteenth-century world, a time of expanding world markets and sharply growing labor needs. This chapter compares and contrasts to the Russian case a variety of "free" and "un-free" labor systems that took hold around the world in this time, and aims to determine whether serfdom in Russia was uniquely or exceptionally "unfree" in an era when a wide range of coercive labor practices existed, supported by powerful Western countries and affecting millions and generations of laborers. 


\section{Table of Contents}

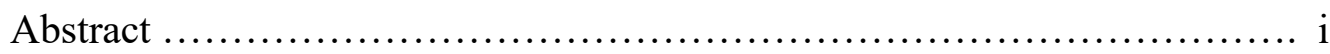

Table of Contents ................................................... iii

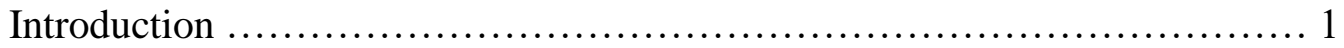

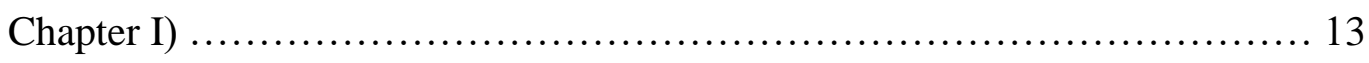

The Consensus Historians

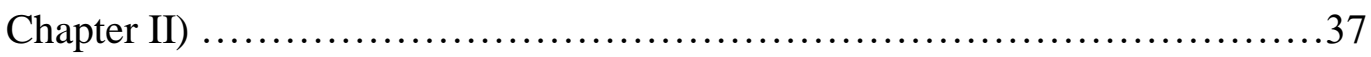

The Revisionist Historians

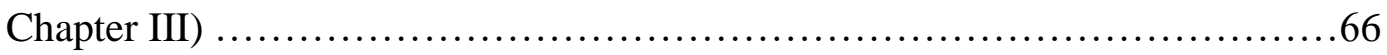

Serf Memoirs and Other Writings

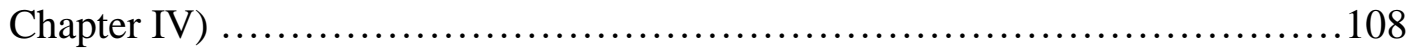

Labor Extraction in the Global Context

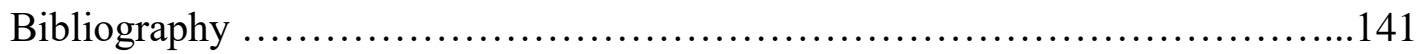




\section{INTRODUCTION}

Serfdom emerged in Muscovite Russia around the sixteenth century. It was entrenched by Muscovite legal code in the seventeenth century, extended to new territories by the young Russian Empire in the early eighteenth century, and continued to exist for another century and a half before it was finally abolished by Tsar Alexander II in 1861. The permanent codification of serfdom is considered by many historians to be marked by the 1649 Law Code, which prohibited the movement of serfs from the estates of their landowners. Serfdom in Russia lasted 212 years, from the end of the Muscovite period to the modern era. Because of the lateness of this timeframe, as serfdom in the larger European context is often viewed as a medieval institution, serfdom in Russia is also referred to as the "second serfdom." For many historians, comparing Russian historical development to that of Western Europe, Russia's "second serfdom" was an anomaly, and the reason for the empire's backwardness relative to other parts of Europe.

This thesis project is a historiographical analysis that examines how historians have interpreted the serfdom in the Russian Empire, as well as the significance of their interpretations. In the thesis, I will refer to the historians who have shaped the study of Russian serfdom, and who have contributed to the still predominant interpretation of the subject as "Consensus" historians. Their understanding of serfdom in Russia has recently been challenged by historians whom I will call "Revisionist." This project will first survey the understanding of serfdom in Russia presented by Consensus historians who tend to look to Western Europe as the model of social and economic progress and often equate serfdom with slavery. This will be Chapter I. 
Chapter II will examine the work of the Revisionist scholars, who suggest a different approach to interpreting serfdom in Russia. The Revisionist scholars raise questions about the equivalence of serfdom and slavery, and diverge from the Consensus interpretation that serfdom constituted a central mark of Russian economic backwardness in comparison to Western Europe. The Revisionists also challenge the Consensus views of the Russian state's agency in maintaining the institution of serfdom.

In Chapter III I will assess the cogency of these two differing schools of interpretation in relation to the experience of the serfs themselves, as told in contemporary accounts. Using primary sources such as serf memoirs, this chapter will highlight the strength and weaknesses of these two groups of divergent interpretations. Chapter IV will assess how these conclusions drawn from the Russian case presented in the previous chapter might assist the study of labor extraction in the global context.

\section{Consensus Historians}

This chapter will present the literature produced by historians of Russian serfdom who provide the foundational studies of the topic. The work of these historians, whom I call "Consensus" Historians, explain the emergence of serfdom in Muscovy, how it worked and why it endured for centuries in the Russian Empire.

According to the Consensus Historians the free movement of peasants became an increasing concern to the Muscovite state as it consolidated power through war. Over two centuries, restrictions on the movement of peasants gradually shifted from temporary bans to extended prohibitions culminating in the Law Codes of 1649, which permanently 
bound the resident peasants to the land they occupied. The state, according to these historians, deprived peasants of the freedom of movement to ensure a labor force for its servitors, who were largely members of the military and civil service elite, in short, the nobility.

Legally bound to the lands granted by the state to the nobility, formerly free peasants, now serfs, were also legally required to pay for their use of the land they lived on by furnishing either labor or rent to their landlords. The labor due was called barshchina, which was never legally codified but was generally accepted as three days a week. Obrok was the equivalent of barshchina, paid in kind or in cash, and was more common in labor dues in less agriculturally productive regions. This arrangement between the serfs and the nobles provided an economic base of revenue for the nobility.

The Consensus Historians describe the state, in enserfing peasants, as ceding to the estate owners its jurisdiction over the stratum peasants now bonded to the estates. ${ }^{1}$ In fact, the Consensus historians suggest the state willingly converted millions of peasants to the status of serfs because it looked to the nobility for policing the peasants. As a result, according to the Consensus view, the enserfed peasants were left without recourse to legal protection from the state, a position that in practice transformed the serfs' status to that similar to a personal possession of the landlords, and that effectively erased the difference between serfs and slaves. ${ }^{2}$

\footnotetext{
${ }^{1}$ Jerome Blum, Lord and Peasant in Russia from the Ninth to Nineteenth Century (Princeton, N.J.: Princeton University Press, 1961): 422.

${ }^{2}$ Richard Hellie, Enserfment and Military Change in Muscovy (Chicago: University of Chicago Press, 1971): 145.
} 
Gauging the significance of serfdom in Russia, Consensus Historians often view Russia as lagging behind Western Europe in economics and political development, and saw serfdom as a major contributing factor to Russian "backwardness.” Alexander Gerschenkron notably argues that the energy and productivity of the peasantry was diverted from potential economic expansion, and instead directed towards unproductive obligation to the nobility. ${ }^{3}$ Jerome Blum agrees with Gerschenkron that serfdom was an institution that slowed agricultural innovation and inhibited the economic growth potential of imperial Russia. ${ }^{4}$

\section{Revisionist Historians}

Whereas the Consensus authors describe the state's involvement in the affairs of the enserfed peasantry as mainly intervening on the behalf of the landowners, the Revisionist authors highlight the state's continued presence in adjudicating enserfed peasants' obligations to estate owners, and in regulating the relationship between landowners and serfs. The Revisionist's thus challenge the Consensus Historians' view that the state simply gave in with regard to the demands of the landlords and ceased to consider the governance of serfs its responsibility. The Revisionists, to demonstrate the state's continued presence in the jurisdiction of enserfed peasants, point to many examples of state intervention on behalf of the serfs in the serf-landowner relationship.

\footnotetext{
${ }^{3}$ Alexander Gerschenkron, Economic Backwardness in Historical Perspective: A Book of Essays. (Cambridge, MA: Harvard University Press, 1962):

${ }^{4}$ Blum, Lord and Peasant, 612-13.
} 
The Revisionist scholars this thesis will examine include David Moon, Alessandro Stanziani, T.K. Dennison, and Thomas Esper. David Moon describes the Russian state as actively promoting the welfare of the serfs by setting legal expectations for the landowners to provide for their serfs' subsistence during times of famine or bad harvests. A 1734 law required landowners to feed their serfs in times of need and to provide them with seed stock. Successive bad harvests led the state to require landlords to set aside reserve granaries. Another important way that the state involved itself in regulating the institution of serfdom was by protecting the serfs from economic ruin or over-exploitation by landowners. The ultimate sanction from the state was to confiscate the estate of an abusive landlord and to transfer it to a trustee or family member. Between 1834 and 1846, there were 2,838 cases involving the mistreatment of serfs, with 630 convictions. 5

The state, according to Alessandro Stanziani, did not completely abdicate its authority over the serfs and surrender it to the landowners. Between the seventeenth and the nineteenth century, Russian estate owners at times published their own instructions or edicts for the governance of their estates, which were meant to "provide a list of rules in place in a given estate." But, Stanziani states, these instructions had to be enforced by the state or they worked in conjunction with the laws of the state. Allowing estate owners to issue their own edicts and instructions, according to Stanziani, testifies not to the ceding of the tsarist state's authority to govern serfs, "but rather to [its efforts to] decentralize the

\footnotetext{
${ }^{5}$ David Moon, “Reassessing Russian Serfdom,” European History Quarterly 26, no.4 (1996): 504-505.
} 
production and the application of the rules pertaining to it." ${ }^{6}$ Stanziani asserts that, ultimately, the tsarist state had the right to intervene in the affairs of any estate, and had the power to remove a landlord's authority for any reason.

Showing that serfdom in Russia was a more flexible institution than that suggested by Consensus Historians, T.K. Dennison points to private estate instructions that at times worked in conjunction with the existing law of the state to broaden the scope of serfs' economic activity. Dennison studies a set of these instructions from the Voshchazhnikovo estate owned by the Sheremet'ev family. Dennison states that on the whole the detailed and uniform instructions issued by the Sheremet'ev estates' central office of managers and administrators benefitted the serfs. The study demonstrates that estate owners and their serfs often bypassed legal obstacles placed by the state, by way of arrangement that enabled serfs to gain, in the owner's name, access to land, right to property, and participation in credit markets. The instructions and the central managerial administrations of the Sheremet'ev estates provided the serfs with a certain degree of legal recognition outside of the peasant commune, and assisted in establishing contract enforcement for serfs. ${ }^{7}$ By describing some of the laws that the landlords had to work around, sometimes for the benefit of their serfs, as in the case of the Voshchazhnikovo estate, Dennison demonstrates that the state was very much present in the legal dealings that involved serfs in these private estates.

\footnotetext{
${ }^{6}$ Alessandro Stanziani, "Revisiting Russian Serfdom: Bonded Peasants and Market Dynamics, 1600s1800s" International Labor and Working Class History 78, no. 1 (2010): 17.

7 T. K. Dennison, “Did Serfdom Matter? Russian Rural Society, 1750-1860," Historical Research 70, no. 203. (2006): 77.
} 
Consensus authors, in addition to stating the equivalence of slavery (understanding slavery as the ownership of people by individuals) and serfdom in Russia, also generally describe serfs in Russia as poor, and living at subsistence levels, thus reflecting the general economic backwardness of Russia. Thomas Esper rebukes this view in a study of Russian industrial serfs who lived and worked, sometimes for generations, in the Ural region where the metallurgical industry was concentrated. Esper uses the archives for the Demidov industrial operations dating from the 1800s to show that workers' conditions there compared favorably to those of contemporary industrial workers in Western Europe and Great Britain. Using data from an 1850s commission for developing Russia's iron industry, Esper demonstrates that there was a correlation between the degree of prosperity of an industrial enterprise in Russia and the lot of its workers, Esper also shows that many Russian industrial serfs enjoyed a degree of economic stability and a standard of living comparable to their counterparts in the less "backward nations." 8

This chapter will examine the argument of the authors mentioned above, as well as of other Revisionist Historians. The next chapter will offer an evaluation of their persuasiveness.

\section{Serfdom in Serf Memoirs and Other Writings}

This chapter will draw on memoirs and other contemporary accounts to assess how well Consensus and Revisionist interpretations reflect the experience and capture the

\footnotetext{
8 Thomas Esper, "The Condition of the Serf Workers in Russia's Metallurgical Industry, 1800-1861," Journal of Modern History 50, no. 4 (Dec., 1978): 660-679.
} 
meaning of serfdom in Imperial Russia. Fewer than twenty serf memoirs have been published. I will use six of these to shed light on the legal relationship between landowners and their serfs, the role of the state in this relationship, and on the types of legal redress or economic opportunity available to serfs.

This chapter will also include contemporary publications dealing with serfdom, in particular Aleksandr Radishchev's Journey from St. Petersburg to Moscow, a stinging critique of the institution of serfdom which appeared in 1790. Radishchev provided a report on serfdom from the perspective of a nobleman who despised the institution and called for its abolition. Radishchev condemned the exploitation of serfs by estate owners, and highlighted the sale of serfs as among the cruelties of serfdom. In equating the treatment of serfs to that of slaves, Radishchev anticipated a central premise of the Consensus historians, that serfs in Russia differed little from slaves. ${ }^{9}$

The serf accounts I will examine begin chronologically with Nikolai Smirnov's Autobiography, written during the reign of Catherine the Great (1762-1796). It describes a life of relative privilege for a bonded person who suffers through a stifling system of control and punishment for his misdeeds, "Peter O.”, "News from Russia," a long form poem apparently meant to be read by the tsar, referred to as a patriarchal leader who would necessarily wish to offer protection to his subjects, no matter how lowly. The memoir of Aleksandr Nikitenko, Up from Serfdom, documents his six-year struggle to obtain freedom, which he did in 1824, in part thanks to his ability to make friends in high 
places. ${ }^{10}$ Written after emancipation, “The Story of My Life and Wanderings, " by Nikolai Shipov, is the astounding tale of a peasant trader who made multiple attempts to escape serfdom and of self-manumission, who made use of his literacy skills to free himself from bondage. The next memoir is that of Savva Purlevskii, A Life Under Russian Serfdom, who was a successful business trader forced to seek redemption following a falling out with his landlord. ${ }^{11}$ Lastly, the memoir of a serf woman, M.E. Vasilieva, "Notes of A Serf Woman," is a rare work revealing the perspective of a woman and a domestic serf, or dvorovye. ${ }^{12}$

\section{Labor Extraction in the Global Context}

This chapter will discuss historians who study the coerced labor practices that arose between the sixteenth and nineteenth centuries. These historians fall largely into two groups in discussing forced labor. The first group offers interpretations for the expansion of coerced labor and the historical reasons for it. The second group of authors, though not in contention over the findings of the classical historians, offer newer approaches to the study of nineteenth century labor and highlight other types of labor extraction found throughout the competitive world commodity markets. Both groups

\footnotetext{
9 Aleksandr Nikolaevich Radishchev, A Journey from St. Petersburg to Moscow, translated by Leo Weiner (Cambridge, MA: Harvard University Press, 1958).

${ }^{10}$ Aleksandr Nikitenko, Up from Serfdom: My childhood and Youth in Russia 1804-1824, translated by Helen Saltz Jacobson (New Haven, CT: Yale University Press, 2001).

${ }^{11}$ Savva Dmitrievich Purlevskii, A Life under Russian Serfdom: The Memoirs of Savva Dmitrievich Purlevskii, 1800-1868 (Central European University Press, 2005).

12 John Kenneth Mackay, Four Russian serf Narratives (Madison, WI. University of Wisconsin Press, 2009).
} 
share the approach of treating forced labor in this era as integral to the expanding world market and increasing efforts to maximize production and profits.

The two groups differ in that historians in the first group draw a distinct line separating "free" and "unfree" labor, and they tend to be more concerned with the reasons for the rise of such forms of unfree labor as slavery and serfdom, and with the ways labor extraction was enforced, rather than with the other aspects of the day-to-day life of these institutions. Going past explanations for why massive labor forces needed to be tied down beginning in the sixteenth century, the second group, consisting of generally of more recent scholars, finds that in actual practice, the divide between coerced labor and semi-coerced labor or "free" labor was often indistinct. Their view suggests that we focus not just on the forced extraction of labor, but also on the methods and practices implemented to heighten productivity across a range of labor institutions, nominally free and nominally unfree.

In the first group, Peter Kolchin and Jerome Blum, among others, assert a clear distinction between free and unfree labor. Both authors place slavery and serfdom squarely in the category of unfree labor. Kolchin and Blum see the growth of slave labor in the New World and the steady loss of rights among the peasantry in Eastern European lands in conjunction with the growing power the planter and landowning classes in the 
Atlantic World and Eastern Europe, both of which interest groups endeavored to secure the labor they needed, by force, to develop profit-driven agricultural production. ${ }^{13}$

By contrast, scholars such as Alessandro Stanziani and Enrico Dal Lago, and Dale Tomich pose the question of free and unfree labor differently. Tomich describes the meaning of "second slavery/second serfdom" in the context of labor during the nineteenth century. He states that the old slave economies transformed into new commodity production areas in different geographical places, and this transformation to commodity production also brought with it changes to the structure of labor bringing new types of labor to replace traditional ones, but not really changing the power dynamics. Building on this theme of change in labor systems, Stanziani tracks the widespread use, particularly after slavery's abolition, of various forms of contract labor in the colonial world, including indentured servants, tenant farmers, Chinese and Indian coolies, and French engagés. Regarding these kinds of contract labor, theoretically free, Stanziani states that they functioned in reality as a form of coerced labor, given that the laborers could rarely rely on the legal protections their contracts supposedly offered. This meant that, according to Stanziani, for the former slaves who after abolition became contract laborers, there was little difference between their former and post-emancipation statuses, as they continued to be deeply beholden to the planter and landowning elites. ${ }^{14}$

\footnotetext{
${ }^{13}$ Peter Kolchin, Unfree Labor: American Slavery and Russian Serfdom (Cambridge, MA: Harvard University Press, 1987); Jerome Blum, "The Rise of Serfdom in Eastern Europe," American Historical Review 62, no. 4 (1957): 807.

${ }^{14}$ Alessandro Stanziani, "Local Bondage in Global Economies: Servants, Wage Earners, and Indentured Migrants in Nineteenth-Century France, Great Britain, and the Mascarene Islands," Modern Asian Studies 47, no. 4 (2013): 1218-1251. Stanziani, "Introduction: Labour Institutions in a Global Perspective, from the Seventeenth to the Twentieth Century," International Review of Social History 54, no. 3 (2009): 351-358.
} 
Dal Lago looks to the Atlantic plantation systems in the U.S. South, Brazil, and Cuba, and to the landed estate systems in Russia, Spain, and Italy in an era of rapidly growing global commodities market that historians call the era of "second slavery," and "second serfdom." He writes that both systems of labor extraction came to be directed at producing cash crops for export to the world markets placing a new emphasis on exploiting both free and unfree labor, from that of slaves to that of tenant farmers and sharecroppers. Dal Lago observes that in this situation, in regards to labor, it was not the distinction between free, semi-free, and unfree labor that mattered most, but that between which techniques and practices, coercive or inducive, were developed to ensure greater productivity. ${ }^{15}$ This then means that a mixture of coercive and inducive measures applied to a "free" labor force might allow it to be more effectively exploited.

The Consensus authors present serfdom as extraordinary and unique in the nineteenth century world. They claim that the institution itself was a reason for the perception of Russian backwardness in comparison to Western Europe. The historians presented in Chapter IV, along with other voices writing on the subject, will help us understand where serfdom in Imperial Russia fits in the spectrum of different types of labor extraction, from coerced labor to "free" contract labor, that emerged in the era of second slavery and second serfdom.

And, Dale Tomich. "The "Second Slavery": Bonded Labor and the Transformation of the NineteenthCentury World Economy." Critical Readings on Global Slavery, 1326-1349.

${ }^{15}$ Enrico Dal Lago, "Second Slavery, Second Serfdom, and Beyond: The Atlantic Plantation System and the Eastern and Southern European Landed Estate System in Comparative Perspective, 1800-60," Review (Fernanda Braudel Center) 32, no. 4 (2009): 391-420. 


\section{CHAPTER I}

\section{CONSENSUS HISTORIANS}

The gradual process of the enserfment of peasants in Russia began, many historians now agree, around the fifteenth century, coinciding with the centralization, militarization, and territorial expansion of the Muscovite state. Three major historians of peasant enserfment, Evsey D. Domar, Richard Hellie and Jerome Blum, each explained the start and consolidation of serfdom in relation to an aspect of Muscovite expansion and state-building. Domar links serfdom to peasant labor becoming scarcer with the increase of arable land under Muscovite control. Hellie ties enserfment to Muscovite military reforms and the rise of a new group of servitors to the state. Blum, like Hellie, attributes the bonding of peasants to the land to the creation of this servitor group, but, unlike Hellie, focuses instead on the growth of Muscovy into a centralized, absolutist state. ${ }^{16}$ Tracing these historians' arguments and those of other scholars who concur with their interpretations, this chapter will present an account of the development and maintenance of serfdom in Muscovy and Imperial Russia, as well as highlight the implications of these interpretations. This chapter refers to this group of scholars as "Consensus Historians" because their view on serfdom's establishment and its significance remains the Consensus for interpreting serfdom in Russia. The "Revisionists" Chapter II discusses

\footnotetext{
${ }^{16}$ Jerome Blum, Lord and Peasant in Russia from the Ninth to Nineteenth Century (Princeton, N.J.: Princeton University Press, 1961). Evsey D. Domar. Capitalism, Socialism, and Serfdom: Essays. (Cambridge [England]; New York: Cambridge University Press, 1989). Richard Hellie, Enserfment and Military Change in Muscovy (Chicago: University of Chicago Press, 1971).
} 
will challenge the Consensus view not by questioning the process of enserfment that Consensus Historians present, but by critiquing the Consensus Historians' understanding of how serfdom as an institution worked in Russia.

\section{Beginnings}

The binding to land of a significant portion of the peasantry took more than two centuries to complete. As late as the 1570s, according to Hellie, peasants in Muscovy were "still moving about freely." ${ }^{17}$ From the reign of the Muscovite Grand Prince Vasilii II (1425-62) to that of his great-grandson, the first tsar Ivan IV (1530-1584), rapid military expansion fueled by civil wars and wars with Muscovy's western and southern neighbors required the rulers to reward loyal supporters and maintain massive armies, costs that the state was unable to pay for from the tax revenues alone.

The first major restriction on peasant movement was imposed between the 1450s and the end of Vasilii II's reign. The Grand Prince conferred special grants to large landowning monasteries that narrowed the time in the year that the peasants on their land could depart for another landed estate to a two-week span around St. Georges Day. (November 26). These grants, according to Hellie, could be considered "payoff for civilwar support," in addition to resolving war-induced "labor dislocation" in favor of landholders and restoring the "damaged economy by limiting peasant mobility to the period after harvest. ${ }^{18}$ From decrees affecting several monasteries, the St. George's Day restriction became more widely applied in the next decades and attained the status of a

\footnotetext{
${ }^{17}$ Hellie, Enserfment, 5.

${ }^{18}$ Hellie, Enserfment, 81-82, 84.
} 
universal rule with the codification of the Sudebnik (Law Code) of 1497. The Sudebnik specified the two weeks surrounding St. George's Day as the only legal time peasants could leave their landlord, provided that they had paid in full the tax and "rent" obligations they owed the landlord before their departure. Entrenching this limit on mobility, the Sudebnik of 1550 reiterated the St. George's Day rule. Despite their confirmation of St. George's Day limits, these Law Codes did not enserf the peasants, as they were still legally free to move to other estates. ${ }^{19}$

The broadened application and universalization of the St. George's Day rule, Hellie points out, was tied to the creation by Ivan III (1462-1505) of a new type of land tenure for "service land" (pomest'e). ${ }^{20}$ As a result of the need for military servitors, Muscovite rulers from Ivan III onward began to set up new land as pomest'ia (plural of pomest'e) for compensating the state's servitors. In contrast to the inherited estates, called votchiny (singular, votchina), and held by the hereditary nobility, the boyars, who were less dependable, pomest 'ia were non-hereditary land grants the state issued to the servitors on condition of service. According to Blum, the grand princes, in need of reliable servitors but poor in cash, turned the land acquired through military expansion and the confiscation of large votchina estates into parcels distributed to their loyal servitors. This method of defeating the boyars and transferring their lands to loyal state servitors reached an extreme with the institution by Ivan Iv, better known as Ivan the Terrible, of oprichnina, a special territorial district with a separate jurisdiction made up

\footnotetext{
${ }^{19}$ Hellie, Enserfment, 84-89, Blum, Lord and Peasant, 111.

${ }^{20}$ Hellie, Enserfment, 84.
} 
of confiscated votchiny that were redistributed as pomest'e estates to the oprichniki, the tsar's servitors who formed the elite corps of guards notorious for their violence and excesses. $^{21}$

Blum points out that the difference between pomest'ia and votchiny faded away relatively quickly. By the end of the seventeenth century, the two forms of landholding were indistinguishable, as both pomest'ia and votchiny were inherited by the male kin of the estate holder. In recognition of the "de facto fusion of the two forms of landholding," according to Blum, "the legal distinctions between them [were] obliterated by a decree [in] 1714." ${ }^{22}$ Even though pomest'e and vothcina estates eventually became identical legally speaking, initially, the difference between them led to a significant disparity in their ability to attract peasant labor, as the hereditary landholdings, votchiny, were usually wealthier, more centrally located estates with fertile land, while the conditional landholdings, pomest'ia, often comprised of poorer land at the frontiers of Muscovy.

As both territorial expansion and frequent warfare led to labor shortage, the newly minted pomeshchiks (landholders of pomest'ia) competed against votchnniks (landholders of the votchiny) for peasants to move to their estates. By the mid sixteenth century the competition became acute as the success of the Muscovite conquests encouraged peasant migration to the newly acquired regions in the south and southeast. This outward migration movement often favored pomeshchiks, but time and again votchinniks gained

\footnotetext{
${ }^{21}$ Blum, Lord and Peasant, 170. Charles J. Haperin, “Contemporary Russian Perceptions of Ivan IV's Oprichnina," Kritika: Explorations in Russian and Eurasin History 18, no. 1 (Winter 2017): 99-102. 22 Blum, Lord and Peasant, 183. 185.
} 
the upper hand in enticing peasants to their estates by paying off the peasants' debts to their previous landlords.

Peasants were expected to pay for the use of the lands that they resided in, along with taxes to the state as well as meet their obligations to the landlords. This frequently meant that the peasants were unable to pay one or the other in any given year. The later part of the fifteenth century to the mid seventeenth century witnessed the growth of peasant debt to the landlords. Prohibited by various forms of legal and contractual arrangements from leaving their landlord-creditors, heavily indebted peasants, many historians such as Blum believe, in effect found themselves "lifelong peons of their creditors, paying interest by their labor on a debt they could never hope to wipe out by their own efforts." ${ }^{23}$ This indebtedness served to hold the peasants in place. At the same time, it also played into the hands of the landlord competing for the labor of the peasants; richer lords could induce peasants to leave one estate for another by paying their debts off, effectively gaining peasants' productive capacity by taking on their debt obligations.

As competition for peasant labor grew fiercer, estate holders who lost out increasingly pressured the state to legally limit peasant movement. Some landlords also devised their own tactics to discourage peasant departure, such as hiking up the departure fees past the legal maximum, purposely avoiding being available on St; George's Day for receiving the formal notice of departure required by law, and even resorting to physical force, as they "were also accused of beating, torturing, and chaining peasants to prevent

${ }^{23}$ Blum, Lord and Peasant, 244. 
them from leaving" their estates. ${ }^{24}$ For many peasants prevented from departure by landlords and by legal and contractual restrictions, running away became an attractive option.

The number of peasants who fled "reached incredible heights" in the sixteenth century. ${ }^{25}$ Peasant flight was a constant issue for tax collectors as well as small and middle sized pomest'ia. To complicate matters, a legal form of labor poaching, called vyvoz, or exportation, became a common way for large estates to attract labor. The legal vyvoz was the payment by a landlord receiving peasants into his estate of the exit fees and outstanding debts owed by these peasants to the original landlord. Illegal vyvoz was the abduction or kidnapping of peasants. Both legal and illegal forms of "exportation" worked to the great favor of the votchinniks who had more money, land, and other resources than the pomeshchniks, who were often recent servitors and nobility of lesser rank. This became an acute issue for the Muscovite government because it was increasingly dependent on these servitors and the lesser nobility, not only for reducing the boyar influence, but also for military buildup and state centralization. The "middleservice class," as Hellie calls these servitors, was rapidly growing as the Muscovite state consolidated. But peasant flight from their estates left them without the economic support that enabled their military service. ${ }^{26}$

\footnotetext{
${ }^{24}$ Blum, Lord and Peasant, 249

${ }^{25}$ Blum, Lord and Peasant, 251, 255.

${ }^{26}$ Hellie, Enserfment, 93-94.
} 
In response to this problem of peasant flight and vyvoz and labor poaching by land magnates, and thus the declining economic status of the servitors just as the Muscovy state was becoming even more reliant on them, particularly during the arduous Livonian War (1558-1583) fought against Sweden, Poland and Lithuania, the Muscovite government began to repeal the right of peasants to leave their landlord's estate accorded by the St. George's Day rule. ${ }^{27}$ In 1580 , Ivan IV decreed a ban on all peasant movement during that year, and repeated that ban in 1581, making these so-called "forbidden years". At first these bans were viewed as temporary, but these "forbidden years" soon became the norm. According to Blum, "at least half, and probably more, of the decades of the [fifteen] eighties and nineties seemed to have been 'forbidden years,' and from 1603 on every year was declared to be a 'forbidden year'". That these bans were seen as temporary is shown by the rental agreements between renters and landowners of this time, which included stipulations that the renters would, in compliance to edicts imposing "forbidden years," remain on the landlord's lands until the issue of a contrary edict ending the ban on peasant departure. ${ }^{28}$

Despite these attempts to curb peasant movement, major land magnates continued to abduct peasants or bribe them to leave smaller landholders. The first decrees to address this situation were issued in the 1590s under Boris Godunov, brother-in-law of the son of Ivan IV, Theodore I (1584-1598), and the de facto ruler of Muscovy who became tsar following Theodore's death. As Boris, "well known as a friend of the middle service

\footnotetext{
${ }^{27}$ Hellie, Enserfment, 96.

${ }^{28}$ Blum, Lord and Peasant, 254-255.
} 
class," according to Hellie, both favored the servitors and recognized the influence of the upper nobility, which made a "comeback" after Ivan IV's attempt to decimate it, these decrees sought to satisfy both the small landholders and the large magnates. These decrees placed a statute of limitations of five years for the recovery of fugitive and "exported" peasants, which confirmed the right of the original landholders to reclaim the peasants who contravened the departure ban. At the same time the decrees allowed the large magnates to retain the peasants enticed to settle on their estates by placing a fiveyear limit on the original landlord's claim. In 1607, Vasili Shuiskii, who was briefly tsar during the Time of Troubles, a period of civil war, peasant revolt, and foreign invasion that ensued after Tsar Boris's death in 1605, extended the statute of limitations for recovering runaway and exported peasants to fifteen years, in order, Hellie argues, to gain the support of the servitors whose labor force largely dispersed at this time. Though ineffectual, Shuiskii's decree nevertheless fit into the general trend on the early seventeenth century to further restrict peasant mobility by attempting to impose increasingly punitive measures on the peasant fugitives, which accompanied the middle service class's repeated petitions to the government to jettison the statute of limitations on fugitive peasant recovery altogether to make the right of recovery perpetual. ${ }^{29}$ This meant that after the early seventeenth century, peasant renters were on a trajectory to becoming serfs, legally bonded to the land that they resided and worked on.

In 1649 the final nail on the coffin of peasant freedom was nailed shut. As late as 1645, under Mikhail Romanov (1613-1645), who was elected tsar at the end of the Time

${ }^{29}$ Hellie, Enserfment, 105, 108-109. Blum, Lord and Peasant, 257. 
of Troubles, and into the first five years of Mikhail's son, Tsar Aleksei (1645-1676), the servitors were unable to attain the statute of limitation's repeal. But after a massive riot in Moscow in 1648, during which several of the tsar's officials met violent deaths, the Muscovite government sought support from the middle servitors and conceded to their demands concerning peasant mobility. ${ }^{30}$ The Sobornoe Ulozhenie, or Law Code of 1649 codified the long lists of previous edicts into an orderly arrangement. The section pertinent to peasant mobility was Chapter I1, which dealt with fugitive peasants and the landholders rights to reclaim them. It abolished statute of limitations for reclaiming runaway peasant renters, and allowed landlords to deny all the members of a peasant household the freedom of movement. The Ulozhenie granted landlords the right to move peasant families, along with their property and livestock, from one estate to other holdings. The Ulozhenie also deprived the peasants of full ownership of personal property by permitting the landlord to claim all the property of the peasant renter who departed. The Ulozhenie further stripped the peasant renters of legal independence, requiring that their landlord must represent them in court matters of civil dispute or lesser crimes. The Law Code did not give a legal definition of the status of the peasant renter, nor of "his relation to his seignior". As a result, according to Blum, "there were no legal norms to protect the peasant against the will of his lord." The Ulozhenie's provisions on peasant mobility affected a large portion of the Muscovite population. "Peasants comprised of about 90 percent of the Russian population. Nearly three-quarters of the

\footnotetext{
${ }^{30}$ Hellie, Enserfment, 133-134, 137.
} 
total population was finally enserfed by the Ulozhenie." Hellie estimates. ${ }^{31}$ The historical significance of the explanation for the enserfment provided by Domar, Hellie, and Blum, lies in their emphasis on government action, contrary to many earlier interpretations that attributed serfdom in Russia to spontaneous processes involving peasant indebtedness or long-time residency that came to be viewed as obligation to stay in a fixed location. The Muscovite "agricultural structure" had for centuries three prominent elements, abundant "free land", peasants who were free to move, and landholders who were "non-working" because their primary function was state service, Domar writes. As "any two [of these elements] not never all three can exist simultaneously," he continues, the resolution of this untenable situation "will depend on ... political factors- government measures." 32 The series of the government edicts curtailing peasant movement that culminated in the 1649 Ulozhenie highlights the critical place of political considerations and government actions in the enserfment of the peasant renters.

\section{How Serfdom Worked: "Consensus" View}

The 1649 Ulozhenie did not spell out the legal standing of the peasant renters or that of their relationship to the landlords, as its provisions were directed at prohibiting peasant movement. But Consensus historians like Domar, Hellie, and Blum, writing in the 1960 s and 1970s, are persuaded that after 1649 the enserfed peasants' legal status was similar to that of slaves, who were the personal property of their landlords. Although government action was required to enserf these peasants, Consensus historians argue that

\footnotetext{
${ }^{31}$ Blum, Lord and Peasant, 262-265. Hellie, Enserfment, 145-146.

32 Domar, The Causes of Slavery or Serfdom, 227-228. Hellie, Enserfment, 1-18.
} 
with their enserfment the government in effect abdicated its function to govern and juridically oversee them, leaving the enserfed to the whims of their landlords, and thereby turning peasant renters into slaves.

Domar considers "agricultural serfdom" and "slavery" as terms that can be "used here [in the Russian case] interchangeably," and regards serfs as "owned" by the landlords. For Hellie, while recognizing that "sixteenth-century Russian law did not equate the peasant and the slave, and in fact even equated the wealthy peasant with the syn boiaskii [member of the petty nobility]," the state efforts to limit peasant mobility from the early seventeenth-century onward finally led to "a nearly complete identification of peasants with slaves by the government," which saw "both [as] equally the property of their lords." Although government action was crucial for enserfing peasants, these historians concur that after 1649 , the enserfed peasant was left without state protection "against the will of his lord," as Blum argues. ${ }^{33}$ This view of the near equivalence of serfdom to slavery differed from that of the turn-of-the-twentieth century historian, Mikhail Vladimirskii-Budanov, and others, which assert that the government after 1649 continued to consider peasant renters the state's subjects, not landholders' property. ${ }^{34}$ The interpretation of the non-equivalence of serfdom and slavery is picked up by and lies at the core of the argument of the Revisionist historians Chapter II explores. Below, this

\footnotetext{
${ }^{33}$ Domar. Evsey, The Causes of slavery or serfdom, 225, 232. Hellie, Enserfment, 116-117. Blum, Lord and Peasant, 265.

${ }^{34}$ Nicholas V. Riasanovsky and Mark D. Steinberg, A History of Russia, $8^{\text {th }}$ Edition (New York: Oxford University Press, 2011), 184.
} 
chapter presents the Consensus historians' understanding of how serfdom in Russia operated.

Income from pomest'e and votchina estates came from the rent paid to the landlord by peasant renters, and later serfs, for the land they used, often in one of two ways: labor corvée or labor dues, called barshchina, or payments in cash or kind, called obrok,. Some landlords exacted a mixture of both. In the fifteenth century, barshchina was generally set at one day of labor per week. This work consisted of cultivating the landlord's lands, as well as upkeep and maintenance of the estate. Over time the pressure to increase rent in the form of barshchina heightened. During the late sixteenth and early seventeenth centuries, barshchina was generally expected to consist of three days of work per week from the peasants. After Peter I (1682-1725) introduced the soul tax (also called the head, or poll tax) in 1724, a tax that fell on male tax-payers, largely peasants, free and enserfed, the barshchina system of payment became widespread, especially in the Central Agricultural region of the Russian Empire. During the early Imperial era, which began in 1721 when Peter I was proclaimed Emperor (Imperator) of Russia, a new emphasis on agricultural production led many landlords to expect greater output from the serfs, and possibly to rely more on barshchina. Likely reflecting the views of the social critics of that time, Consensus historians believe that eighteenth-century landholders more and more saw their estates as producers of commodities meant for market commerce and extravagant consumption, rather than for basic economic needs. Through the eighteenth century, Consensus historians assert, following the example of some large estates and anecdotal evidence, much of the agricultural output produced by the estates 
was consumed by the landlord's households residing in the urban areas. Some of the estates had as many as a thousand retainers who each year collected cartloads of provisions produced on the estates and directed them to the landlords' manors. ${ }^{35}$

Despite gaining an important economic victory in 1649, numerous landholders became increasingly financially insolvent, due often to the customary practice of partible inheritance that decreased the size of their estates from one generation to the next. By the eighteenth century, most landholders "had such limited means," according to Blum, that they were constantly in debt. Indebtedness was also common even among the richest magnates who managed to preserve the size of their holdings and wealth through primogeniture, though for different reasons. Eighteenth and nineteenth century Russian nobles, after Peter I forced them to give up Muscovite ways and adopt European behavior, began to desire goods such as Western European dress and baubles, and living way above their means, frequently found themselves in a cash crunch. Count N.P. Sheremet'ev, for example, owed an astronomical sum of 2,018,839 rubles in 1800 . His son and heir, D.N. Sheremet'ev owed to creditors $6,000,000$ rubles in $1859 .{ }^{36}$ To get more income "in the feudal agrarian structure" that Emil Niederhauser believes characterized the Russian agricultural economy, landlords turned "primarily [to] increasing the exploitation of serfs," and to increasingly sell the surplus goods they produced on the market. ${ }^{37}$

\footnotetext{
35 Blum, Lord and Peasant, 390.

36 Blum, Lord and Peasant, 377-379.

${ }^{37}$ Emil Niederhauser, The Emancipation of the Serfs in Eastern Europe. (New York, NY: Columbia University Press, 2004). 180.
} 
Serfs on the obrok were often those who earned cash from non-agricultural work, and the Consensus authors agree that in the main they were better off than serfs on barshchina. Landowners in the Central Agricultural district, also known as the blackearth region, where land was fertile, tended to demand barshchina payment. Those in the northern provinces, where the soil was poor, often favored obrok. This was a reflection of the regional economic specialization brought about by the economic expansion of the eighteenth century. Serfs paying obrok usually engaged in kustar, that is, artisanal and craft production. Kustar products were in demand throughout the empire, from the coarse, cheap wares peasants brought to village markets, to luxury articles such as silk and objects made of gold and silver. Serfs who profited from kustar production preferred to pay service obligation to their landlords in obrok. According to Blum, kustar production made up and important portion of the Russian Empire's manufactured goods before the mechanization of factories. And according to Niederhauser, "[i]n the 13 central non-black earth provinces $47,23 \%$ of serfs owed money services, and $30.29 \%$ owed only robot services, while $22.49 \%$ owed both types". Landlords who saw that obrok payment would generate more cash, but still depended on barshchina for maintaining their estate or putting grain on the market, would demand both forms of service obligation from serfs. $^{38}$

With regard to the question of who had jurisdiction over the enserfed peasants, and what kind of control landlords exercised over serfs, Consensus authors describe the Muscovite and later the Imperial government as ceding the state's jurisdiction over the

\footnotetext{
${ }^{38}$ Blum, Lord and Peasant, 302-304. And, Niederhauser, The Emancipation of the Serfs. 178.
} 
vast population of enserfed peasants to the estate holders. They argue that the government, effectively turned over to the nobility, as estate holders, the judicial authority to govern peasants on its land, as well as the legal right to the exploitation of these peasants' labor. After seventeenth-century peasant rebellions marked by the Times of Troubles (1598-1613), and the Stenka Razin uprising, (1670-1671), Hellie states, a common interest to defend themselves and the state against the peasants cemented the upper and lower nobility. Thus, although the 1649 Law Code resulted from the rivalry between the upper nobility (the magnates) and the lower gentry (the servitors), after a century of peasant uprisings, according to Hellie, it served to defend the nobility as a whole, and "created a closer identity of interests between the magnates running the government and the middle service class.” Both groups, Hellie writes, were deeply threatened by "the rebels' proclaimed goals...to attain freedom and to kill first the boyars and then all the lords plus military officers." ${ }^{39}$ The state, in turn, dependent on both the upper and lower gentry to crush the rebellions and restore stability, was unlikely to make any concessions to the enserfed peasants as any attempt to reduce the gentry's "caste privileges", Hellie argues, "might have toppled the government."40

In Jerome Blum's view, “the state withdrew almost entirely from supervision and interference in the relationship between lord and peasant," and "allowed serf owners to gain nearly unlimited powers over the people they owned." According to Blum, "by the last part of the eighteenth century the Russian serf was scarcely distinguishable from a

\footnotetext{
${ }^{39}$ Hellie, Enserfment, 247

${ }^{40}$ Hellie, Enserfment, 257.
} 
chattel slave. ${ }^{41}$ Consensus Historians observe that the 1649 Law Code restricted free movement of the peasants without providing any protections against arbitrary acts of illwilled landlords, or legal recourse in the case of abuses. One type of abuse Consensus Historians believe was common in the eighteenth century, a prosperous era for the nobility that followed the perils of the century before, was the buying, selling, and even mortgaging of serfs, which leads the writers to equate such transactions involving serfs with the contemporary slave markets the United States. Blum admits that the 1649 Ulozhenie prohibited "the sale of peasants without land," meaning that one landlord's claim on an enserfed peasant could only be transferred to another landlord when the estate the peasants lived on was sold to that landlord. But he argues that "this prohibition had been widely disregarded," as there were repeated bans against the sale of the enserfed. Peter I, for example, issued an edict in 1721 censuring the violation of the prohibition. But Peter did not fully enforce the ban, and allowed for serfs to be sold "in cases of need." Blum further contends, shifting from looking at serfdom to military recruitment, that Peter in other decrees not only permitted but also encouraged "the sale of human beings...by allowing persons subject to military draft to buy substitutes." In 1771, Catherine II decreed that "the spectacle of human beings on the [auction] block...be banned." But this edict was largely ignored, such that in 1792, according to Blum, she amended this decree to ban, not the sale of serfs, "but...the use of the hammer by the auctioneer." The publication of the Svod Zakonov (Collection of Laws) under Nicholas I (1825-1855) in 1832, the first systemization of the laws since 1649, reminded

\footnotetext{
${ }^{41}$ Blum, Lord and Peasant, 422.
} 
landholders of their responsibilities to the serfs on their land. The relevant part of the code, volume nine, aimed to curb some of the more egregious behavior of the part of the landlords. But this code and the subsequent Penal code of 1845 did not clarify the prohibition of trading in serfs without the sale of the land, even though, as Blum concedes, these laws did somewhat improve the conditions of serfs. ${ }^{42}$ Generally, the Consensus Historians believe, the government's lack of interest in protecting the serfs and the inadequacies of the legal codes meant that serfs were left to the will of the landlords, as that they could not expect the government to intervene on their behalf.

Blum states that "besides acquiescing to the reduction of the seignorial peasants (serfs) to human chattels to be bought and sold, the government sanctioned a wide expansion in the judicial and police powers of the serfowners. ${ }^{\circ 3}$ The Consensus authors argue that the government did so to free itself from the onerous work of policing the countryside. The 1649 Law Code did not prevent enserfed peasants from following the time-honored custom of petitioning the sovereigns to seek redress against abuse. Catherine II, however, eliminated this right to appeal to the government for direct intervention in an $u k a z$ (edict) issued in 1767. The $u k a z$, which followed a tour of the country by the empress, during which "she had been besieged with petitions, [and after which] decided that this nuisance must end," forbade serfs from presenting directly to the sovereign "petitions against their masters," Blum writes. Violation of this decree was

\footnotetext{
${ }^{42}$ Blum, Lord and Peasant, 424-436.
}

${ }^{43}$ Blum. Lord and Peasant, 429. 
made a criminal act "punish[able] by beating and forced labor, according to Niederhauser. ${ }^{44}$

Niederhauser, like other Consensus Historians, presents a view of a government that was deliberately not involved in the relationship between landlords and serfs. He writes that the laws that forbade serfs the freedom of movement, that gave them no legal recourse to resist being sold, and forbade them from acquiring property all resulted from the decision of the state to not intervene on behalf of serfs. Niederhauser argues that when the state did intervene, it was to help the landlords, as in the case when estate holders were given the right in 1822 to banish disobedient serfs or serfs they disliked to Siberia. ${ }^{45}$

Some laws did set limits on the landlords' right to punish disobedient serfs. For example, certain criminal offenses were outside of the jurisdiction of the landlords, such as murder. When landholders tried peasants on their estates for such offenses, or when they handed out excessive or illegal punishments, they could be given severe penalties. Though such legislation demarcated the extent of the landlords' judicial powers, Blum states that during the eighteenth century these boundaries were largely obliterated by loosely phrased legislation. Some limits were introduced. especially in the 1840s and 1850s, such as rules forbidding landlords from administering overly severe punishment. Thus, beating with a rod was limited to 40 blows, and beating with a cudgel to 15 , while

\footnotetext{
${ }^{44}$ Blum, Lord and Peasant, 440. Niederhauser, Emancipation, 181. "An act of 1767 provided that if a serf lodged a complaint against his landlord, he was to be punished by beating and forced labor."

${ }^{45}$ Niederhauser, Emancipation, 181.
} 
incarceration in the estate jails was not to exceed two months. If a serf violated the laws to such an extent that more severe punishment was justified, the landlord was required to hand over the serf to government authorities. However, Consensus authors such as Blum insist, as the enforcement of these rules and obligations rested with the landlords themselves, it was highly unlikely for the government to intercede except in the case of "the most extreme and flagrant violations" by the landlord. But, Blum states "even then, investigation was difficult," Because, after all, serfs did not have the right to enter complaints about their masters, for the law demanded 'silent obedience' from them. ${ }^{46}$ Consensus Historians in general point to the state's absence in the serf-landlord relationship, since serfs could not rely on the government for protection against abuses by landlords. Some historians, such as Steven L. Hoch, go further, arguing that when the state's representatives did interact with serfs, they did so in exploitative ways, extorting serfs and taking bribes. Using the estate records from the first half of the nineteenth century for a serf village called Petrovskoe in Tambov province, Hoch presents examples that include the payment of twenty rubles to a rural official to avoid the obligation of quartering government troops on the estate. When two counterfeit bills were discovered in the villagers' tax payment, the villagers gave fifty rubles to the government treasurer to smooth over any misunderstandings. In 1811, upon noticing errors entered into a tax census of that year, the village serfs paid over 300 rubles "so that the matter will not be discovered by provincial officials. ${ }^{{ }^{47}}$ Hoch shows that the serfs in Petrovskoe dealt with

\footnotetext{
${ }^{46}$ Blum, Lord and Peasant, 435-432.

${ }^{47}$ Steven L. Hoch, Serfdom and Social Control in Russia: Petrovskoe, a Village in Tambov, (Chicago: University of Chicago Press, 1989). 181.
} 
government authorities by paying off officials in order to lighten the burdens placed on them as a result of government bureaucratic mismanagement.

Although the Consensus authors emphasize that the government did not commonly intervene on the behalf of the millions of bound peasants, and that state intervention usually benefitted the nobility, occasionally, some among these authors acknowledge that the state did intervene in favor of the enserfed peasants. Hellie demonstrates immediately following the Ulozhenie of 1649, the Muscovite government issued a series of decrees that made exceptions to the Law Code. A 1653 decree, reiterated in 1656, said that serfs who fled to Ukraine prior to the Ulozhenie were not to be retrieved. Another decree, in 1675, stipulated that no former peasant or slave who enlisted in the new regiments of the expanding Muscovite army could be forced to return to their landlords. Yet another decree, issued in 1684, "permitted all peasants who had fled to Moscow to remain there. ${ }^{48}$ An example of government action that showed the state to be not fully committed to punishing those landlords who harbored fugitive peasants was its cancellation, in 1652, of the fines imposed on magnates found to have done that, thereby reversing the Ulozhenie's intent to apply financial sanctions on lords who illegally kept runaway serfs. Thus, from Muscovy onward, although Consensus authors argue that if there were laws that in some way favored serfs, they were rarely enforced. Hellie's examples here show that these laws both did exist and were enforced.

\footnotetext{
${ }^{48} \mathrm{Hellie}$, Enserfment, 250-251.
} 
Chapter II will elaborate on the place of the state as presented by the Revisionist Historians.

\section{Serfdom's Legacy: The "Consensus" View}

Discussing serfdom in the nineteenth century, an era in which contemporaries began to perceive Russia as lagging behind Western Europe in economics and political development, historians and thinkers began to question whether serfdom was a profitable or efficient labor regime. Until recently, many scholars found serfdom to be incompatible with the market economy, urbanization and industrialization that characterized Western Europe in this period. This school of historians associated the presence of serfdom in the Russian Empire, with Russia's "backwardness", relative to the industrializing and democratizing West. Deeply influenced by this view, the Consensus authors see serfdom as a root cause of Russian backwardness. A major proponent of the link between serfdom and backwardness is the economic historian Alexander Gerschenkron. Explaining Russia's "economic backwardness" compared to the industrialized West, Gerschenkron states in a study published in 1962 that "the main reason for the abysmal economic backwardness of Russia was the preservation of serfdom until the emancipation of 1861 ." Gerschenkron attributes the historical transformation of Russia from the small duchy of Moscow to an immense empire in a matter of several centuries to rapid military expansion and frequent wars with its neighbors. Hellie echoes and builds on this view. In need of a modern military, Gerschenkron argues, the state assumed the role of the primary agent of economic progress to meet this need. Propelled by the necessity of military innovation, this type economic progress was not continuous, according to 
Gerschenkron, as it sped up when military conflicts intensified, and slowed when military needs diminished, leading to a pattern of rapid spurts of economic development followed by prolonged stagnation. At the same time, this mode of economic growth placed a large burden on the people. Binding peasants to land was one of the measures the state took to exact sacrifices from them. ${ }^{49}$

Speaking of Peter I, who imported Western technology and began building a higher education system aligned with that of Western Europe, Gerschenkron insists that the emperor's attempt at Westernizing Russia only made Russia less like the West. Holding Peter's reforms responsible for "placing the trammels of serfdom on the Russian peasantry," and making serfdom a central institution of Russian society propped up by the state, Gerschenkron writes that these reforms "must be understood as the obverse side of the process of Westernization." Gerschenkron notes that serfdom in Russia began as an obligation peasants owed to the state, to enable the nobility's service to the same state. But when serfdom became just an obligation peasants owed directly to the nobility, it was detached from Russia's economic development, as it now lost its broader purpose and served only the nobility. In fact, by then serfdom only worked to retard this development, according to Gerschenkron. ${ }^{50}$ In addition, Gerschenkron points out, during the eighteenth century enserfed peasants' condition worsened. Under Catherine II, he believes, the spread of serfdom across the new territories annexed by the empress led to the increasing severity of the nobility's exploitation of the serfs and the rapid deterioration of their

\footnotetext{
${ }^{49}$ Alexander Gerschenkron, Economic Backwardness in Historical Perspective: A Book of Essays, (Cambridge, MA: Harvard University Press, 1962) 17-19.

50 Gerschenkron, Economic Backwardness, 20.
} 
juridical position. Gerschenkron admits that there was "development ... in certain branches of the textile industry," but emphasizes that "progress was almost imperceptible in other fields, particularly in the iron industry, as the output of which hardly kept up with the increase in population," and that "the relative economic backwardness of the country increased not inconsiderably during the first half of the [eighteenth] century." This overall lack of progress, according to Gerschenkron, was the basis for the persistence of Russia's backwardness throughout the nineteenth century, even after the abolition of serfdom by Alexander II in $1861 .^{51}$

Sharing Gerschenkron's view of the shortage of capital and the poor condition of enserfed peasants as critical factors leading to backwardness, Blum writes that "lack of capital, the low productivity of serf labor, and the nature of the structure of the entire 'feudal' economy, blocked the introduction of technical improvements and efficient organization." ${ }^{, 52}$ Although he acknowledges that many advances made in trade and industry from Peter I to Alexander II, Blum focuses on the lack of innovation in the area of agriculture, the predominant economic activity of the empire. According to Blum, "the techniques of tillage employed by the peasants, whether serfs on privately owned lands or the half-free peasants who lived on state land, were virtually unchanged from what they had been in the middle-ages." In Blum's view, serfs on noble estates were less inclined to innovate than their contemporaries in Western Europe and the United States, while the landlord's themselves were only interested in squeezing revenues in cash and kind from

${ }^{51}$ Gerschenkron, Economic Backwardness, 153-155..

52 Blum, Lord and Peasant, 612-613. 
their estates. Often the noble estate holders, according to Blum, "instead using the money they borrowed [from the government] to improve their properties and so increase their incomes, they spent it on consumption goods." 53

Like many historians who study Russia, Consensus Historians such as Blum and Hellie find factors besides serfdom as contributing to Russia's "backwardness". For example, Blum sees the "fantastic inadequacy" of the empire's system of communication and transportation as a massive barrier to the growth of trade, and thus Russia's backwardness. ${ }^{54}$ On the whole, however, Consensus Historians stress the importance of serfdom as a prevalent institution for extracting agricultural labor, and the successive worsening of the enserfed peasants' plight, as the primary reason for the stagnation of Russian Economic development. The Russian Empire in their view, had kept the institution of bondage to land far longer than its Western contemporaries, thereby holding back social and economic progress, since the presence of serfs, being in essence slaves, contradicted the ideals of modernity and progress. The next chapter will examine historians who, presenting a different and more recent perspective on serfdom in Russia, challenge the Consensus Historians' conclusions regarding the enserfed peasants' condition, legal standing, as well as the relationship between labor extraction based on serfdom and the perceived economic backwardness of Russia.

\footnotetext{
53 Blum, Lord and Peasant, 327-329.

${ }^{54}$ Blum, Lord and Peasant, 282-284. A recent study by John Randolph, however, suggests that the road and communications system in both Muscovy and the Russian Empire may not be as dire as Blum asserts. See Randolph, "Communication and Obligation: The Postal System of the Russian Empire, 1700-1850," in Information and Empire: Mechanisms of Communication in Russia, 1600-1850, ed. Simon Franklin and Katherine Bowers (Cambridge, UK: Open Book Publishers, 2017), 155-184.
} 


\section{CHAPTER II}

\section{REVISIONIST HISTORIANS}

Consensus Historians argue that the Muscovite and the Imperial Russian government using the peasants as an instrument in its maneuverings for consolidating state power with collaborations of the noble servitors, ended up binding them to the lands granted to the nobility, and ceding the state's jurisdiction over them to the landlords. More recent historians, however, find the state's role with regard to the enserfed peasants to be more nuanced than what the Consensus Historian's assert. The state, they argue, at times acted to maintain the institution of serfdom, and at times to undermine it. This chapter refers to those historians as "Revisionists" and examines the arguments of representative members among them, such as Roger Bartlett, David Moon, Steven L. Hoch and Alessandro Stanziani. ${ }^{55}$ Revisionist Historians challenge the depiction presented by Consensus scholars regarding how serfdom worked. They suggest that the economic arrangement between peasants and their landlords was more varied and flexible than the Consensus authors allow, and the state, rather than absent, was often active in intervening on behalf of the enserfed peasants.

\section{State Regulations after 1649}

\footnotetext{
${ }^{55}$ Roger Bartlett, "Serfdom and State Power in Imperial Russia," European History Quarterly 33, no. 1 (2003): 29-64. David Moon, "Reassessing Russian Serfdom," European History Quarterly 26, no.4 (1996): 484-526. Steven L. Hoch, Serfdom and Social Control in Russia, Alessandro Stanziani, "Revisiting Russian Serfdom: Bonded Peasants and Market Dynamics, 1600s-1800s," International Labor and Working Class History 78, no. 1 (2010): 12-27.
} 
To the Revisionist Historians, serfdom was not a monolithic institution that was uniform across the empire, nor did it remain unchanged from inception to abolition. Agreeing with the Consensus Historians that the Ulozhenie of 1649 did not spell out the legal status of the enserfed, Bartlett nevertheless points out that the lack of legislative definition meant that peasant-landlord relations could differ considerably across the empire, making serfdom a flexible institution, and that these relations were often tempered by customary practices and the self-interest of the landlords, "as it was in not in the landowners' interest to harm their peasants or harm them economically." ${ }^{56}$ Bartlett, and other Revisionist Historians as well, also note that the state, particularly from the Imperial era onward, had frequently issued decrees and regulations that affected the relationships between the state and the enserfed peasants.

Under Peter I (1682-1725), the Muscovite-era distinction between the two types of landholding, the hereditary votchina, held by the upper nobility, the boyars, and the pomest'ia, granted to servitors for their service, ceased to exist. Both became known simply as pomest'ia (estates), with their holders referred to as pomeshchiki (estate owners). All pomest'ia were by then hereditary and landholding became severed from the noble's service obligation. In part to force the nobility back into service, Peter I created the Table of Ranks in 1722, a system of promotion in the bureaucracy and compensation by ranking that tied the preservation of the nobility status to state service, as well as allowing nonnobles to enter state service and obtain noble status. But, forcing the nobility back into state service, Peter did not reestablish the connection between landholding and

\footnotetext{
${ }^{56}$ Bartlett, "Serfdom and State power,". 31.
} 
state service, since he recompensed state service not with grants of land, but with monetary salaries ${ }^{57}$ The disconnection of land grant from service compensation should have led to the question of whether continued enserfment of peasants could still be justified. In the early 1700s, however, according to Bartlett, serfdom, like slavery, was "still taken for granted in European élite and ruling circles." It is therefore not surprising that Peter did not abolish serfdom, as it would have been contrary to his general policy of subordinating all subjects of the state to state service. Peter's extensive social engineering and economic, political, and military reforms affected all groups in society. His measures on the peasantry created new categories of "peasants" while also offering some protection for enserfed peasants from excessive exploitation by landlords, but peasants under Peter I bore the brunt of the expanding military needs of the state: they provided the recruits for the military whose term of service was lifelong, and were subject to the "soul tax", also called the poll tax or head tax, introduced in 1718 and levied on all male adults of the lower ranks of the Russian Empire's subjects, the majority of whom were peasants. Likewise under Peter I, a passport system was implemented to control peasant movement and regulate labor flow, Passports were used by those seeking employment away from their home village or registered estate, and required for labor that was both servile and "free". According to Bartlett, "the petty trader, the hired agricultural labourer or industrial worker was often a landlord's serf on otkhod (travelling to find work), and bearing a passport from his master." 58

\footnotetext{
57 Moon, "Reassessing Russian Serfdom," 489. Bartlett, "Serfdom and State power," 36.

${ }^{58}$ Bartlett, "Serfdom and State Power," 31.
} 
Following Peter I, decades of struggle ensued between the state and the nobility over the obligation of state service. In 1762, definitively reversing his grandfather's insistence on obligating nobles to perform state service, Peter III (1762) proclaimed the "emancipation of the nobility." Thereby abolishing this obligation and making state service voluntary for nobles. ${ }^{59}$ To the leading historian of Imperial Russia around the turn of the century Vasilii Kliuchevskii, Peter III's emancipation proclamation did away explicitly with the fundamental assumption of the Muscovite and early Imperial society, that everyone served. Kliuchevskii believed that the abolition of compulsory gentry service should have been in fairness immediately followed by another abolition, that of peasant service to the noble landlords. Peasant uprisings after 1762 appeared to have reflected the sense of injustice Kliuchevskii described, as these uprisings frequently upheld demands for the peasant freedom that was supposed to have followed the gentry's emancipation. ${ }^{60}$

Catherine II (1762-1796), like Peter I, deepened the state's reliance on the servile system. At the same time, the position of the servile peasantry became an issue of public concern in the Russian Empire. Different from the Petrine era, now, "across Europe, abolitionist tendencies were stirring: moral opposition to black slavery and white serfdom, combined with the new philanthropy of the Enlightenment combined to prompt concern for the welfare and improvement of the lower classes." even though "public opinion in Europe as in Russia was still [largely] pro-slavery." ${ }^{\prime 61}$ Bartlett describes

\footnotetext{
59 Moon, "Reassessing Russian Serfdom," 499.

${ }^{60}$ Riasanovsky and Steinberg, A History of Russia, 248.

${ }^{61}$ Bartlett, "Serfdom and State Power," 38-39.
} 
Catherine II as "genuinely disapprov[ing] of serfdom," and credits her for initiating public discussion on the "peasant question". The ferocity and unusual success of the Pugachev uprising (1773-75), a Cossack and peasant rebellion led by a Cossack commander, Emilian Pugachev, which threatened to take St. Petersburg, pushed the empress to rely on the nobility support and abandon efforts to weaken or do away with serfdom, as serfdom had become by her reign the mainstay of noble wealth. After the rebellion, Bartlett writes, "she made no more public gestures towards the peasant question." ${ }^{62}$ In 1785 , aiming to strengthen the nobility's corporate status, the empress issued the Charter to the Nobility, which granted new rights and confirmed the abolition of the gentry service decreed by Peter I.

Catherine's successor, Paul I (1796-1801), Bartlett notes, viewed serfdom as a positive institution, and believed that the serfs were better off under the protection of the nobility than if they were left free but unprotected and exposed to rapacious officials and outsiders. But Paul also issued a law limiting enserfed peasants' labor obligation, obrok, to no more than three days a week, "presumably to protect serfs against excessive exploitation." According to Evsey D. Domar and Mark J. Machina, who call this "Paul's Law." 63

Alexander I (1801-1825) who succeeded Paul, was not a supporter of serfdom, but he shied away from abolishing the institution. Wishing to end serfdom but favoring a

\footnotetext{
62 Bartlett, "Serfdom and State Power," 38-39.

${ }^{63}$ Bartlett, "Serfdom and State Power," 39-40. Evsey D. Domar and Mark J. Machina, "On the profitability of Russian Serfdom," Journal of Economic History, no. 4 (December 1984): 929.
} 
voluntary scheme, as Jerome Blum observes in his assessment of the emperor. Alexander issued the "Free Agriculturalist's Law" of 1803, which gave enserfed peasants the right to purchase their freedom from landlords, and the landlords the right to emancipate their serfs, while also ensuring that the emancipated peasant would obtain land. Peasants freed in this way were enrolled in the estate category (referring to the official registry of recognized social statuses) of "free agriculturalist," or "free farmers," and be considered as state peasants, meaning free peasants. Only a tiny percentage of serfs were affected by this edict. As of 1858, three years before Alexander II (1855-1881) issued the Imperial edict that abolished serfdom, about 1.5 percent of the total population of enserfed male peasants, along with their families, were freed by use of this law. Alexander and his ministers and advisors' efforts to weaken serfdom were nonetheless adopted and pushed even further by two of the three of the empire's Baltic provinces, Estland and Livland (also known as Estonia and Livonia), whose diets decided to free the provinces' serfs soon after $1803 .{ }^{64}$ But they implemented emancipation without land, which might have taught the Imperial government the lesson that the emancipation of serfs in the central parts of the empire would have to be accompanied by land for the newly freed peasants.

For Nicolas I, (1825-1855), whose central concern was social stability, serfdom was an evil whose remedy might cause more harm than good. He was recorded as stating in a declaration to the Council of State in 1842 that "No doubt that serfdom in its present condition in our country is an evil, palpable and obvious to all; but to attack it now would

\footnotetext{
${ }^{64}$ Bartlett, "Serfdom and State Power," 40. Blum, Lord and Peasant, 540-542.
} 
be something still more harmful." Not legislating new codes regarding serfdom, Nicholas limited himself to confirming Paul's Law by incorporating it into the 1832 Law Code, and to reasserting Alexander's "Free Agriculturalists Law," allowing landlords to emancipate peasants on their own. Nevertheless, it was under Nicholas I that "significant numbers of estates" were in effect confiscated by the state as a sanction against landlords in the wake of peasant disorders. ${ }^{65}$ It was also under Nicholas that the number of peasants emancipated by various methods significantly increased, as a later section in this chapter will show.

Enserfed peasants in the parts of the Russian Empire outside the Baltic provinces obtained their emancipation in 1861, as decreed by Alexander II. Blum calls it "the last great triumph of royal absolutism over the nobility," a commentary that reflects his view of the empire as unchangingly absolutist from the Muscovite era to the 1860s. But other historians see emancipation as the work of those whom W.B. Lincoln calls "enlightened bureaucrats," government ministers and advisors committed to transforming Russian society who gained pivotal influence under Nicholas I and paved the way for the sweeping reforms that Alexander II initiated within the first decade of his reign. ${ }^{66}$ Both commentaries acknowledge the centrality of the state in enacting the abolition of serfdom, as this institution did not fade away in its own in Western Europe.

65 Bartlett, "Serfdom and State Power," 40.

66 Jerome Allen, The End of the Old Order in Rural Europe (Princeton, NJ: Princeton University Press, 1978), 383. W.B. Lincoln, In the Vanguard of Reform: Russia's Enlightened Bureaucrat, 1825-1861. (DeKalb, IL: Northern Illinois University Press, 1982). Both quoted by Moon, “Reassessing Russian Serfdom," 512. 


\section{How Serfdom Worked: The Revisionist View}

Revisionist Historians offer a reassessment of the institution that shows that Russian serfs did not experience only remorseless exploitation, coercion and degradation. David Moon explains that neither the state nor the nobility was interested in extracting ruinous demands from the serfs, for both groups depended on them for support. After the implementation of the "poll tax" in 1718, Moon states that the government became more attentive to the needs of the peasants and their protection, as without the tax income from taxing peasants the state would basically be without funds to operate the empire. From the mid-eighteenth century both the state and the landowners who saw themselves as "enlightened seigniors" began to define their relationship with the peasants in "moral as well as economic terms," even if, according to Moon, at bottom their intention "was to make the incomes from the peasantry more secure. ${ }^{67}$

Enserfed peasants themselves at times saw that being bound to the land was not entirely negative. As Steven L. Hoch observes, if peasants' subsistence was to come from the land they lived on, then "being tied to the land ... implied an entitlement to the land." Unlike large numbers of rural inhabitants in many other European countries, "Russian serfs were not landless labourers who depended for their subsistence on the uncertainty of finding employment on someone else's land," Moon points out. He notes that the mir (peasant commune) "partitioned, and periodically repartitioned, parcels of arable lands

\footnotetext{
${ }^{67}$ Moon, "Reassessing Russian Serfdom," 501. The term "enlightened seigniors" and its description, quoted by Moon, are from H.E. Melton, "Enlightened Seigniorialism and its Dilemmas in Serf Russia, 1750 1830," Journal of Modern History 62 (1990): 675-708.
} 
between its member households," in order "to ensure that each peasant household had sufficient land to support itself and meet its share of the obligations which the commune as a whole owed" to the landlord and the state. The redistribution of peasant communal lands was a customary practice that became widespread by the eighteenth century. It was supported not only by the state, and landowners, but also the peasant "elites," meaning the elders and the leading male heads of households of the commune. "The system of noble landownership and communal peasant landholding," according to Moon, was to some degree supported by the serfs themselves. ${ }^{68}$

The case of the noble landlord, I.D. Yakushkin, the future Decembrist rebel, reflects peasants' sense of entitlement to the land they inhabited. In 1819, Yakushkin announced to his serfs on his estate to Zhukovo, in Smolensk province, that he wished to free them and offer the land to them for rent, but the offer was refused because the peasants considered the land already theirs. Moon writes, "they asked [Yakushkin] whether the land 'which we now possess [Vladeem]' would 'belong' [prinadlezhat] to them. On being told that it belonged to Yakushkin but that they could rent it from him they replied that they would carry on 'in the old way', and added, 'We are yours, but the land is ours." In other words, given the choice between the two statuses, the peasants of Zhukovo preferred remaining enserfed to becoming "free" tenant farmers. ${ }^{69}$

\footnotetext{
${ }^{68}$ Moon, "Reassessing Russian Serfdom," 502. Moon quotes from Steven L. Hoch, Serfdom and Social Control in Russia: Petrovskoe, a Village in Tambov. 94-95, 107-108, 124.

${ }^{69}$ Moon, "Reassessing Russian Serfdom," 502.
} 
Enserfed peasants labored on land and also engaged in a variety of other occupations. The well-known examples mentioned by Bartlett of serf entrepreneurs who amassed fortunes, and who, using their landlord's name to purchase property and bypass legal prohibitions, were themselves holders of estates inhabited by serfs, exhibit how varied enserfed peasants' economic existence could be. The enserfed owed to their landlords dues that were paid in the form of barshchina (labor obligation) or obrok (in money or kind). Serfs on the barshchina were far less mobile and led lives more closely regulated by estate bailiffs. But, as Bartlett states, often it was in the financial interests of the landowners to permit their peasants to pay in obrok so the peasants could take up trade, handicraft production, and other occupations. The common use of obrok to allow a measure of labor mobility can at times be seen from the hiring during harvest at one landlord's estate of peasants on obrok from another estate to supplement the labor of the landlord's own barshchina peasants. ${ }^{70}$

T.K. Dennison's study of the Voshchazhnikovo estate in the Rostov district of Yaroslavl' province, about 300 kilometers (190 miles) north-west of Moscow and 600 kilometers (380 miles) south-west of St. Petersburg, provides an example of the kinds of economic activities enserfed peasants could undertake. Voshchazhnikovo was the largest of the thirty villages that comprised the estate, which took its name from the village. Because Voshchazhnikovo belonged to the Sheremet'ev family, who had over thirty estates that were spread across seventeen provinces, and who was among Imperial Russia's richest and most prominent noble families, this example is not typical of the

\footnotetext{
${ }^{70}$ Bartlett, "Serfdom and State Power," 31.
} 
empire, as Dennison acknowledges, though it was fairly average compared to the other of the Sheremet'evs' estates, being 'neither the largest nor the smallest, neither the wealthiest nor the poorest," and having "no particular economic specialism [specialization] on the estate" that would distinguish it from the other of the family's estates. This example is nevertheless revealing since it shows how far serfs experiences could diverge from that commonly depicted by Consensus Historians. ${ }^{71}$

Using estate documents dating from 1750 to 1860 , right up to the year before emancipation, Dennison describes that serf on the Voshchazhnikovo estate paid the obrok (dues in cash or kind) rather than the barshchina (dues in labor). Less than ten percent of the serfs on the estate relied on agricultural work alone. Many of the serfs engaged in a wide range of other economic activities. Some leased their communal land allotments to others and took up wage-paying employment. Some serfs hired laborers to work their allotment while they themselves traded or worked in various rural industries, at times doing well enough to own small manufactories, for example tanneries and distilleries, and to hire workers for these manufactories. Still others found work as migrant laborers in Moscow, St. Petersburg, or urban centers further away. ${ }^{72}$

Serfs were legally forbidden from purchasing land until 1848, when state law under Nicholas I removed this prohibition and permitted enserfed peasants to hold land in their own name, but before then, such peasants did manage to buy and sell land, often

\footnotetext{
${ }^{71}$ T.K. Dennison, "Did Serfdom Matter? Russian Rural Society, 1750-1860," Historical Research 70, no. 203. (2006): 75.

72 Dennison, "Did Serfdom Matter?," 75-77.
} 
with the aid of estate landlords who were willing to bend the rules. Sometimes landlords did so for the payments the received for lending their name to serfs purchasing land. Estate records at Voshchazhnikovo show that the estate's peasants, identified in these records as servants, agricultural workers, and unmarried women, were in possession of land they purchased. The downside of such extra-legal land deals was that enserfed peasant landholders ran the risk that their landlords could simply seize these holdings, whose titles bore the landlord's name. But, as Dennison points out, the high volume of such extra-legal transactions involving serfs at Voshchazhnikovo perhaps shows that the danger of such seizures was rather small on the estate. ${ }^{73}$

Serfs on the Voshchazhnikovo estate conducted credit transactions as well. These transactions connected serfs giving or receiving credit to other estate serfs, serfs from other estates, and often to free peasants, merchants and even landowners. According to Dennison, the credit markets in which the Voshchazhnikovo serfs participated were not merely local to the estate, but were instead "extensive regional networks." In all, whatever occupation they followed, Dennison notes, "a surprisingly large number of serfs at Voshchazhnikovo ... achieve[d] a considerable degree of wealth." Around $70 \%$ of the estate's enserfed peasants "possessed taxable assets worth at least 500 rubles," at a time when the estate's annual obrok dues were set at a range between 15 and 70 rubles. $^{74}$

Thomas Esper provides another example of an estate inhabited by enserfed peasants whose material condition did not match the Consensus Historians' description of

\footnotetext{
73 Dennison, “Did Serfdom Matter?," 75-76, 79, 83.

74 Dennison, "Did Serfdom Matter?," 75-76, 81. Emphasis added in quoted phrase.
} 
serf existence, in this case and industrial estate consisting of metallurgical factories in the mineral-rich Ural region. This estate, Nizhnii Tagil, was inhabited by enserfed peasants who had by the first half of the nineteenth century, after generations' employment at the factories, became in effect what Esper calls "a hereditary industrial labor force." The Nizhnii Tagil industrial estate was founded in 1725, beneficiary of Peter I's efforts to industrialize the Russian Empire. To provide the empire's nascent industrialists labor for their manufactories, Peter I signed a decree in 1721 allowing manufacturers to purchase villages inhabited by peasants, who were to work in these new estate owners' factories. By this decree Peter invalidated the prohibition against nonnoble purchase of inhabited land and estates, in favor of manufacturers of humble background like Nikita Demidov, who built copper-smelting works and other plants "with his very own money," according to the historian Evgenii V. Anisimov. The villages purchased for industrial plants, such as the Nizhnii Tagil estate held by the Demidov family, were known as "villages attached to works," and their inhabitants, as "assigned peasants," "industrial peasants," or "industrial serfs." 75

By the mid-nineteenth century, Nizhnii Tagil comprised of nine factories and six mines, "an enormous enterprise that straddled the Urals [mountain range]," and covered 2,700 square miles, according to Esper. Its mines extracted iron, copper, gold, platinum, and malachite in large quantities. In 1859, the estate produced raw iron worth nearly 3

\footnotetext{
75 Thomas Esper, "The Condition of the Serf Workers in Russia's Metallurgical Industry, 1800-1861," Journal of Modern History 50, no. 4 (Dec., 1978): 670. Evgenii V. Anisimov, The Reforms of Peter the Great: Progress through Coercion in Russia, trans. John T. Alexander (Armonk, NY: M.E. Sharpe, 1993): 178., Blum, Lord and Peasant, 313.
} 
million silver rubles, and counted 10,000 workers, about one-tenth of the Ural region's metallurgical workers. ${ }^{76}$ One of the best-known industrial estates, Nizhnii Tagil drew favorable comments from contemporaries, but, as Esper notes, condemnation from many later observers and historians, since these historians, like the Consensus authors, see industrial serfs as emblematic of the worst abuse dispensed by the institution of serfdom. Mikhail Turgan-Baranovskii, preeminent Russian historian active in the early twentieth century, claimed, as conveyed in Esper's words, "that the industrial serfs had to endure a life of total slavery, working for mere subsistence from childhood to old age under the threat of harsh punishments." Soviet historian F.S. Gorovoi writes in 1961 of the abuses these serfs were subjected to, "the barbarous tyranny of the factory administration, the torturing of workers, low rates of pay and the long work day." U.S. scholar William Blackwell, referring in a 1968 study to the horrors he presumed were experienced by these serfs, insists that compared to those endured by early industrial workers elsewhere in Europe, "conditions [in the Ural factories were] made more onerous by a few more purely Russian methods of exploitation and punishments." Reinhardt Bendix, German émigré sociologist and later U.S. scholar, deems in 1959 that "the doctrines of autocratic rule assum[ing] the total depravity of workers and serfs" permeated industrial serfdom, and that the industrial estates "punished [workers] severely if they failed in their obligations," as these estates "relied upon the omnipresence of fear and coercion to make workers and serfs act as they ought to act." ${ }^{, 77}$ Finally, one of the Consensus authors

\footnotetext{
${ }^{76}$ Esper, "The Condition of the Serf Workers," 672-673.

77 As cited and quoted by Esper, "The Conditions of the Serf Workers," 660-662.
} 
Chapter I discusses, Jerome Blum, writes of the Demidovs" "sinister reputation," and of their punishment of industrial serfs "attempts by some of their employees in the early nineteenth century to present petitions to the tsar ... by shooting would-be petitioners, or by throwing them alive into the blast furnaces." ${ }^{98}$

Esper states that there is in fact "very little" evidence to support these scholars" "bleak picture of industrial serfdom in the Urals." He notes that previous studies of the serfs, especially those by Soviet historians, derived their conclusions from tallying worker "disturbances" (volneniia), a term that was very broadly defined to mean "anything from acts of armed violence to refusal to obey instructions." These scholars identified between 47 and 111 "disturbances" for the years 1820-1860, but neglected to notice that worker unrest and disturbances in the Urals factories generally involved only those Esper calls "auxiliary workers," who were unskilled, did largely menial work, and belonged neither to the category of industrial laborers nor that of "peasants of the usual sort." Skilled workers, those in the shops or at the furnaces, Esper writes, "rarely participated in disturbances." $" 79$

The industrial serfs at Nizhnii Tagil were actually paid to work at these plants. Though they were technically serfs, by the mid-nineteenth century the workers there were at least three generations removed from their origin as peasants, and much closer to what could be referred to as free industrial labor while their material condition compared more favorably to that of factory workers in other countries at that time, as Esper suggests. The

\footnotetext{
78 Blum, Jerome. Lord and Peasant. P. 313. Quoted in Esper, "The Conditions of the Serf Workers," 662.

${ }^{79}$ Esper, "The Condition of the Serf Workers," 663-664.
} 
enserfed workers and their families at Nizhnii Tagil, in addition to wages received land allotments provided by the estate management to grow food and raise animals for their own use, and obtained from the estate other necessities free of cost, such as wood for construction and fuel. This way of providing for the workers appears to be common in the Urals industrial estates. Esper writes, "Because the worker's families in the Urals provided, through their own labor and independently of their industrial employment, a significant portion of their food and housing, one could assume that in this respect their lives were more secure that those of the laboring people in the west, who were dependent on the receipt of money wages," to meet their subsistence needs. ${ }^{80}$ Real money wages were higher in Western Europe for the average worker than in the Urals. For example, as calculated by the French sociologist, socialist, and metallurgical specialist Frédéric Le Play, who wrote a detailed study and eyewitness account of Nizhnii Tagil, the average wage earned by an English ironworker in the 1840s was 1,803 francs annually, as opposed to the equivalent of 499 francs earned in a year by industrial serfs in the Ural complexes. But the factory management in the Ural complexes bore expenses that their counterparts in the West did not. For example, the Urals estates paid the taxes of each male serf, regardless of whether or not he was gainfully employed, and the additional fees to the government for exempting their workers from military conscription. The Urals estates also paid for social services such as old age and disability pensions, and free health care. By the mid-1850s, 42 percent of the estate's overhead costs went to providing for these social expenses at Nizhnii Tagil. This was on the high end, as other

\footnotetext{
${ }^{80}$ Esper, "The Condition of the Serf Workers," 666-667..
} 
estates paid less for social services: for instance at the Neviansk complex it was 27 percent of its overhead costs, and at Alapaevsk, 16 percent. But these estates included social expenses as a given. ${ }^{81}$

Visiting the industrial complexes of the Urals in the 1840s, the renowned British geologist Roderick I. Murchison was deeply impressed by both the privately held estates, like Nizhnii Tagil, and the state-run operations. He wrote, "the Russian miners ... have thinned the forests, erected commodious and often splendid buildings," and the resident population there was "more advanced in knowledge than any" elsewhere in the Russian Empire. Under "the highly flourishing condition of these centres of industry, each more populous and thriving than many towns" in the empire, he continued, lived "many thousand industrious workmen, whose houses and essential comforts we have seldom seen surpassed in the manufacturing towns of Europe." Other contemporary visitors have noted that the Urals industrial complexes included, apart from schools for the workers' children and hospitals that provided free care, also a public library, a museum, and a botanical garden. One traveler in 1848 described Nizhnii Tagil's hospital as "excellent," and soon after, the estate-town had two hospitals and two nurseries. Le Play observed that, as Esper phrased it, the empire's "best health and educational services for the workingmen were to be found at the [Demidov's] metallurgical plants. ${ }^{82}$

The evidence Esper finds indicates that the industrial serfs of the Urals, particularly the shop workers, were no more exploited than were free workers in Western

\footnotetext{
${ }^{81}$ Esper, "The Condition of the Serf Workers," 667, 677-678.

${ }^{82}$ Esper, "The Condition of the Serf Workers," 668-669, 674.
} 
Europe, and that in some respects, their lives were more placid and stable. Like the enserfed peasants at the Sheremet'ev estate of Voshchazhnikovo, the workers at Nizhnii Tagil, Esper finds, could hold property, although unlike the Voshchazhnikovo peasants they were prohibited from selling to those outside the estate or mortgaging their property. With regard to the social services workers; obtained from the industrial estates, many workers in the Ural factories "so valued this security that some of them received their emancipation in 1861 with dismay," Esper writes, for they considered these services their "rights." Some went so far as to petition the state "for a return to the old serf system," according to Esper. For their part, the estate management could dispense with providing social guarantees after emancipation. Esper points out that the Nizhnii Serginsk factory complex, also in the Urals, reported in 1863 a net savings of 170,000 rubles compared to pre-emancipation years. That is, even though after 1861 the wages paid to the complexes' workers increased to 52,000 rubles a year, "the ending of serfdom" had eliminated around 223,000 rubles in annual expenses that covered, along with the taxes and fees paid on behalf of the male workers, the social guarantees the workers and their families had come to expect. ${ }^{83}$ Emancipation in the case of many Ural workers turned out to mean the severance of the reciprocal obligations between the enserfed and the estate landlords. If the workers were now "free" to move and seek employment elsewhere, the estate owners were now "free" to not provide social services.

Jurisdiction: Who Governed Enserfed Peasants?

\footnotetext{
${ }^{83}$ Esper, "The Condition of the Serf Workers"” 671-672, 676.
} 
Consensus Historians, as shown in Chapter I, believe that the state after acting to enserf peasants no longer had a role in governing the peasants, leaving them entirely to the control and "whims" of their landlords, that both the Muscovite and the Imperial state did rely on the nobility to govern the state's vast territories at the local level, reflected in Nicholas I's view of the landlords as "100,000 rural police chiefs" who would, as Bartlett states, served as "a substitute for local government" in the countryside, seems to confirm this belief. ${ }^{84}$ But attempting to establish local government based on extending the nobility's prominent local position did not always mean allowing gentry landlords unrestrained domination over their estates and locality. More often, even as gentry domination of the countryside prevailed, the state's reliance on the nobles for local administration also meant delegating responsibility and decentralizing the state's purview for such critical purposes as collecting taxes, providing for empire-wide communication networks, and ensuring disaster relief in times of hardship caused by natural catastrophes.

Revisionist authors indicate that the enserfed peasants mostly "ate relatively well," Moon writes, and lived in "relative, if tenuous prosperity," as Hoch shows for the peasants of Petrovskoe in the Tambov province, about 280 miles southeast of Moscow. But the precariousness of their life would be evident in the years of bad harvest and famine. In 1734, under Empress Anne (1730-1740), a state law demanded private estates provide relief during such times of food shortage, the state often lowered grain prices to ensure for the peasants. A series of failed harvests in the early nineteenth century led the state to insist that landlords provide famine relief for the peasants and set up reserve

\footnotetext{
${ }^{84}$ Bartlett, Serfdom and State Power, 48.
} 
granaries. During the famine of 1833-1834, under Nicholas I, the central authority in Moscow and the provincial government together issued 22 million paper rubles to ease the supply of money and to alleviate the disaster in the rural areas. ${ }^{85}$

With regard to local governance, the state permitted very large estates, such as the Voshchazhnikovo estate held by the Sheremet'evs, to create a regularized administrative system for these estates through issuing their own decrees (prikazy) and statutes, called "instructions" (instriuktsii). Dating back to the late eighteenth century, the decrees and instructions for Voshchazhnikovo dealt with a broad range of activities. They included the assessment and collection of taxes and dues, "rights ... to [such] communal resources" as forests and meadows, regulations for building new structures like homes and barns, the registration of the peasants" "estate" (soslovie, referring to social status, not land), rules for hiring or renting property to outsiders, and fines and punishment for breaking the Voshchazhnikovo estate's policies. When a situation not foreseen by the decrees and instructions arose, Dennison writes, the estate bailiffs drew on "a sort precedence system" by referring to policies and principles established in other estates. Contrary to the Consensus authors' assertion that landlords' treatment of their peasants was guided by “whim,” Dennison notes that Voshchazhnikovo's manger-administrators “evidently tried to avoid arbitrary forbidding" when deciding on peasant requests or infractions. ${ }^{86}$

\footnotetext{
85 Moon, "Reassessing Russian Serfdom," 504-505. Hoch, Serfdom and Social Control in Russia, 64.

${ }^{86}$ Dennison, “Did Serfdom Matter?," 78-79.
} 
Commenting on the purposes of these estate-issued instructions and edicts, (nakazy), Alessandro Stanziani notes that imperial Russian state law recognized these estate edicts as having the "force of law." According to Stanziani, this recognition, contradicting the Consensus Historians' view of the governments' absence in the affairs of the noble estates, "testified to the tsarist state's determination not to abdicate its authority inside the estates," and its aim "to decentralize the production and the application of the rules" that followed principles upheld by and codified in state law. These principles included, Stanziani writes, pushing nobles "to run their estates in a more rational way" and us[e] more advanced farming techniques," as well as to devise rules directed at "reducing social tensions," especially after the Pugachev revolt in 1773-1775, and "preserving [the state's] pool of soldiers. ${ }^{87}$

At Nizhnii Tagil, which in 1840 had a managerial-administrative staff of 555 members, "most of whom were themselves serfs," according to Esper, the state made its presence known through the factory inspectorate commission it dispatched to the Urals industrial estate. The commission's reports from the 1850s rated private industrial estate such as Nizhnii Tagil with regard to the quantity of iron processed, the volume of fuel and ore reserves, the enterprises' "economic and technological condition," and how well they maintained their labor force. Although these reports had few details concerning working conditions, as Esper notes, they nonetheless reflected a ranking of preferences for how estates should treat their workers. The ranking had at the top "complete

\footnotetext{
${ }^{87}$ Alessandro Stanziani, "Revisiting Russian Serfdom: Bonded Peasants and Market Dynamics, 1600s1800s," International labor and Working Class History 78, no. 1 (2010): 17.
} 
paternalism," followed by "complete satisfaction" in the way "people are maintained," down to "maintained well" and "maintained justly" for the middling ratings, and "maintained unsatisfactorily" and "unjustly" for the lowest ratings. ${ }^{88}$

The presence of the state in the private estates such as those of the Sheremet'evs, the Demidovs, and the Gagarins, whose Petrovskoe holding Hoch examines, was often felt indirectly, by the need to skirt official regulations. The private estates tended to bend rules to permit, for instance, the buying and selling of property by the enserfed, which was prohibited by government law. But these practices of rule-bending remained extralegal, and were not recognized outside the particular estates that allowed them. Within these estates, however, enserfed peasants frequently could and did make use of the estates' judicial provisions to assert their claims, litigating at times against the peasant communal heads, at times against the estates bailiffs. ${ }^{89}$ The informal system provided by these estates let some of the estates' enserfed peasants prosper in extralegal activities, but they came at a cost. These estates' "extralegal social conventions," Dennison writes, quoting Hernando de Soto's term, also left the peasants open to demands for extra payment premiums for engaging in officially sanctioned transactions, or "bribery," for example in the form of higher property down payments, hefty fees for the estates' "power of attorney contracts" (doverennost', i.e. certifications) for the use of the landlord's name,

\footnotetext{
88 Esper, "The Condition of the Serf Workers," 664-666, 673.

${ }^{89}$ Dennison, “Did Serfdom Matter?," 80, 81-82.
} 
commission to the landlord for lending his name to this certification, or outright payments to state officials for looking the other way. ${ }^{90}$

More directly, though perhaps relatively infrequently, the state's presence could be felt, according to Dennison, "when officials in St. Petersburg showed that they were willing to rule against local elites when provided with evidence of wrongdoing." In exchange for conferring the "force of law' on estate-issued regulations, the central government expected estate owners to bear primary responsibility for good order on their lands. "The lords' authority could be withdrawn by the tsar at any moment," according to Stanziani, for "abus[ing] their power," or for illegally holding the title to an estate, such as in the case of nonnobles claiming ownership of inhabited lands, a privilege that was by law only granted to the nobility for the greater part of the pre-emancipation years. The most severe sanction against landlords found to have neglected or excessively punished their serfs was to confiscate their estates and place the estates under the stewardship of a family member or trustees appointed by the local nobility. Catherine II gave the threat of this sanction "greater force" in 1775, around the time of the Pugachev rebellion that galvanized enormous contingents of discontented enserfed peasants. During the reign of Nicholas I, "significant numbers of estates were taken into trusteeship (opeka)," according to Moon. Citing documents from the Ministry of Justice, Moon states that between 1834 and 1845, the number of landlords tried for the ill-treatment of their serfs was 2,838 , of whom 630 were found guilty. The state was not always successful at

\footnotetext{
${ }^{90}$ Dennison, "Did Serfdom Matter?," 83. Dennison quotes from H. de Soto, The Mystery of Capital: Why Capitalism Triumphs in the West and Fails Everywhere Else (2006) Ch. 6. Dennison, "Did Serfdom matter?," 83, 84-86.
} 
protecting the serfs from their landlords' exploitation, Moon writes, as the enforcement of the state law relied on the nobles themselves, who dominated the rural and provincial courts, to rule against their own. However, the threat of the state intervention in estate affairs served to offer some restraint against abusive landlords, and reinforced expectations for how "good masters" should behave. These expectations amounted to, Moon observes, what E.P. Thompson calls a "moral economy" based in large part on the enserfed peasants' "subsistence ethic."91

Finally, the state's presence was felt in the ways enserfed peasants could change the legal registration of their "estate" status (soslovie; referring to social position and occupation, not land) or that of their children from "enserfed peasant" to other estate categories. This could occur through marriage. Dennison finds that a number of the "poorer serfs" at the Voshchazhnikovo estate strove to have their children marry "members of a higher social category (soslovie)," that is, of a higher-ranking estate, such as merchants or townspeople, and were willing to pay exorbitant fees to obtain their landlord's permission for marrying outside their estate status. The requests for permission mostly involved daughters. Dennison does not specify whether the estate (soslovie) registration of the serf brides would change to that of her husband after marriage, but presumably in either case the offspring of these marriages would take the estate of their father, making it possible for a serf family to have its descendants leave behind the legal

\footnotetext{
91 Dennison, “Did Serfdom Matter?,” 80-81. Stanziani, “Revisiting Russian Serfdom,” 17. Moon, "Reassessing Russian Serfdom," 505-506. Moon quotes E.P. Thompson, "The Moral Economy of the English Crowd in the Eighteenth Century", Past and Present, 50 (1971): 76-136.
} 
status of the enserfed in a generation or two. Reviewing the law codes of Imperial Russia issued after the 1830s, Stanziani mentions that the widows of serfs could change their legal estate status if they "married someone belonging to another legal category.",92

Other channels for changing the estate status of the enserfed include voluntary emancipation by landlords, who were legally permitted to do so after the 1803 Law of the Free Agriculturalists. Peasants who were transferred in violation of the law by their landlords to lands held by nonnoble or nonnoble corporate entities would be removed from the landlords, reascribed to the estate status of "state peasants,' and became "free" because state peasants did not owe dues in labor or in kind to their landlord, the state. In 1841, for instance, according to Stanziani, large numbers of enserfed peasants saw their status change to "state peasant" because their landlords illegally transferred them to ecclesiastical estates. Perhaps one of the more common ways for enserfed peasants to change their status was through military service. The army, in Stanziani's view, was a "powerful source" of change with regard to serfs' legal status. Prior to emancipation, conscription took into the army mostly serfs who had no choice, as conscripts served for twenty to twenty-five years, after which they were usually unable to return to their home village, their place having been taken by others. Thus, upon completing his military

\footnotetext{
92 Dennison, “Did Serfdom Matter?," 85-86. Alessandro Stanziani, "Russian Serfdom, A Reappraisal," $A b$ Imperio 2014, no.2: (2013): 83-84. 38. In contrast to France, for instance, where estate classification was formally abolished in 1789, the Russian Empire retained until 1917 the estate system for assigning legal rights and privileges according to social status. That in English the word estate refers to two different things, legal status, (soslovie) and landed property (pomest'e), is potentially confusing, which explains why the authors discussed in this chapter avoid using the term "estate" to refer to soslovie even though that is the standard translation. See Gregory Freeze, "The Soslovie (Estate) Paradigm and Russian Social History," American Historical Review, 91, no.1 (February) 1986): 11-36.
} 
service, the conscript would be reclassified as a state peasant or as raznochinets (literally, a person of nonnoble rank"), an estate category that would allow the former serf to become part of the urban population. By these various means, close to half a million enserfed peasants changed their legal status between 1833 and 1858, according to Steven L. Hoch and Wilson Augustine. More boldly, taking into account the changing legal and administrative acts that affected the enserfed, Stanziani estimates that "almost half the Russian serfs had been emancipated from their obligations to private owners in the decades before the official abolition of serfdom" in 1861. He further posits that "Russian emancipation was already in progress before [1861], promoted through administrative and political measures with a minor contribution from the judicial system." On the eve of emancipation, 52 million of the empire's population were classified as belonging to the peasant estate. ${ }^{93}$ Of these, 20 million were "enserfed peasants" by estate status, or 38 percent. Among the 32 million peasants who were "free," or 62 percent, quite possibly a good portion were former serfs who only recently effected a change in their legal status.

\section{Serfdom's Legacy: Backwardness?}

The picture of serfdom presented by Revisionist Historians differs greatly from that offered by Consensus scholars. Not surprisingly, the Revisionist view of the historical significance of serfdom in Russia diverges substantially from that of the Consensus view. Consensus Historians believe that serfdom caused the empire to be backward, implicitly holding up Western Europe economic and political development as

93 Stanziani, “Russian Serfdom: A Reappraisal," 93. Riasanovsky and Steinberg, A History of Russia, 368. 
the standard for comparison. Revisionist Historians, challenging what it means to be "backward" and using the lens of contemporary ideals, turn instead to look at how well or poorly the bondage of peasants to land served the state and empire.

Bartlett argues that not only did serfdom not hamper the expansion and international standing of the Russian Empire, but, by providing the Petrine state "the money (taxes) and rank-and-file manpower which supported both the fisc and the armed forces," it was also a contributing factor to the success of the empire. Catherine II, Bartlett continues, promoted public welfare, education, and administrative order, and achieved immense military and territorial gain, "without major changes in the status of the servile peasantry." Under Alexander I, the Russian army, made up of peasant conscripts, defeated the Napoleonic military machine, catapulting the Russian Empire to the top of the European powers. ${ }^{94}$

Contrary to the image of unrelieved social and economic degradation Consensus scholars offer, Revisionist Historians, referring to archival estate documents, point to significant numbers of enserfed peasants who were prosperous and flourishing, particularly in the first half of the nineteenth century. Revisionist disagree on the cost of this prosperity, however. Dennison observes that the bribes and extra fees the enserfed had to pay to circumvent state laws and estate rules amounted to a "confiscatory pattern." These costs, Dennison states, "obviously diminished the incentive to engage in the sort of entrepreneurial initiatives that played such an important role in the agricultural and

\footnotetext{
${ }^{94}$ Bartlett, "Serfdom and State Power," 36-39.
} 
industrial revolutions in early modern England," and served to curtail the successes of the serfs. ${ }^{95}$ Moon shows, on the other hand, how the customary practices, state laws, and estate rules that might have been seen by some peasants as overly rigid and had to be circumvented, might have been taken for granted by others as the basis of social guarantees and protections.

Moon demonstrates that serfs were not itinerant workers without access to land, as was so commonly the case in Western Europe by the early twentieth century. He describes the Russian peasant commune (mir), whose workings ran against property ownership, as a defense against exploitation, as it regularly re-parceled land to give every serf family access to productive lands, and shared the tax burden in an equitable fashion to relieve the destitute of financial destruction. ${ }^{96}$

With regard to the efficacy of serfdom as an economic institution, the view of the Soviet historian M.N. Pokrovskii is representative of the Consensus position. He argues that, in the words of Evsey D. Domar and Mark J. Machina, "serfdom had become unprofitable for the masters," and thus the reason for the Russian state to free the serfs in 1861. Testing Prokrovskii's assertion, Domar and Machina's analysis of price levels, demographic trends, and land availability, concludes however, that "we have not found that the profitability of Russian serfdom before 1861 was threatened" by the nineteenthcentury trends often seen as undermining the profit from serf labor, such as the rise of grain prices, population growth, and the increasing use of the obrok (dues in money and

\footnotetext{
95 Dennison, “Did Serfdom Matter?," 89.

96 Moon, "Reassessing Russian Serfdom," 502.
} 
kind) system, which allowed for greater labor mobility and took peasants away from their landlords' estates and home villages. ${ }^{97}$

With regard to policy and jurisdiction, as Stanziani and Dennison show, rather than arbitrary and capricious, both the state authorities and the estate managements attempted to govern rationally, with the estates building on customary practices to devise a set of rules and "instructions" to govern estates, and to fill in the gaps left by state law. Stanziani suggests, in fact, that the combined jurisdiction of the government and the estates had allowed for a gradual erosion of serfdom, as increasing numbers of those ascribed to the estate category of "enserfed peasants" found ways to register in another category. But the shock of the "Crimean debacle," as Bartlett calls Russia's defeat in the Crimean War (1853-1856) that forced the Russian Empire off "the pinnacle of Great Power status," left little room for a gradual process and propelled "the issue of serfdom to the top of the Imperial agenda," according to Bartlett. ${ }^{98}$ Soon after, signaled by Alexander II's 1861 edict of emancipation, the Imperial state moved to undertake a profound transformation of the empire, showing the full force of its presence in peasant and gentry society.

The Revisionist view of serfdom challenges earlier assumptions about the institution of serfdom. Chapter III shows that the experience of serfs, as told by the peasants themselves, varied widely and the institution was far from monolithic.

\footnotetext{
97 Domar, Machina, "On the profitability of Russian Serfdom," 919, 949.

98 Bartlett, "Serfdom and State Power," 40,47,53.
} 


\section{CHAPTER III}

\section{SERF MEMOIRS AND OTHER WRITINGS}

This chapter focuses on the memoirs and the autobiographical accounts of enserfed peasants in the Russian Empire, of which about twenty are known to exist. This chapter examines, listed here in rough chronological order, the writings of Nikolai Smirnov (1767-1800), an unidentified serf who called himself "Peter O.”; Aleksandr Nikitenko (1804-1877): Nikolai Shipov (1802-?); Saava Dmitrievich Purlevskii (1800ca.1868); and M.E. Vasilieva, (dates unknown), who told of her life as a serf girl. ${ }^{99}$

To set these accounts of enserfed peasants in the greater context of historiographical interpretations, this chapter will begin by discussing Aleksandr Radishchev's A Journey from St. Petersburg to Moscow (1790), a stinging critique of the institution of serfdom. An exposé of the horrors of serf life, it was the earliest literary work to deal solely with enserfed peasants. Radishchev provided a report on serfdom from the perspective of a nobleman who despised the institution and called for its abolition. He condemned the exploitation of serfs by estate owners, and highlighted the buying and selling of serfs as among the cruelties of serfdom. ${ }^{100}$ In equating the treatment

99 John MacKay, ed., Four Russian Serf Narratives, (Madison, WI: University of Wisconsin Press, 2009). Savva Dmitrievich Purlevskii, A Life under Russian Serfdom: The Memoirs of Savva Dmitrievich Purlevskii, 1800-1868, translated by Boris B. Gorshkov (Central European University Press, 2005). Aleksandr Nikitenko, Up from Serfdom: My childhood and Youth in Russia 1804-1824, translated by Helen Saltz Jacobson (New Haven, CT: Yale University Press, 2001).

${ }^{100}$ Aleksandr Nikolaevich Radishchev, A Journey from St. Petersburg to Moscow, translated by Leo Weiner (Cambridge, MA: Harvard University Press, 1958). 190. 
of serfs to that of slaves, Radishchev anticipated a central premise of the Consensus Historians, that serfs in Russia differed little from slaves. ${ }^{101}$

The influence that "A Journey from St. Petersburg to Moscow" had on the historiographical interpretation of the institution of serfdom can hardly be overstated. Highlighting Journey's critiques of serfdom, this chapter shows the links between the description of serfdom that appeared in Radishchev's book and that of the Consensus authors.

\section{Radishchev's Journey}

Published anonymously and with Radishchev's own funds, the Journey came out in 1790 , the same year that his civil service to the state granted him the promotion to the position of Chief of Custom House at the busy and highly important port of St.

Petersburg. Although Radishchev submitted the manuscript to the censor prior to publication, the version he printed included additional material that the censors approved without having read it. Despite the ploy of anonymity, the author's identity was discovered without difficulty, given the small circle of writers and intellectuals at this time. Responding to his work, Catherine II wrote ten pages of closely spaced text of detailing her impressions and counter arguments. According to her secretary Alekandr Khrapovitsky, "[the empress] was graciously pleased to say that he [Radishchev] was a rebel, worse than Pugachev," the Cossack leader of a devastating rebellion fifteen years before whom Catherine put to death. ${ }^{102}$ Radishchev was condemned to death, although

\footnotetext{
${ }^{101}$ Radishchev, A Journey from St. Petersburg to Moscow. 143.

102 Roderick Page Thaler, "Introduction" in Radishchev, A Journey, 11.
} 
his sentence was soon commuted to banishment to Ilimsk, a small town in eastern Siberia, for ten years. In 1796, Paul I permitted Radishchev to return to one of his estates in European Russia, while keeping him under observation by the local authorities. ${ }^{103}$ After Alexander I came to the throne, hoping to but unsuccessful in urging the new emperor to adopt legal and constitutional reforms, and stung by the rebuke of his ideas by critics, Radishchev committed suicide by poison in September of 1802 at the age of $53 .{ }^{104}$

\section{A Journey from St. Petersburg to Moscow traced a fictional journey whose} narrator was based on Radishchev himself. This fictional journey was a compilation of stories, each titled after the name of a postal stop (resting station for Imperial couriers, change of horses, and travelers) The stories introduce readers to long-suffering peasants, evil and greedy gentry, pompous and venal officials and clergy. Throughout, Journey lamented the fate of the peasants, whose condition it equated to slavery, and whose ill treatment in turn, it argued, corrupted those among the free who might, without serfdom, have been good and noble people.

Landowners in Radishchev's work represented the worst that society could produce. Journey exposed their cruelty and rapaciousness. Near the postal stop of Lyubani the narrator encountered a serf who was forced to plough the fields of the landowner six days a week, meaning the labor due (barshchina) he owed to his landlord was an unusually high six day a week, leaving only Sunday for him to plow his own plot of land. The narrator surmised that the landlord must have refused to take a due in obrok

\footnotetext{
103 Thaler, "Introduction," in Radishchev, A Journey, 12-14.

104 Thaler, "Introduction," in Radishchev, A Journey, 17.
} 
(money or kind), thus forcing the peasant to stay on the estate and be barred from traveling to seek work away from his land. ${ }^{105}$ At Vyshny Volochok, the narrator heard of a landowner who compelled his villagers to work "everyday of the year for him." This estate owner filled his granaries and gained admiration as a "famous agriculturalist" by "multiplying the number of those groaning in his fields."

Turning to another facet in the oppression of serfs and the tyrannical arbitrariness of landlords, the narrator described a scene at Gorodnya that showed the destructiveness of military recruitment, as it tore young men from their families, dooming them to never return to their native village. But however distressful the life of a conscript, at Gorodnya the narrator found a young man who preferred it to suffering the constant torment his master's new wife directed at him with no fear of legal restraint. ${ }^{107}$ At Mednoe, the narrator came across an auction for selling a family of serfs. He decried the inhumanity and frequency of such auctions, which occurred "twice every week [and] the whole Russian Empire is notified" to attract prospective buyers, and the profligate landowners trying to pay their debts through these sales. At the Mednoe auction the narrator saw a family of serfs, an aged man who served loyally the father of the "young master" selling him; the serf's wife, an old woman who nursed the young master's mother; their daughter or daughter-in-law, a widow, who was the young master's wet nurse and "second mother"; and the granddaughter of the family, whom the lascivious master tricked and seduced, and who bore his child, an illegitimate son who was also to be sold with the

\footnotetext{
105 Radishchev, A Journey, 46-47.

106 Radishchev, A Journey, 158-159.

107 Radishchev, A Journey, 203-208.
} 
family. With sympathy Radishchev's narrator related the story of the young serf man on the auction block, the husband of the granddaughter. With "savagery ... in his eyes," the young serf, once "the companion and intimate of his master" whom the master used to deceive the girl who was then wedded to him, dreamed of vengeance. "A hopeless fancy!" the narrator interjected, for "government justice" would side with the landlord, and resistance would only lead to "a languishing death in fetters.",108

Sometimes even government officials could not endure the injustice of the laws. A traveler Radishchev's narrator meets on the road was a former judge on the provincial court who left his position because he could not uphold laws that served only to suppress and punish innocent victims while protecting the corrupted gentry. ${ }^{109}$ This and other stories led the narrator to reflect on the true nobility and dignity of the simple country people, who strove to make modest gains in the face of the increasing demands the gentry placed on them.

Radishchev's narrator described the lot of the serf as "of one cast into fetter, of one thrown into a dismal dungeon: the lot of the ox under yoke." He decries the condition of both the master and slave: "On one side there is almost unlimited power; on the other, helpless impotence. For the landlord is to the peasant at once legislator, judge, executor of his own judgements, and, if he so desires, a plaintiff against whom the defendant dare say nothing." ${ }^{110}$ Asking the question, "Can a country in which two-thirds

\footnotetext{
108 Radishchev, A Journey, 187-190.

${ }^{109}$ Radishchev, A Journey, 92-93.

110 Radishchev, A Journey, 221.
} 
of the citizens are deprived of their civil rights and to some extent are dead to the law be happy?"111 The narrator warned of the peasant insurrections that would result from the crushing oppression. Inveighing against this oppression, Radishchev's narrator appealed to his readers, "you [who] wish to be called merciful, and you [who] bear the name of the guardian of public good!" to take action. Against the "famous agriculturalist" who squeezed his serfs to fill the granaries, the narrator, akin to inciting revolution and rebellion, called on his readers to "destroy the tools of his agriculture, burn his barns, silos, and granaries, and scatter their ashes over the fields where he practiced his tortures; stigmatize him as a robber of the people so that everyone who sees him may not only despise him, but shun his approach to avoid infection from his example." 112 Throughout, A Journey from St. Petersburg to Moscow served as an impassioned argument for the state and the landowners to change their ways, and for serfdom's abolition, in effect.

Radishchev's Journey anticipated the central themes in the Consensus authors' studies of serfdom: the inhuman exploitation of serf labor, with landlords preferring barshchina to obrok, and pushing barshchina dues to the brink of the peasants' destruction; the equivalence of serfdom to chattel slavery, exemplified by the auction block; the arbitrary authority that landlords wielded over the enserfed, abetted by “government justice"; the landlords' cruelty, greed, and lasciviousness against which the peasants could hope for no defense from the state. While there were notable instances that matched Radishchev's exposé of landlord excess, it is not clear how representative

\footnotetext{
111 Radishchev, A Journey, 147.

112 Radishchev, A Journey, 159-160.
} 
they were, and the overall accurateness of the depiction of the landlord-peasant relationship Radishchev presented is questionable, as Chapter II shows.

Also, Radishchev neglected to take into account what Richard Pipes calls "the constraints of custom," which Pipes believes prevented the enserfed in Russia from "sink[ing] to the status" of the enslaved in North America, even though Pipes also agrees with the Consensus authors that by the eighteenth century, "landlords acquired virtually unlimited power over their serfs." From their perspective, when addressing their landlords about the land they lived on, the enserfed peasants persisted that, according to a well-known peasant saying David Moon quotes, "We are yours, but the land is ours," making it clear that although the landlords could attach them to the land, the land in turn was unbreakably attached to them. ${ }^{113}$ With regard to barshchina, a target of Radishchev's condemnation, how much labor a barshchina due could demand was often determined by custom, not by the landlord's greed. In some parts of the Russian Empire, such as "Little Russia" (today's Ukraine), the barshchina due was two days a week under Catherine II, very likely following customary practice. Paul I's 1797 law limiting barshchina to no more than three days a week, which "was presumably [issued] to protect the serfs against excessive exploitation," as Domar and Machina observe, in fact had the effect of raising the barshchina in these parts from two to three days a week. ${ }^{114}$

\section{Life of the Enserfed: Their Own Accounts}

\footnotetext{
${ }^{113}$ Richard Pipes, "Private Property Comes to Russia: The Reign of Catherine II," Harvard Ukrainian Studies 22 (1998): 435-437. Moon, "Reassessing Russian Serfdom," 502.

${ }^{114}$ Domar and Machina, "On the profitability of Russian Serfdom," Footnotes 10 and 23, pp. 923, 929.
} 
The serf- or former serf- authors this chapter discusses had experiences and occupation that, taken together, add up to a fairly different image of serfdom than that presented by Radishchev, even as some of these recollections expresses an aspiration for "freedom" that matched the message of Radishchev's stories in Journey.

The authors were literate at a time when literacy was not widespread even among serfs. Except for Vasilieva, who was a house servant (dvorovaia), these authors took up a wide range of occupations, even though the condition of serfdom was to be bound to land, they were highly mobile. The physical and social mobility of enserfed peasants was often evident in historical records and memoirist works, according to Boris B. Gorshkov, editor and translator of Saava Dmitrievich Purlevskii's autobiographical account. Serfdom, Gorshkov writes, while serving "its fundamental purpose of preserving hierarchy ... simultaneously opened the door to a certain societal mobility for serfs," as well as physical mobility, as testified by both active internal passport system and the growing seasonal migration of enserfed peasants in the first half of the nineteenth century, with regard to the quest for "freedom" invoked in some of these serf accounts, it is possible that it reflected not only the authors' sense of despair and anger in the face of the social hierarchy enforced by serfdom, but also, according to Gorshkov, "the language of freedom and equality" that the educated elites absorbed from reading the Enlightenment philosophers, and that "penetrated the minds and discourses of the common folk" as well. ${ }^{115}$

\footnotetext{
${ }^{115}$ Boris B. Gorshkov, “Introduction," in Purlevskii's A life Under Russian Serfdom, 6-7, 1, 19.
} 


\section{Nikolai Smirnov: A “Confession”(1785)}

The earliest of the autobiographical stories in this chapter, Nikolai Smirnov's testimonial was written in 1785. A contemporary of Radishchev, Smirnov was arrested that year for attempted flight across the Russian Empire's western border. Smirnov composed this account of his life in the form of a confession. Although spared the death penalty, which the court had considered a fitting punishment, he was sentenced to "have his nostrils ripped open," and faced being branded and beaten with a knout, as well as being sent to Riga (in today's Latvia) in shackles for hard labor. Collected in the files of the St. Petersburg Secret Investigation Office, this “confession” came out of Smirnov’s request to the general prosecutor to explain why he broke the law, and his show of "a desperate if ambivalent expression of penitence," according to MacKay. ${ }^{116}$

Smirnov was the son of a serf estate manager for the high-ranking old-noble family of the Golitsyns, who owned multiple estates near Moscow. Smirnov's father paid for his education, employing tutors to teach him Russian grammar as well as the basics of French and Italian. He went on to study at the Moscow University which was attended by many of Russia's elite, having been given special permission by the director that allowed him, a serf, to attend without formal enrollment. There he continued his education in such fields as history, geography, mythology, iconography, and English. He also engaged tutors to teach him mathematics, architecture, draftsmanship, and painting. But, "due to an illness I contracted" in Moscow, Smirnov returned home after less than a

\footnotetext{
${ }^{116}$ Mackay, "introduction of Nicolai Smirnov" Four serf Narratives, 23.
} 
year, where his father "kept [Smirnov] by his side" and put Smirnov to work on estate business. At home, while working for his father, continued his education with professors of Moscow University, who gave him private lessons in English, "a subject for which I had a great predilection.” Despite his illness and bad health, Smirnov continued his studies this way for over a year, until he was interrupted for just as long a period, having been called to work on the landlords plans for and estate villages" "wastelands and settlements," and, later, on compiling information for the government census. Carrying out these tasks, "every day I was compelled to write and copy orders and expense sheets for the village, to work on the account books, and to do many other things concerning the house and estate." This was work for which "I had not the slightest ability or inclination," Smirnov wrote. ${ }^{117}$

Smirnov wrote that he desired to "renew my now lapsed studies," and "these vexations and barriers continually placed in the way of my desires made my life ... utterly hateful to me." Frustrated at being forced to do clerical work on the estate, Smirnov saw himself as a "slave" (Kholop) "whose degrading name" incessantly reminded him that "I was in bondage on a heavy and oppressive chain." Smirnov pleaded with his father to petition the estate owner for manumission for his son to their masters. This request was denied, leaving Smirnov "without the slightest hope of ever enjoying that which seemed more precious than anything: freedom." 118

\footnotetext{
117 MacKay, Four Serf Narratives, 24-27.

118 MacKay, Four Serf Narratives, 27.
} 
Endeavoring to be manumitted by other means, Smirnov asked for help from his maternal uncle, a nobleman named Seniavin, a family connection that suggests Smirnov's mother might have belonged to a different estate status, possibly a member of the nobility. Seniavin was to negotiate with the Golitsyns to either replace Smirnov with two serfs of his own or to entreat the Golitsyns to send him off to the army. This request was also denied, once more leaving Smirnov in despair. Upon learning that his young masters, two Golitsyn lords, were going to voyage through Europe, Smirnov thought to sneak away to them and offer himself as a travel companion, thereby befriending them and earning their trust and eventual manumission from them, while gaining the chance to continue his studies of Italian language and architecture. With money stolen from his father, an extraordinary 3,500 rubles, false identity papers and travel documents, and the aid of a serf who studied architecture with him, Matvei Kurbatov, Smirnov and his "comrade Kurbatov" set out for Riga, intending to get across the border at the first opportunity. ${ }^{119}$

Midway in his journey to the border, Smirnov met swindlers who persuaded him to head instead For St. Petersburg, and led him "into sundry dissipations" and enormous expenditures. When arrested in St. Petersburg, Smirnov wrote, "I comforted myself with the thought that my adventures would conclude with my being delivered to my master," from whom "the only punishment I anticipated was conscription in the army," which fate Smirnov "had regarded as the greatest happiness."

${ }^{119}$ MacKay, Four Russian Serf Narratives, 28-29. 
Sentenced at first to execution by hanging, probably for not just for flight but also the impersonation of an Imperial officer, Smirnov was saved from death by the direct intervention of Catherine II, who commuted his sentence to exile, in the words of the Imperial order MacKay quotes, "as a soldier to the military troops stationed at Tobol'sk, a city in Siberia, where he remained for the rest of his short life." Catherine's intervention may have been due to the request of Princess Daria Alekseevna Golytsyna, to whom Smirnov wrote a letter, "tearfully asking her" for "intercession [to] preserve me from a most unspeakable death." In exile, Smirnov seemed to have continued to write, not confessions, but essays for publication, and very likely met Aleksandr Radishchev there, who was also living in exile in the city until his return to European Russia. Pavel Aleksandrovich Radishchev, in his biography of his father, mentioned "a certain Smirnov living in Tobol'sk" in 1797, when Radishchev was there. This Smirnov "was a freedman formerly belonging to Prince Golitsyn and had been educated with Golitsyn's sons. He knew French splendidly well, was involved in literary writing," and published articles under a pseudonym. ${ }^{120}$

\section{Peter O.: News About Russia}

Announcing himself as "the half-literate peasant, P." who "Belong[s] in body to a landlord,/But in soul, to Christ," the anonymous author of News About Russia declared his status as bonded yet "free" before God, asserting his own sense of what "freedom" meant. A poem of over 250 stanzas of varying lengths, News About Russia was given to

\footnotetext{
${ }^{120}$ MacKay, Four Russian Serf Narratives, 33-36.
} 
the post office in St. Petersburg in 1849, to be sent to Prince Petr Georgievich Ol' denburskii, kin of Nicholas I and reputed to be "liberal-thinking," according to MacKay. Finding it suspicious, the post office intercepted the package, and for the next year it ended up in the undelivered mail that was to be burned. Opened just before it was to be put in the flames, as required by the rules of the "dead letter" office, readers of the poem in the package deemed it "blameworthy" and turned it over to the notorious Third department, in charge of "political investigation and surveillance." The poem remained in the files of the department, not surfacing again until the soviet era. ${ }^{121}$

"The peasant P." intended for the poem to be read by Nicholas I, stating on the cover of the notebook in which he wrote that he wished to "dedicate my verse to the sovereign emperor Nikolai," with the condition that "he read everything contained in the manuscript," and he agree to "not prosecute the writer."122 The "news about Russia" that the peasant P. wanted to inform Nicholas of was, in effect, a petition appealing to the emperor to deliver enserfed peasants "from this bondage into a proper life." The author embedded in a sprawling account of life in his village and peasant commune deep grievances against landlords, his own and those that he heard of in his travels between his home village and "the city," Instead of a petition, the peasant P. had apparently taken the stratagem of dedicating a poem to the emperor because prohibitions against petitioning the sovereign were well known. In the poem, the father of the central narrator, Peter O., cautioned against attempting to speak to the sovereign: "Is it for the likes of you, my son,

\footnotetext{
${ }^{121}$ MacKay, Four Russian Serf Narratives, 38-40.

122 MacKay, Four Russian Serf Narratives, 40.
} 
to approach the tsar?/Is it for you to advise the great one/ ... In dull and colorless words?" The tsar would ignore the petitioner, or worse, his father warned: "he'll think to send you off/To a place where not even the ravens /Bother to carry off the bones." ${ }^{123}$

Peter O. began the poem by describing the thwarted and unhappy life of serfs. The father of the author was "a man of ambition" who "went off in search of arts and trades" when young. Disappointed in this endeavor, "he abandoned himself/To dissipation, drunkenness." His mother, after "earlier, happy years," which were passed in prosperity," now lived in poverty. At the age of fifteen, P. received permission to "live and work in the city," most likely St. Petersburg, where he found its "populous throng ... like a forest." Giving a clue to how city life might have changed him, the poet wrote: "there I came to know/Different people, another world,/And resolved to write these 'news."' 124

On his first journey back to the village after seven years in the city, Peter O. was "carried away by such a joy" at the thought of going home. Sailing on the Neva River, the river running through St. Petersburg, and its canals, he admired the beauty of the fields and meadows ashore, "natures kingdom" that "the almighty in heaven/watches over." But he lamented "the decrepit settlements" of the inhabitants, and "the ill-fated Muzhiks [male peasants]." This glaring difference led him to call his reader to "Observe the dominance of earthly powers/And the false splendor of their homes." Taking a break from his journey at a village stop to change horses, "the author P." met a horse keeper, an old man, who spoke of his fate as being "born into the world in chains." Impoverished by

\footnotetext{
${ }^{123}$ Peter O., "News About Russia," in Four Russian Serf Narratives, 62, 74-75.

${ }^{124}$ Peter O., "News About Russia," in Four Russian Serf Narratives, 41-42.
} 
taxes and the obrok he owed his landlord, the horseman declared, he was forced to "work and work." Throughout the poem the author condemned the burden of obrok, which he broadly defined as, in addition to the due in money and kind (quitrent), all of the fees, levies, and extortions collected by the landlords, for "the peasants call it all the same 'obrók.;" The poet found the labor due, barshchina (corvée), no better. According to Stepan, a character whose view the author purported to transmit "word for word," the landlords "wear the people down with bárshchina," and, leaving the peasants little time for their own plots of land, forced them to "plow in the rain," cut short their planting season, and lose part of their harvest. ${ }^{125}$

And yet the author took pride in the agricultural success of the empire. Along the Volga, "o holy river-" and the next big leg of his journey after the fluvial network of the river Neva, the author saw "caravans [of riverboats] filled with grain," a sight he wondered at and "could not look at ... /Without tears of joy," for "Russia had been so long under threat of famine. [Now] there's lots of grain in Russia." Grain, pronounced the author, was "better than gold." Welcomed by his waiting family and neighbors when he arrived home, the author heard of the neighbor's complaints of "the incomes taken from us by force!" and the "ruinous" payments the landlords extracted. At this, the author returned to his anger against the injustice of the "earthly powers." The author's father pointed to the pain and humiliation meted out to peasants by the gentry in his reproach/Against 'our' law," The father intoned: We see how the noblemen regard the peasant/As a fool, use 'peasant' as a term of abuse—-They use the same word to revile

125 Peter O., “News About Russia," in Four Russian Serf Narratives, 45-46, 83, 99. 
their enemies/Through us they are rich, at us they rage." More seditious than this reproach of injustices and mistreatment were the father' speech a few lines later, suggesting a demand for equality and rejection of social hierarchy: "But what do they have that we don't have?/ Look, and you'll see that in feeling and desire/They're exactly the same as we are." 126

The poem is replete with the author's appeals for freedom conveyed through various characters. Contrasting the justice of "the law of God" to the injustice of "our law," the father's oration continued: "And what must we put up with now?/God gave us minds and fields of earth/But there's no exit out of the fortress (sic, should be "contract" or "deed") doors/From this bondage to a proper life." ${ }^{127}$ Repeating a similar contrast, Peter O., riding on a cart on the last leg of his journey home, compared the beauty and splendor of the surrounding land to the privation of the region's inhabitants, "living together in a wasteland, in homes half-ruined." His driver, asked by the author how things could have gotten as bad as they were, replied, describing what was apparently the effect of seasonal and longer-term migrations: the locals had "scattered ... in all directions,/Leaving behind homes, wives, children,/They dwell in foreign lands, always

\footnotetext{
126 Peter O., "News About Russia," in Four Russian Serf Narratives, 51-52, 61, 83.

127 "Serfdom" (krepostnoe parvo), means literally "the right by formal contract or deed," with the word krepost' referring to a "formal deed," according to Elise Kimerling Wirtschafter. The more common meaning of the word krepost' is fortress, but that is not the right term for referring to serfdom. MacKay's conversion of krepost' to "fortress" may be a mistranslation, although it's possible peasants thought of the formal deed binding them to the land as a fortress. See MacKay, Four Russian Serf Narratives, 54, note no.23. And Wirtscafter, "Legal Identity and the Possession of Serfs in Imperial Russia," Journal of Modern History 70 (September 1998): 569.
} 
at work, never a bright day,/And tolerating much sadness." But the driver blamed this sad situation on the noble's greed for obrok, and by extension, serfdom, "the evil fate of horrible slavery." The author asked the driver what could be done for the people, and the driver replied "Freedom,/For tsar and Christian alike a single law!" ${ }^{128}$ That is, freedom, for Peter O., meant ending the contradiction between God's law and "our law."

\section{Aleksandr Nikitenko: A Freed Man's Story}

The account of his life by Aleksandr Nikitenko (1804-1877) is that of someone who obtained his manumission in 1824. It is the completed portion of and autobiography that Nikitenko began in 1851 but did not finish, given the title Up from Serfdom, the memoirs' translator Helen Saltz Jacobson undoubtedly suggests a Russian counterpart to Booker T. Washington's 1901Up From Slavery. Nikitenko attained a high degree of success in his life after his manumission, becoming a government official and a professor at St. Petersburg University, one of the two top universities in the Russian Empire, with the other being Moscow University. ${ }^{129}$ Nikitenko was born in the Voronezh Province in the village of Alekseyevka, in the southwest borderland of the Russian Empire. The Alekseyevka Sloboda (village) was an estate that belonged to the Sheremet'ev family, whose numerous estates had at that time altogether about 150,000 male serfs, according to Nikitenko. His father, Vasily Mikhailovich Nikitenko, was educated by the Sheremet'ev family, and began doing clerical work for the family at a young age and

\footnotetext{
128 Peter O., "News About Russia," in Four Russian Serf Narratives, 51-52, 62.

${ }^{129}$ Helen Saltz Jacobson, "Translator's Note," In Up from Serfdom, by Nikitenko, xxi. Peter Kolchin, "Forward," In Up from Serfdom, xix.
} 
became chief clerk of Alekseyevka Sloboda, his home village. Vasily Nikitenko and his family moved frequently, as Vasily's outstanding capability as estate manager was in demand and landed him jobs at various estates, and he takes many jobs during Nikitenko's childhood. Nikitenko started studying at his village school, and continued with his education at the country school in Voronezh. There he impressed his teachers with his ability and earned good marks. Unable to go on to attend high school due to his legal social status as a bonded person he returned to his family, now residing in Ostrogozhsk, a prosperous trading town in the Voronezh Province. There, at the age of fourteen, Nikitenko was given a position as a teacher at the country school in Ostrogozhsk, which he called "a comparatively good one" among many country schools. This was a highly unusual arrangement, which Nikitenko explained by the "strong spirit of opposition" that characterized "Ostrogozhsk society," leading it to "shun official teachers" certified by the government. ${ }^{130}$

Nikitenko met and developed close friendships with leading members of the educated in Ostrogozhsk, including military officers who were veterans of the Napoleonic War, among them General Dmitry Mikhailovich Yuzefovich. Not long after meeting him, General Yuzefovich offered the sixteen-year -old Nikitenko a position as the tutor of his two nieces, asking that Nikitenko move to Elets, to which the General was assigned. Elets was a commercial center and "one of the finest country towns" in the region, according to Nikitenko. In Elets, Nikitenko met and became good friends with members of the high-ranking nobility, who would later become his advocates in his bid

${ }^{130}$ Nikitenko, Up from Serfdom, 1, 6-8, 108, 115-116. 
for manumission. ${ }^{131}$ Nikitenko first confronted, at thirteen, the "terrible curse that hung over me because of my social status, which later ... almost drove me to suicide." When he graduated from the country school in Voronezh, he discovered that his legal status as a bonded person prevented him from being admitted to high school, the next level of education, even as a sympathetic teacher wished to help him by taking the dangerous risk of lying about his status registration in government documents. Nikitenko noted the precarity of the recognition he enjoyed in the elite social circles of Ostrogozhsk and Elets. In Elets, Nikitenko became "more and more aware of my status as a non-person" after General Yuzefovich, in an uncharacteristic outburst, snapped at Nikitenko for forgetting his social place, reminding him that he "possessed neither moral or [sic] corporeal rights," meaning legal social status, to such higher aspirations as literary ambition. ${ }^{132}$ Back in Ostrogozhsk after leaving General Yuzefovich, Nikitenko started his own school, which enjoyed great popularity in town. But here too he sensed the insecurity of his position. At a public event a "rival," according to Nikitenko, accused him of being a "tramp" and "self-anointed teacher" who "insolently intrude into the ranks of official teachers" open only to those in the unbonded social estates categories. This attack led Nikitenko to become "obsessed" with "my cruel fate" and "tormented by the thought that the law was still against me, and any day I could become a victim of unforeseen, hostile circumstances," he wrote. Admitting that "my craving for freedom and knowledge and for expanding the range of my activities possessed me to the point of

\footnotetext{
${ }^{131}$ Nikitenko, Up from Serfdom, 142, 150.

132 Nikitenko, Up from Serfdom, 92, 154.
} 
physical pain." Nikitenko, interestingly, invoked the empire's recent enemy, Napoleon, who stood as a symbol of social mobility for many in the lower social ranks. Had Napoleon, while still at military school, said "that he expected someday to be an emperor, he would have been sent straight off to an insane asylum," Nikitenko noted. Conceding that "I'm no Napoleon," and that "my claims are surely more modest. I'm not dreaming about a crown, but only a seat at the university," Nikitenko nevertheless made the comparison to Napoleon to draw out how difficult it was for him to acquire a higher social position, even though his exceptional talents should have easily qualified him for it. ${ }^{133}$

Resolved to obtain his freedom, Nikitenko wrote a letter to his landlord, Count Sheremet'ev, appealing for his manumission. The Count replied early in 1821, rejecting Nikitenko's appeal with the comment "Not worthy of attention". Nikitenko finally won his freedom in 1824, after gaining the support of Prince Golitsyn, the Prince, according to Nikitenko, "felt that my case was worthy of attention." Increasingly besieged by the social pressure exerted by Prince Golitsyn and other supporters of Nikitenko's cause in high society, as Nikitenko related it in the final chapter of his memoir, titled "My Struggle for Freedom," the count at last relented and released Nikitenko from bondage. ${ }^{134}$

\section{Nikolai Shipov: Liberation Through Captivity (ca. 1852)}

The memoir of Nikolai Shipov (1802-?), titled "the Story of My Life and Wanderings," was published in 1881 in the journal Russkaia Starina, (Russian of Yore)

\footnotetext{
133 Nikitenko, Up from Serfdom, 166-167, 169.

134 Nikitenko, Up from Serfdom, 182, 200-201.
} 
with a preamble by the author. The memoirs purported to cover the years from his birth to 1862 , although events recounted ended with 1852 . Shipov was manumitted in 1845 , in the midst of the Russian Empire's war in the Caucasus. Shipov obtained his manumission thanks to a legal statute that stipulated that, according to Shipov, enserfed peasants captured by the region's "mountain plunderers," that is, resisters and bandits who fought against Russian forces, were to be emancipated upon their escape from captivity. Daniel R. Brower and Susan Layton refer to Shipov's unusual path to freedom as "liberation through captivity," which, as they point out, was linked to Russia's conquest of the "imperial borderlands" of the Caucasus. ${ }^{135}$

Nikolai Shipov was born in 1802 in the village of Vyezdnaia in the Nizhnii Novgorod Province. His father was "a landlord's peasant," as Shipov described him, on an estate belonging to the Saltykov family, who were absentee landowners. Shipov's father was a successful cattle tradesman who "also dealt in tallows, fur, and skins." His father took Shipov on long journeys to purchase cattle in the steppe provinces of Simbirsk and Orenburg, whose local inhabitants included Muslims and Turkic peoples such as the Bashkirs, the Chuvash, and the Kazakhs. Beginning at age six Shipov was taught to read and write by the local priest, and later, after the cattle trade picked up again following the War of 1812, Shipov was taught the "secrets of his trade" by his father. According to Shipov, his father was "a literate and erudite man, honored and respected by

\footnotetext{
135 Nikolai Shipov, "The Story of My Life and Wanderings" in Four Russian Serf Narratives, 165-166. MacKay, Four Russian Narratives 196. Daniel R. Brower and Susan Layton, "Liberation through Captivity: Nikolai Shipov's Adventures in the Imperial Borderlands," Kritika: Explorations in Russian and Eurasian History 6, no. 2 (Spring 2005): 259-278.
} 
all," and "we the Shipovs were a wealthy family, one of the foremost in Vyezdnaia." No doubt because of his standing in the village, Shipov's father was "more than once" given the onerous job of estate bailiff, responsible for collecting taxes and obrok from the villagers. ${ }^{136}$

Adept at keeping accounts, Shipov included in his memoir frequent references to sums paid, received, or offered. Shipov related that for the years between 1820 and 1828 , the landlord decided that the entire estate of Vyezdnaia owed " 105,000 ruble assignat per year" in obrok. As one ruble assignat (paper ruble), according to Thomas Owen's calculation, was at that time roughly one-fourth of a silver ruble, this converts to about 26,250 silver rubles, still an enormous sum. During those years the obrok Shipov and his father were required to pay was five-thousand rubles per year (presumably also in assignat), on top of which they had to pay 800 rubles assignat per year for "the right to conduct trade." Another peasant in in Vyezdnaia "paid nearly 10,000" rubles (also assignat, presumably) per year in obrok, Shipov noted, as compared to the "110 rubles assignat per year" in obrok set in general for "each" 'census soul' (ravizskaia dusha)" in the village, that is, each male adult peasant registered since the latest census. ${ }^{137}$ For the Shipovs, the heavy burden of the obrok was not lightened by the landlord even in the

\footnotetext{
136 Shipov, "The Story of My Life," in Four Russian Serf Narratives, 120, 124, 127, 133. Brower and Layton, "Liberation," 265.

137 MacKay translates revizskaia dusha as "inventoried soul," which appears to be a mistranslation as it does not reflect that this term refers to the formal census registration of male peasants that was carried out periodically for the "soul tax." See Yanni Kotsonis, States of Obligation: Taxes and Citizenship in the Russian Empire and Early Soviet Republic (Toronto: University of Toronto Press), 43-44. Olga Crisp, "The State Peasants under Nicholas I," in Studies in the Russian Economy before 1914, ed. Olga Crisp (London: Palgrave Macmillan, 1976), 88-89.
} 
years when the family suffered "significant loses" from trade and faced the threat of "soon be[ing] completely ruined." The weight of the obrok, Shipov wrote, led "well off peasants [to attempt] to but their freedom," such as in the case of "one very rich peasant who $\ldots$ offered the landlord 160,000 rubles to manumit him and his family." In Shipov's own case, he and his father made a plea to the Saltykovs to free Shipov in exchange for 50,000 rubles assignat and a pledge that his father "would remain a serf," despite the increasing troubles directed at the father by the Saltykov's estate manager and a rival villager. The landlord denied these requests for manumission as a rule, Shipov wrote, while his own request was "categorically refused" by the estate manager even before it reached the landlord. It was at this point, in late 1830, according to his memoir, that Shipov started to look elsewhere for a way out of his condition: "I began considering running away," and "to try my luck in some alien land."138

In late 1831, told that he still owed an unpaid amount in obrok of 1,500 rubles assignat, Shipov left for St. Petersburg to plea with the Saltykov's estate manager for a reduction in this sum, "Nothing, of course," came of this, Shipov wrote, other than rumors that his property was to seized and he himself sent away to the army. These rumors deeply worried him, for "anything can happen to an enserfed slave—such were my thoughts at the time." In January 1832 Shipov fled his village with his wife to the borderland region of Bessarabia, by the Danube, to join his brother-in-law Stepan Lanin, himself a fugitive who left his home village five years before. Lanin, who worked in

\footnotetext{
138 Shipov "The Story of My Life," in Four Russian Serf Narratives, 125, 134-135, 138. Thomas C. Owen, "A Standard ruble of Account for Russian Business History, 1769-1914: A Note," Journal of Economic History 49, no. 3 (September 1989): 704.
} 
Bessarabia as a sutler provisioning the local Russian garrison, procured forged papers and false passports for the Shipovs. In the Molavian city of Batashany, near Bessarabia and inhabited by Moldovians, Jews, and persecuted Orthodox Christian sectarians such as the Old Believers and the Skoptsy, as well as Russian peasants, Shipov visited the bazaar and looked to reprise trading. ${ }^{139}$

“A year passed ... and I traded peacefully,” wrote Shipov. The Shipov’s growing family stayed in a city near Kishinev (in today's Moldova), and then in Piatagorsk, a city in the Caucasus, a region that, according to Brower and Layton, saw "a 'flood' of illegal ('passportless') migrants" since the start of the empire's Caucasus War. ${ }^{140}$ Shipov's pursuers were not far behind. The new bailiff at Vyezdnaia sent an agent to look for him, and offered 1000 rubles for his capture. Shipov was apprehended, returned to his home region, and incarcerated. Having avoided the harsher punishment of exile to Siberia, Shipov received, following a petition on his behalf, the lighter sentence that had him "reinstalled with my landlord."

By early 1842, Shipov was again allowed to travel. He left for Moscow, and then journeyed to the city of Kherson (in today's Ukraine, near Crimea), and the busy port city of Odessa, and to Kishinev. In Kherson, he met up with a cousin who obtained his freedom through the military. Of his cousin, Shipov wrote, "although he was a soldier, he breathed freely." He saw his own plight in stark contrast, for his was "a miserable

\footnotetext{
139 Shipov, "The Story of My Life," in Four Russian Serf Narratives, 142-144.

140 Shipov, "The Story of My Life," in Four Russian Serf Narratives, 145,151. Brower and Layton, "Liberation through Captivity," 267.
} 
existence, like a blade of grass all withered from lack of rain. And why? Simply because I wanted freedom above all else: because I sought ... my and my prosperity's independence from, that cruel-hearted landlord. ${ }^{141}$ In 1843, Shipov made a hugely important discovery as he was "pursuing [a] case" through the legal channels to recover his property from his uncle, with whom he had left it for safekeeping. Among the law books given him to read by a "civil servant," Shipov found, in what MacKay clarifies as the 1832 and 1842 Law Codes, statutes that pointed to a path to manumission unknown to him. According to Shipov, the statutes stated that "serfs who were captured by mountain plunderers would be free along with their family upon escaping from captivity. Those freed serfs would then have the opportunity, within nine months of escape, of selecting whatever life and type of work which best pleased them." At this point, in Shipov's telling, "I decided ... to attempt this severest of remedies, if only that I might be rid of the barin's [the landlord's] power over me." 142

Taking what little money he had, Shipov obtained a passport and travelled to the Caucasus region in early 1844, and again engaged in trading, this time by selling goods to the Russian regiment stationed at the fort of Vnezpanaia. He deliberately took risky night journeys, and, was caught by the so-called "mountain plunderers," a band of Chechens who was allied with Shamil, the best-known of the warriors fighting against Russian forces in the region. Shipov was held for ransom. Less than two weeks later, with the help of a Tartar who fell in with the Chechens, Shipov made a daring night escape back

\footnotetext{
${ }^{141}$ Shipov, "The Story of My Life," in Four Russian Serf Narratives, 164.

142 Shipov, "The Story of My Life," 165-166, MacKay, Four Russian Serf Narratives, 166; footnote no. 100.
} 
to the Russian fort of Vnezapanaia where he had been a sutler. One month later, while in Stravropol, a major Russian-controlled city in the Caucasus, "to find out the prices of cattle," Shipov submitted his petition for "my liberation from the landlord's proprietorship" to the magnate there, "along with the attestation of my captivity." Shipov's captivity by the Chechens attracted the attention of Count Mikhail Semenovich Voronstov himself, the Viceroy of the Caucasus and the commander of the Russian forces in the region. ${ }^{143}$ On a visit to Fort Vnezapanaia, the count, according to Shipov, “spoke very affectionately with me and asked about my time in captivity," and commended Shipov with the words “well done!” In October 1845, seven months after his petition, Shipov "receive[d] certification of my manumission" at the "Regional Government Office," and was at last released from his bondage. Trying to read the certificate aloud to his friends, Shipov wrote, "tears of joy confounded my vision, and I couldn't make out a thing." Shortly after his certification as a freed man, he travelled to Kherson to join his cousin, and to register as a member of the city's legal estate (soslovie) of the meshchane (lower-rank townspeople), an estate that included many merchants. In Kherson, Shipov was reunited with his family, all of whom now belonged to the meshchane estate. ${ }^{144}$

\section{Saava Dmitrievich Purlevskii: Commerce and Freedom (ca. 1868)}

\footnotetext{
${ }^{143}$ Moshe Gammer, "'The Conqueror of Napoleon' in the Caucasus," Central Asian Survey 12, no. 3 (1993): 253.

144 Shipov, "The Story of My Life," In MacKay, Four Russian Serf Narratives, 173, 185, 188, 191-192, 194195.
} 
The unfinished autobiography of Saava Dmitrievich Purlevskii (1800-1868) was first published in the Russkii vestnik (the Russian Messenger), whose editor N. Shcherban received the manuscript from an acquaintance who was "a great friend of the deceased author." 145 Purlevskii was born in the Yaroslavl province in a village named Velikoe, around 100 miles northeast of Moscow. According to Boris Gorshkov, translator of the memoir, this was a region where the majority of the inhabitants worked in kustar production, characterized by artisan crafts and cottage industry, and earned their livings as small tradesmen. Purlevskii stated that the estate that included his village originally belonged to the "sovereign court department," meaning that the inhabitants were state peasants then. But, he wrote, it was "probably" Catherine II who gifted the estate to a prince, who was benign and worked alongside his serfs to improve the estate's villages and surroundings. The prince, in need of money, according to Purlevskii, offered freedom to the peasants his entire estate, "2,500 souls" in all, for sixty thousand rubles, or twentyfour rubles per soul. But the estate's peasants could not come up with the sum. The estate was sold instead to a merchant, "not a nobleman," wrote Purlevskii. Gorshkov explains that the sale of the estate was likely in 1780. In 1790, as Purlevskii related it, the heir of the new owner imposed an obrok due that "seemed quite burdensome," putting "our elderly people almost in tears" as the recalled the prince's offer to set the entire estate "free forever." This story of the elder's regret and those of the village's increased obrok,

${ }^{145}$ N. Shcherban, "Preface," in Purlevskii, A Life under Russian Serfdom, 24. 
which Purlevskii heard in childhood, "reinforced my belief that peasant dependence was bitter!" the author asserted. ${ }^{146}$

In the next segment of the memoir, however, Purlevskii seemed to turn away from the idea that obtaining formal and legal "freedom" was necessary for peasants to avoid a life of "dependence." Listing the advantageous features that made commercial activities flourish in his village, he noted that it was centrally located, had "twice-weekly markets," a two-week fair around harvest time, and "the villagers' own sharpness." Describing the villagers of his grandfather's time, "as serfs belonging to the same person who paid a set rent and worked only rarely for the lord and who were therefore not overworked," Purlevskii contended that "our predecessors possessed full freedom to develop their own economic life."147

Purlevskii's grandfather, Petr Petrovich Purlevskii, traded in flax and yarn, which he sent to the northern port of Arkhangelsk, and in linen and canvas, which he directed to Moscow. His grandfather's "finances reached twenty thousand [rubles]," which was, Purlevskii observed, "a great sum in those times!" Petr Petrovich was elected estate bailiff, a position that in Purlevskii's telling reflected the respect and stature the grandfather commanded among the peasants. As bailiff, Purlevskii's grandfather put in "good order" the estate's affairs, "introduced bookkeeping," and started a credit pool for the estate's peasant commune that enabled them "to sell their goods at distant

\footnotetext{
${ }^{146}$ Boris Gorshkov, "Introduction," 11. Purlevskii, A Life under Russian Serfdom, 27, 29-30, 33-34.

147 Purlevskii, A Life Under Serfdom, 43.
} 
markets." ${ }^{148}$ Purlevskii's father, Dmitri Petrovich Purlevskii, as Purlevskii told it, was an “excellent" trader who had "his own money" and the confidence of the people he dealt with. "Our house was the finest in the village," Purlevskii recalled, and the family had two servants, one of whom "lived with us for about thirty years." His father, the author remembered, enjoyed "the best" relations with the landlord, to the point that the landlord “empowered my dad to administer the estate and represent him in courts and juridical institutions." But this responsibility often took Purlevskii's father away from his own business, as it frequently required him to travel. Purlevskii recollected that at age seven he began attempting to learn on his own the rudiments of reading and writing. Soon after his father sent him to the parish priest to study, and himself taught Saava "basic accounting and business." But, according to Purlevskii, his father "expressed sorrow" that Saava could not study "grammar, writing skills, and arithmetic," because at the time "serfs were not accepted into [city] schools," where those subjects were taught. ${ }^{149}$

Purlevskii was still a boy when his father passed away and his family's economic standing declined. The next year, 1812, was that of the Napoleonic War, as a result of which, as Purlevskii remembered it, "commerce had declined everywhere" while the costs of basic goods rose. "We managed to keep up," Purlevskii said of his family, and he himself took up trade, although this remains at a small scale until his marriage. He was married at eighteen to the only daughter of Petr Ivanovich, a "fellow-villager" who was "loved" by his employees and "respected" by the landlord, who entrusted to Petr

\footnotetext{
148 Purlevskii, A Life Under Serfdom, 43.

149 Purlevskii, A Life Under Serfdom, 43, 45-46, 51, 54, 57-59, 63.
} 
Ivanovich the job of transporting to St. Petersburg the iron produced at the landlord's Siberian Metallurgical mills. Subsequently, Purlevskii would be given a similar responsibility by a later landlord who inherited his village: to transport the mills' iron products to the great fair at the city of Nizhnii Novgorod. After his marriage, and aided by his father-in-law in his business, Purlevskii sensed "as if I had obtained some particular right," and "felt secure in having such a father-in-law on my side." His thought now turned to "achiev[ing] for myself, at any cost, the standing that my grandfather and father enjoyed." 150

Purlevskii related many stories of landlord's abuse of the power they wielded over their peasants. Some of these stories he heard and might have been part of local lore, while others he himself witnessed. Among the stories he heard might have been one reflecting the cruelty of a neighboring landlord, who set his hunting dogs on a serf boy for a minor offense. Apart from possibly hearsay tales, Purlevskii's own experience also provided many instances of landlord's inhumanity and excesses. In 1817, a year before Purlevskii's marriage, the estate's landlord demanded that all the estate's peasants pay their dues two years in advance, placing a huge financial burden on the village, and threatening to send those who failed to pay in full to the army. Sometime later the landlord commanded that "four tall men no older than twenty" and "four beautiful eighteen-year old girls" be sent to him in St. Petersburg, the men for serving as footmen,

${ }^{150}$ Purlevskii, A Life Under Serfdom, 64-65,71-74,109. 
and the women for purposes that Purlevskii did not bother to explain. Purlevskii, thanks to his family's connection to the bailiff, managed to avoid being selected.

In 1820, the estate's new owners announced to the estate peasants that they wished to both raise the dues and collect these dues ten years in advance, an exorbitant sum of "two hundred thousand rubles [to be paid] right now." As Purlevskii recounted it, the peasants refused the heirs' demand because they did not have this much money. The heirs then "mortgaged the entire estate of 1,300 serfs to the Council of Trustees for twenty-five years," passing it on to the government's guardianship for that duration in exchange for 325,000 rubles. The estate's peasants, in return, were to foot the cost of this mortgage plus interest in their rent, which came to thirty thousand rubles per year. Adding this amount to the taxes and fees they owed, the peasants' annual dues totaled fifty thousand rubles. This turn of events, and the "huge obligation" they resulted in, "shocked" Purlevskii and posed an "extraordinary concern to everybody," he wrote. Purlevskii explained, "this obligation seemed unlawful. But what could one do? In those days peasants were prohibited from complaining against their landlords." He continued, "willfully refusing to pay the lord would mean stamping ourselves with the stigma of rebellion," and lead to "harsh punishments, which would reduce everyone to complete impoverishment." Given this bind, Purlevskii saw that "the only consolation was our unrestrained freedom to engage in economic activities.” But it was also because of this 
shocking outcome of events, according to Purlevskii, "for the first time in my life, I tasted the sorrow of my status as a serf."151

The estate to which Purlevskii's village belonged to comprised in all of twentythree villages, in addition to a cotton factory, where the estate's peasants worked to pay their barshchina (labor due). Working conditions were poor, however. The factory's "German manager," hired by the landlord, "kept [the peasants] downtrodden in every way" and replied to peasants' complaints with flogging, wrote Purlevskii. That year, faced with peasants gathering to speak to him of their distress under his management, according to Purlevskii, the manager reported the gathering to the provincial governor as a mutiny, and brought the troops down on the estate's peasants. This attempt by the manager to charge the peasants with mutiny was dismissed by the provincial authority upon inquiry. But, expressing his view of the enserfed peasants' precarious and unpredictable life, Purlevskii commented: just as "everything seemed to have happened for the better, [it] then turned out for the worse." The manger again accused the peasants of rebellion, and this time, the provincial garrison occupied the estate's villages and rounded up a large group of peasants. "I myself was a witness of this," wrote Purlevskii. He described the heart-rending scene that followed: the younger ones, about a hundred in number, were "given a sound whipping," which they endured silently. "Those who were stronger tried to protect the weaker ones and stepped forward. Women cried sorrowfully, children screamed, I am barely able to retell what I saw ... the representative of the

${ }^{151}$ Purlevskii, A Life Under Serfdom, 75. 
authorities themselves turned away their faces and lowered their eyes." 152

Although Purlevskii deemed that the peasants" "guiltless suffering" in this instance was not in vain, as it caused the German manager to be replaced by "a Russian, a kind and indulgent man" who made numerous changes that benefitted and enriched the peasants, this episode "revived my old desire to free myself and my family from bondage." ${ }^{153}$ In his telling, Purlevskii first seriously considered purchasing his freedom after the 1820 incident when the sudden and steep increase of the estate peasants' obligations made him aware of "[the landlord's] power over us and the humiliating, slave like condition of all society," presumably because he saw "all society" through the lens of his own social position. Earlier, Purlevskii wrote, his "life objectives" pointed to attaining a prominence and prosperity comparable to his "fellow-villagers," now he was preoccupied by "thoughts about my serf status." By 1826, successful in trade, Purlevskii had enough money for "buy[ing] one's way out of serfdom." But he did not act on realizing "this cherished idea" at the time, since he found that being a serf did not hinder "the freedom of my commerce and my access to loans," and because he preferred, Purlevskii sort of admitted, not taking "the money necessary for buying my freedom" out of his business funds. The harsh punishment of the estate's peasants in 1828 pushed Purlevskii to make a bid for purchasing his freedom. But this bid was refused, according to Purlevskii, because the landlord decided the estate could not lose someone of

\footnotetext{
152 Purlevskii, A Life Under Serfdom, 96-101.

153 Purlevskii, A Life Under Russian Serfdom, 101.
} 
Purlevskii's abilities, and prohibited further talk of his redemption. Deeply disappointed, Purlevskii accepted this outcome with "a heavy heart."154

Having gained their trust, Purlevskii was given positions of great responsibility by his landlords (by then there was more than one), as the new estate bailiff, and as the supervisor entrusted with selling the iron produced at the landlord's Siberian mills at the annual fair in Nizhnii Novgorod, the largest fair in the empire and, in the second half of the nineteenth century, "the largest in Europe." ${ }^{155}$ As the estate bailiff, put in charge of estate business, and of the peasant commune that adjudicated the affairs of the peasants, Purlevskii, by his own account, acted to meet the commune's needs. He first put the peasants affairs in order, then, with funding provided by the landlords, and "without the slightest [financial] burden on the commune," built a communal school, as none had existed, and a "medical facility" with a salaried physician, who "taught several boys pharmaceutics and nursing arts." As the supervisor of the landlord's iron sale at Nizhnii Novgorod, Purlevskii acquitted his duties so well that he gained "the landlord's appreciation" along with a monetary reward. His "self-esteem" so boosted by this, wrote Purlevskii, "that I nearly gave up my idea of redeeming myself from serfdom."156

But, once again reminding Purlevskii of the precariousness of whatever success he achieved because of his serf status, he soon ran into trouble. "Everything was fine"

\footnotetext{
154 Purlevskii, A Life Under Russian Serfdom, 96-97, 101-102.

155 Catherine Evtukov, "Portrait of a Russian Province: Economy, Society, and Civilization in NineteenthCentury Nizhnii Novgorod (Pittsburg, PA: University of Pittsburg Press, 2011), 73. And Anne Lincoln Fitzpatrick, “The Great Fair: Nizhnii Novgorod, 1840-1890 (New York: St. Martin's Press, 1990).

156 Purlevskii, A Life Under Russian Serfdom, 103-107.
} 
until 1830, when a missed shipment of iron caused his landlords, influenced by Purlevskii's adversaries, the author suspected, to dispatch an inspector to check on his business conduct. By his own account, Purlevskii, believing "my case to be just," ignored his adversaries" "attempts at extortion" in exchange for directing the investigation in his favor, with the result that he was summoned to St. Petersburg, where one of the landlords was residing, "to explain things in person." Here the memoir ends abruptly, at the moment in 1831 just after Purlevskii entered the study of his landlord, a certain General A., with the words: "There, my future fate was settled, so I will relate our conversation in detail ...," which the author did not manage to do. ${ }^{157}$

What ensued in Purlevskii's life was supplied in 1887 by N. Shcherban, the editor of the journal that published Purlevskii's memoir based on what "people well acquainted with [Purlevskii]" told the editor. Shcherban suggested that Purlevskii's conversation with General A. did not go well, leaving Purlevskii with the thought that despite his innocence he was to face a humiliating penalty of corporal punishment, or exile to Siberia. "On th[e] very day" of that conversation, according to Shcherban, Purlevskii took flight, heading first to Moscow, then to Kiev, and finally to the Bessarabian region in the southwest, which also harbored Shipov and his wife some years later. Like the Shipovs, Purlevskii was also sheltered by the Skoptsy, Christian sectarians who believed in self-castration. Fearing forced conversion by his benefactors, according to Shcherban, Purlevskii fled the Skoptsy and took refuge with the Nekrasovtsy, a branch of the Old

157 Purlevskii, A Life Under Russian Serfdom, 109-110. 
Believers that settled in the Kuban region, by the Black Sea. In 1834, learning of the imperial decree that granted, in Shcherban's words, "all runaway serfs who committed no crimes \{the right] to settle freely in the Novorossiisk area" by the Black Sea. Purlevskii "immediately went to Odessa," the center of that region, and "obtained the status of townsman," meaning he was able to register in the estate category of meshchane, which effectively turned him into a free man. In Odessa, Shcherban informed the readers, Purlevskii resumed trading, this time in sugar, and prospered. Having done very well in his business and his "position ... solidified," Shcherban wrote, Purlevskii was able to move up another rung and register in the merchant (kupets) estate, a coveted status for traders. Shcherban traced Purlevskii moving to Moscow in 1852, and redeeming his son's freedom in 1856. Perhaps to emphasize the hardship Purlevskii endured fighting to obtain his liberation, Shcherban wrapped up the final period of Purlevskii's life with what the editor said was Purlevskii's reaction to the manifesto for the liberation of the serfs issued in 1861 by Alexander II, “the empire's reformer!”: Purlevskii, now “[an] old man ... without saying a word, dissolved into tears." 158

The memoir of M.E. Vasilieva came out in Russkaia Starina (Russia of Yore) in 1911, although, according to MacKay, whether it was penned before or after the 1861 Emancipation Edict is unknown. The memoir is unusual in that it was written by a serf woman, and told from a child's perspective Her story is also rare in that it illustrated the life of one of the dvorovye, or (household serfs), enserfed peasants who were put on domestic duties by landlords, and did household chores ranging from gardening, horse

${ }^{158}$ Shcherban, "Epilogue," in A Life Under Russian Serfdom, 111-114. 
grooming, driving carriages, and cooking, to serving as valets and keeping company with the landlords' children. Introducing the memoir, MacKay comments that unlike other serf narratives, Vasileva's did not include "comparisons between a previously enslaved and currently free condition," an omission that resulted, in his view, a "harsh reflection on the harshness of authority and submission," a harshness that was unsoftened by a portrayal of submission as a "performance for authority," which might have suggested the serfauthor's agency. Also absent in her narrative, as MacKay notes, were “'abolitionist' imperatives," since the Vasilieva did not show "the child-serf [to be] bent toward some future moment of liberation." In other words, as Gorshkov might put it, her narrative did not take up a "language of freedom" often present in other serf writings. ${ }^{159}$

Vasilieva, known by the diminutive of "Akul'ka" in the memoir, was born in an estate called Dubovoe, near Moscow, that belonged to the noble family she named "Bolotin," an alias. In a wording that suggests Vasilieva wrote this memoire after emancipation, she described her "former barin (lord)," or landlord, Petr Georgievich, "compassionate to his peasants." But his wife Varvara Ivanova, "a Circassian princess," according to Vasilieva, "was a beauty on the outside but had a cruel heart." Vaselieva explained that she was orphaned at the age of five and brought to "Granny Ustina," who was tasked with raising the estate's orphans. Vasilieva related that her early childhood was pleasant and she did not suffer from want. Describing this period, she wrote of herself and other orphans that "our lives were good." As Vasilieva told it, life at the

\footnotetext{
${ }^{159}$ Mackay, "Introduction: Serfs as Writers," 8, 11. M.E. Vasilieva, "Notes of a Serf Woman," in MacKay, Four Russian Serf Narratives, 197-198. and Gorshkov, "Introduction," A Life Under Russian Serfdom, 19.
} 
estate became more onerous for its peasants and herself when the landlord decided to return to Dubovoe with his family to reside there full time, instead of only paying periodic visits. ${ }^{160}$

Although she described the arrival of the family as having made the barin's resident village in the Dubovoe estate "more cheerful," Vasilieva emphasized the hardship the villagers had now to endure, not by referring to peasant obligations, but by turning to the character traits of the landlord's family for explaining its violent behavior toward peasants. Vasilieva's account of these character traits very much falls into line with the persona of the willful and unbridled pomeshchik and landlord depicted by Radishchev and by the Consensus Historians. Vasilieva presented the barin's elder daughter Praskov'ia Petrovna as kind, someone who "would intercede on behalf of the servant girls" even though she always received slaps from her mother for doing so. But the barin's son, a sixteen-year-old, and his second daughter, the youngest of the three children, were selfish and inhumane. "Nasty, capricious," the younger daughter, Son'ia Petrovna was "hated by all the domestics," as a word from her to her mother would lead to a beating by birch rod of the accused wrongdoer, According to Vasilieva, Son'ia's whims and demands, as Son'ia took a liking to the serf girl after chancing upon her, were what caused the author's childhood self, Akul'ka, to be brought into the barin's house to be raised as Son'ia's companion. The young lord Egor Petrovich was, as Vasilieva remembered him, "the very picture of a barin: tall, slender, with black arching eyebrows." He, the author recalled, was arrogant and sadistic, as he would walk past the

\footnotetext{
${ }^{160}$ Vasilieva, “Notes of A Serf Woman," in Four Russian Serf Narratives, 199-201.
} 
house serfs without noticing them, and liked to kill small animals, which he did with Akul'ka's cat in front of her. ${ }^{161}$

Devoid of the "language of freedom," Vasilieva's memoir emphasized instead the abuses of the landlords. Vasilieva's memoir comprised in effect a catalogue of cruel acts perpetrated by the landlord's family, although it is not entirely clear how many of these she herself experienced and witnessed, and how many were hearsay. Among the acts of violence she experienced were, aside from the killing of her cat by the young master, being punished in the young mistress's stead as her study companion. For example, when Son'ia failed to learn her lessons, Vasilieva wrote, the barin's wife would take hold of Akul'ka and "beat me until I bled." Another act of cruelty and disregard she witnessed occurred, according to Vasilieva, on the first day of her arrival at the barin's house to serve as Son'ia's playmate. She saw the barina (the lady) about to bathe. The barina appeared in full nudity before her menservants and refused to cover herself when asked by her husband to do so. To the barin's mild rebuke, "there are men here," Vasilieva wrote, the mistress remarked: "What men? ... Here are my serfs, ... They're no more to me than those two chairs over there."162

Of the stories that the girl Akul'ka heard, probably because they circulated in the estate, was one about the discovery of a body immured in the barin's house, suggesting that her landlord's father, said to be a favorite of Catherine II, murdered a serf, if not more than one. Another was that of the young barin setting the beard of the well-loved

\footnotetext{
161 Vasilieva, "Notes of A Serf Woman," in Four Russian Serf narratives, 203-205, 207.

162 Vasilieva, "Notes of A Serf Woman," in Four Russian Serf narratives, 210.
} 
estate steward (bailiff) on fire, to take revenge on the bailiff for stopping him from tormenting servant girls. The mistress apparently enjoyed causing pain, like her son. Of the barina's penchants, Vasieliva wrote that "she passionately loved beating children," and dealt with serf children who approached the manorial courtyard by "beat[ing] them until either they either turned blue from crying or fell silent and stupefied." Yet another instance of the mistress's inhumanity Vasilieva recounted was that of a young gardener, Seriozhka, who out of hunger took a "half-eaten bun" from the mistress's plate when she briefly left the dining room by the garden. Caught sight of by the mistress just as he was taking the bun, Seriozhka took flight, and leapt into a well to evade his pursuers. Vasilieva's memoir ended with this tale, stating that hearing of Seriozhka's death, "all the house serfs wept and said in a single voice: "A person has died for a few crumbs of bread!" 163

In Vasilieva's account, tales involving cruel and blood-thirsty masters were common, and good masters, like Akul'ka's landlord Petr Georgievich and his elder daughter Praskov'ia Petrovna, were both uncommon and ineffectual in preventing the bad ones from terrorizing peasants. The picture of serfdom Vasilieva offered was that of shocking violence. But between the lines, there seem to be views and impressions that remained unsaid by the author. For instance, recalling how she romped about the estate with the other orphans, she mentioned the children being allowed into the manorial house by the kindly bailiff. Inside the house, Vasilieva wrote, speaking for the child Akul'ka, "we thought we'd landed in heaven." At this point the adult author's voice came through

\footnotetext{
163 Vasilieva, “Notes of A Serf Woman,” in Four Russian Serf narratives, 198, 201, 204-205, $209-212$.
} 
as she described what gave the children this impression: the master's house, apart from being huge and bright, had "parquet floors, gilded furniture, and marble columns in the hallway."164 The girl Akul'ka had learned to read and write as well as dance alongside the young mistress, and these lines suggest that growing up, Vasilieva became accustomed to having in her surroundings costly materials, such that she was able to name them precisely.

More than the other serf authors reviewed in this chapter, Vasilieva might have tailored her reminiscences to readers' expectations in the post-emancipation era to see serfdom as simply an evil to be condemned rather than an institution to be investigated and analyzed. Unlike the other serf narratives discussed in this chapter, Vasilieva's focused showing of serfdom's evils, does not reveal very much about her thoughts and personality. And unlike these other narratives, it does not say much about how serfdom worked in the rapidly changing social, political, and economic world of Russia in the nineteenth century by showing how the enserfed might have adapted to this changing world.

\section{Freedom and Unfreedom}

The literary accounts in this chapter, both fictional and memoirist, all invoke the idea of freedom. The serf memoirs show that many among the enserfed, the authors themselves and the people they spoke of, were allowed both physical and social mobility, contrary to the image of serfdom presented by Radishchev and the Consensus Historians.

${ }^{164}$ Vasilieva, "Notes of A Serf Woman," in Four Russian Serf narratives, 201, 210. 
This brings up the question of what "freedom" meant for those who lived the life of bonded people, and those who contemplated this life as outsiders. This chapter shows that while some voices among the enserfed thought of "freedom" as the liberation of all peasants in bondage, such as Petr O., who asked "But what do they have that we don't have?" that justified the submission of one group of people to another, other voices, such as that of Smirnov and Nikitenko, spoke of freedom mainly as an individual quest impelled by their own exceptional talent. For Nikitenko in particular, what distressed him was not the oppression reflected in the extraction of labor obtained through obrok or barshchina, but the unpredictability, insecurity, and precarity of life that came with being a legal "non-person," as he put it. With regard to the extraction of labor in relation to serfdom, the personal accounts collected in this chapter raise the question of the boundary between freedom and unfreedom, as the authors, when they were serfs, were literate and sometimes highly educated, had access to a range of occupations outside agricultural work, and often traveled. The extent to which serfdom in Russia represented the unfree pole in the dichotomy of free and unfree labor, and the validity of this dichotomy itself, as insisted on by the Consensus scholars, but questioned by the Revisionist historians, will be examined in the next chapter, which places Russian serfdom in the global context. 


\section{CHAPTER IV}

\section{LABOR EXTRACTION IN THE GLOBAL CONTEXT}

This chapter will examine serfdom in the Russian Empire in connection to a range of methods or systems in other parts of the world that were set up for procuring labor, both "free" and "unfree." The chapter will focus in particular on the so-called "long nineteenth century," which began in the late eighteenth and ended in the early twentieth. ${ }^{165}$ The long nineteenth century saw the expansion of the world market and the deepening of global economic ties, along with a phenomenal growth in the global demand for consumer goods and industrial raw material. While this was an era that ushered in political movements that, appealing for mass support and mass participation, promoted ideas and ideologies invoking "freedom," it was also a period that saw the emergence of new ways to capture and extract labor, whether it was called "free" or and "unfree," in response to the immense new labor needs created by the acceleration of industrialization and the ballooning demand for new commodities. This chapter begins with an examination of the terms "second serfdom" and "second slavery," as these terms point to labor formations that are often seen as the prototypes of unfree labor in the modern era.

\section{"Second Serfdom" and "Second Slavery": Common Views of Unfree Labor}

\footnotetext{
${ }^{165}$ For the historical changes associated with the notion of the "long nineteenth century," see C.A. Bayly, The Birth of the Modern World, 1780-1914 (Oxford, and Malden, MA: Blackwell, 2004), and Jan Nederveen Pieterse, "The Long Nineteenth Century Is Too Short," Victorian Studies 48, no. 1 (Autumn 2005): 113-123.
} 
The term "second serfdom" has commonly been used by scholars taking a Western Europe-centered view of historical evolution to refer to the enserfment of peasants in certain regions, such as Eastern Europe and Russia, that occurred centuries after serfdom had ceased to exist in another region, namely Western Europe. While a review of the formations of bonded labor across the world may prove this timeline to be overly reductive, rather than filling in on this timeline, this chapter will focus on the arguments presented by scholars who refer to this term, and another related to it, "second slavery," in order to contrast these arguments with those that question the interpretations of labor formations these terms suggest.

The notion of "the second serfdom" usually refers, according to Alessandro Stanziani, to "the recrudescence of corvée [labor obligation] in Eastern Europe and Russia from the seventeenth through the nineteenth centuries." 166 The comparative study of serfdom by Jerome Blum, the Consensus Historian discussed in Chapter I, even though it does use the term "second serfdom," is devoted to explaining the central problem defining this term: serfdom's "recrudescence" in the eastern part of Europe, after having disappeared from Europe's western part. Starting first with the situation in Western Europe, by which he largely means England, France, the western German states, and Flanders, writes that in the twelfth century the majority of peasants there were serfs, but that a century later, many serfs had become free. In England for example, he states, between one third to one half of its peasants were free by the turn of the thirteenth

\footnotetext{
${ }^{166}$ Stanziani, Bondage: Labor and Rights in Eurasia from the Sixteenth to the Early Twentieth Centuries (New York: Oxford; Berghahn Books, 2014), 2.
} 
century, and in France at that time serfs comprised a minority among peasants. By the late sixteenth century, Blum notes, "all, or nearly all, of the peasants ... were entirely free" in many parts of Western Europe, and those who were not completely free saw their bondage to the seigneurs significantly weakened. Blum attributes the reasons for this shift toward greater freedom to the economic expansion in Western Europe during the twelfth and thirteenth centuries, which was reflected in the increase in population, growth of cities, the increased expansion of arable land, the growing use of money, as well as the rise of the prices of agricultural goods. These changes, according to Blum, spurred landlords to both convert labor dues to money dues and to increasingly make concessions to peasants, effectively turning their serfs into "free tenants" who were "paying a money rent" as early as the end of the thirteenth century. But if economic expansion contributed to this movement toward greater freedom, so too, in Blum's view, did the severe economic contraction of the fourteenth and fifteenth centuries that hit most of Western Europe. This was because the downturn, according to Blum, not only significantly brought down grain and land prices, and led to a sharp decrease in tilled land and to abandoned rural holdings, but also resulted in a drop in population, and thus a serious labor shortage. Blum contends that the labor shortage forced up wages while inducing landlords to offer more concessions to peasants, such that "remarkably enough, the process of emancipation ... was continued" from the time of economic expansion into "these hard times."167

\footnotetext{
167 Jerome Blum, "The Rise of Serfdom in Eastern Europe," American Historical Review 62, no. 4 (July 1957): 810-811.
} 
Turning eastward to beyond the River Elbe, which for Blum marks the dividing line between Eastern and Western Europe, his study shows a dramatically different picture, In Eastern Europe, which the authors understands as roughly comprising of Prussia, Bohemia (today’s Czech Republic), Poland, Livonia (today’s Estonia and Latvia), and Russia, the non-noble population was made up of both "free cultivators," or "free men," and "the unfree," with the "free" population of peasants being entitled to certain rights, such as the "hereditary right to their holdings." However, Blum argues, unlike what occurred in Western Europe, a contrary trend emerged in Eastern Europe, one that led "toward the loss of [peasants'] old freedoms," such that by the late fifteenth century "from the Elbe to the Volga, most of the peasantry were well on their way to becoming serfs.” For Blum, the key moment separating Eastern from Western Europe was the economic depression of the fourteenth and fifteenth centuries which struck both parts of Europe, and it was in their response to the depression that "East and West followed diverging roads, one leading to more serfdom and the other to freedom." In Blum's view, whereas landlords in Western Europe dealt with the slump by offering higher wages and concessions to peasants, to alleviate the resulting labor scarcity, the nobility and gentry east of the Elbe, faced with the "depopulated villages and empty homesteads" and the ensuing labor shortage, reacted by imposing heavier duties on peasants and restricting their movement. ${ }^{168}$

Blum attributes this divergence between East and West to several factors: that the landed nobility and gentry, in Prussia and Poland for instance, were becoming more

\footnotetext{
168 Blum, “The Rise of Serfdom,” 813, 819-821.
} 
politically powerful relative to the sovereign and to other corporate groups; that more landlords in this period, in Prussia for example, were "becoming producers for the market," and therefore preferred labor dues and tying peasants to land, over money dues and permitting peasant mobility; and that the East, unlike the West, saw "the decline of the cities and of the urban middle class," by which Blum presumably means the absence of a bourgeoisie that could challenge the nobility. ${ }^{169}$ As this pattern does not fit the situation of Muscovy, since the boyars were weakened in this era, Blum provides a modified set of reasons to shoehorn in the Muscovite case. "In Russia," he writes, "a strong central power emerged" from the turbulence of the fourteenth and fifteenth centuries "in the persons of the princes of Moscow." The princes, to defeat the great nobility, relied on and raised the lesser nobility to political prominence. ${ }^{170}$ By pointing to the rise of the lesser nobility instead of "the urban middle class" in the wake of the upper nobility's defeat, as was the case in Western Europe, Blum is thus able to cover the Russian case with his general framework for Eastern Europe, for in Russia too, it was the nobility's hold on political power, and the successful pursuit by the lesser nobility, the pomeshchiki, of its interest, that led to the gradual enserfment of peasants, as Chapter I shows.

Summing up his explanation for the different developments in approaches in the "East and West" in regards to peasant freedom, Blum stresses two critical points.. One is, as mentioned above, the political rise of the noble estate, which gained increasing power

\footnotetext{
169 Blum, "The Rise of Serfdom," 822.

170 Blum, "The Rise of Serfdom," 823.
} 
over the peasants, being consented to by the central authorities, gave even more jurisdiction over the peasants. As a result, Blum writes, "Eastern nobility, in pursuit of what it conceived to be its own interests, was able to establish economic and social control over the peasantry and to dominate over the townsmen," since in these parts of Europe the nobility was not only empowered to control peasants, but also acquired the commercial rights usually held by merchants and traders. Intertwined with this point is another, what Blum observes as the overall decline of in cities and the nobility's domination over townspeople, the precursor of the "urban middle-class." As a result, according to Blum, in Eastern Europe, including Russia, "an important bourgeoisie class failed to develop." ${ }^{\prime 11}$ In short, Blum, echoing many Cold-War era Western scholars who consider the rise of the bourgeoisie as indispensable to the development of political freedoms, explains Eastern Europe's "second serfdom," and its failure to embark on the road to freedom, by the absence of a bourgeoisie and the prevailing of the nobility over other social estates. Implicit in Blum's explanation for the emergence second serfdom in Eastern Europe is the region's backwardness in historical development in contrast to Western Europe, seen specifically in the economic and political failures of "the East" brought on by a missing middle class and by the consolidation of power by the nobility and the central state. In this view of second serfdom, the use of forced labor is associated with a failure to become part of the "modern" world spearheaded by developments in Western Europe.

${ }^{171}$ Blum, "The Rise of Serfdom," 835-836. 
The term "second slavery" as Dale Tomich and Michael Zeuske note, "suggests an analogy with the 'second serfdom." But, in fact, while both terms point to a common historical development, the increased use of coerced labor in the modern era, this analogy breaks down in the way scholars who refer to these terms envision what is "modern." Tomich and Zeuske define "second slavery" as the "systematic redeployment and expansion of Atlantic slavery during the nineteenth century,." and opposes it to "the more common view that chattel slavery was ... an archaic institution that was incompatible with modernity, that was condemned to extinction after the advent of industrial capitalism, modern political regimes, and liberal ideologies." For Tomich and Zeuske, the very concept of the "second slavery" itself brings attention to the substantial economic expansion in the Atlantic world between 1780s and 1840s, which "resulted in the decline of old zones of colonial slavery and the formation of highly productive new zones of slave commodity production." 172 In other words, whereas critics of "second serfdom" like Blum see "unfree" labor as incompatible with modernity, researchers of "second slavery" such as Tomich and Zeuske find the coercion of labor to be part and parcel of the modern world, as it underpinned the modes of economic expansion that defined modernity.

Peter Kolchin, like Blum, asserts a clear distinction between free and unfree labor. In his comparative study of slavery in the American colonies and serfdom in Russia, Kolchin places both squarely in the category of unfree labor, as in his view "both were preeminently systems of forced labor." Even though he does not use the terms "second

\footnotetext{
${ }^{172}$ Dale Tomich and Michael Zeuske, "Introduction, The Second Slavery: Mass Slavery, World Economy, and Comparative Microhistories," Review (Fernand Braudel Center) 31, no. 2 (2008): 91.
} 
serfdom" and "second slavery," Kolchin considers these two forms of labor extraction to be similar, or "analogous," as Tomich and Zeuske might word it, in that both were connected to economic changes beyond the local level. Kolchin further asserts, like Blum, a distinction between slave labor in the New World and the steady loss of rights among the peasantry in Eastern European lands in conjunction with the growing power the planter and landowning classes in the Atlantic World and Eastern Europe, both of which he broadens into a difference between Europe proper, consisting of "the more economically advanced nations of western Europe," and its periphery, comprising of the colonies of the European empires and "the eastern European countries from the Baltic to the Ukraine." Kolchin sees a "remarkable growth in the use of unfree labor" at "Europe's borders" in response to the labor shortage that followed the European geographical and economic expansion in the sixteenth and seventeenth centuries. In his view, this growing reliance on unfree labor "stood in marked contrast to its continuing decline in ... western Europe." ${ }^{" 173}$

Kolchin's comparative study covers from the origins of both institutions of labor and how they hardened into "preeminent" forms of forced labor by the nineteenth century. Looking at the European colonies in North America, Kolchin writes that at the beginning of the colonies' expansion, Europeans were easy to attract to meet the colonies' labor shortage because of the favorable wages offered. But this source of labor

\footnotetext{
${ }^{173}$ Kolchin, Unfree Labor: American Slavery and Russian Serfdom (Cambridge, MA: Harvard University Press, 1987), 1-2, 385. (footnote 1) In separating Europe's center from its borders, Kolchin follows Immanuel Wallerstein's idea of a European "core" divided from its "periphery" both to the west (the colonies) and to the east (Eastern Europe). See Wallerstein, The Modern World System, Capitalist Agriculture and the Origins of European World Economy in the Sixteenth Century (New York, Academic Press, 1974).
} 
was neither permanent nor hereditary, and it was at times difficult to control, especially in the case of runaways. The colonists started transporting Africans to North America "as early as 1619," at first at a trickle. But by the period between 1680 and 1730, the use of "the forced labor of blacks" to supplement "that of whites [European indentured servants] in Virginia," for instance, took increasing hold, such that, according to Kolchin, "slaves became the backbone of the labor force in the [colonial American] South." In this period, the colonies' planters grew more prosperous exporting various cash crops, such as grain, rice, and tobacco across the ocean to the European market. Their rising wealth, as Kolchin notes, allowed them to purchase more enslaved Africans, and thereby entrench the use of slave labor in agricultural production for export. ${ }^{174}$

Drawing an analogy between the North American colonies and the Muscovite territories, Kolchin states that in Muscovy there was also "considerable production for market among seventeenth-century landholders," observing that "any surplus [over what peasants consumed] was available for sale." He points to the capacity to produce for the market of serfs in both private and monastic estates across "different districts of Russia" by noting that it was they who brought "a wide variety of food items - butter, eggs, chickens, geese, sheep, fish, and the like - to the nobleman's table in Moscow." Although producing a surplus that could be sold on the local and regional market does not quite equate with producing cash crops for the world market, and although, as Kolchin admits in an endnote, "Russian exports in the sixteenth and seventeenth centuries" were "minor," Kolchin's insistence that both peripheries faced comparable pressures allows him to

${ }^{174}$ Kolchin, Unfree Labor, 12, 14, 19-20. 
argue for the similarity of each periphery's response to these pressures, slavery serfdom. $^{175}$

The first conclusion Kolchin draws from his comparative study is the equivalence of North American slavery and Russian serfdom. Kolchin writes that "Russian serfdom was a very particular type of slavery, with features that in many ways resembled those of America's 'peculiar institution' [of slavery]," even though he acknowledges that "Russian serfs were able to lead lives that ... were much more independent than those of American slaves." Citing Consensus scholars such as Blum as his source, Kolchin asserts that the eighteenth-century pomeshchik had as much power "over his serfs ... as that of the American slave owner over his chattel—almost total, short of deliberate murder." So great was this power, according to Kolchin, again citing scholars like Blum, that "serfs could be bought and sold, traded, won and lost at cards. They were, in short, personal property." Kolchin offers that his view concurs with that of Lenin, who saw no difference between a serf and a slave; that of Blum, who finds the eighteenth-century Russian serf to be "scarcely distinguishable from a chattel slave; and that of Alexander Gerschenkron, who declares that in Russia "serfdom had ... degenerated into outright slavery."176

The second and less explicit conclusion that Kolchin makes is that the use of unfree labor lies outside of the core of Europe and was not inherent to the modern era, as unfree labor became common only at the borders of the European "core," and at a time before there was "a system of values" that found coerced labor objectionable. That is,

\footnotetext{
175 Kolchin, Unfree Labor, 22-23, 393 (endnote 38).

176 Kolchin, Unfree Labor, 41-43, 46.
} 
Kolchin suggests that acceptance of unfree labor was part of a premodern viewpoint, for "until the middle of the eighteenth century ... slavery and serfdom created few moral problems for anyone." ${ }^{177}$ In taking this stance regarding the relationship between coerced labor, modernity, and core European values and practices, Kolchin largely agrees with Blum. This chapter's next section will turn to scholars who challenge these views.

\section{Unfree Labor: Revisionist Views}

Writing on serfdom in Russia in the broader context of labor bondage in Eurasia, Alessandro Stanziani identifies "conventional approaches" to comparing slavery and serfdom as those that are informed by "ideal types [meaning theoretical definitions] rather than historical realities." By referring to "an ideal definition of each term" that are deemed to include such shared features as "the lack of legal rights allotted to slave and serfs, their hereditary statute, the master's right of ownership, and the coercive extraction of surplus," Stanziani states, these approaches end up confirming that slavery and serfdom are almost the same. ${ }^{178}$ Historical realities, however, as Stanziani argues and as explored in Chapter II and Chapter III, show serfdom in Russia to be in practice more flexible, and more likely to allow for the enserfed to obtain a different legal status, than what serfdom's formal restrictions might suggest. The flexibility of serfdom in practice, and its evolution toward including more flexible obligations over time, is one of the key findings of Revisionist Historians such as Stanziani.

\footnotetext{
177 Kolchin, Unfree Labor, 31.

178 Stanziani, Bondage: Labor and Rights, 8-9.
} 
But even with regard to formal legal definitions and restriction, Russian serfdom differed from slavery in the Americas in substantial ways. One critical distinction, which Kolchin mentions but does not judge important, is that, as Stanziani writes in his review of Kolchin, "unlike slaves, serfs were attached to the land," and not legally considered to be the personal property of the landlords. Another major distinction, Stanziani notes, citing the influential historian Michael Confino, is the autonomy of peasant communes and the function of the commune as an entity of peasant self-government. These distinctions, as Stanziani observes in his sum-up of Confino, are among the reasons why "the master-slave relationship did not find an equivalent in Russia, where the peasant commune and its elders mediated the relationship between the estate owners and the peasants." Relaying Confino, Stanziani writes, "the Russian master was therefore much more obliged to negotiate peasants' services than was the American slave owner." Going beyond Confino, Stanziani further argues for other significant divergences between slavery and serfdom, pointing to the relationship between enserfed peasants and the state, to the extent of economic autonomy peasants had, and to the peasants' participation in the empire’s territorial expansion. “Unlike American slaves," Stanziani writes, "Russian peasants constantly brought judicial litigation" against their landlords, "developed their own economic activity," which they pursued by "pay[ing] fees to their masters," and helped consolidate Russian territorial gains in the steppe and in Siberia by settling in these regions beginning in the seventeenth century. Challenging Kolchin, Stanziani 
concludes, "it makes no sense to consider American slavery and Russian serfdom to be similar institutions." 179

To say that serfdom in Russia and slavery in North America were not alike not only undermines the assertion of scholars like Kolchin, who see both as "preeminently systems of forced labor," but also raises the question of where exactly the boundary between "free" and "unfree" labor is to be located. Active since the post-Cold War era, more recent scholars, unlike Blum and Kolchin, query the division between the West and the East (or the non-West), and that between modernity and the premodern age, divisions that Blum and Kolchin mapped on to the geography of where "free" and "unfree" labor can be found. These scholars of more recent comparative studies, including Stanziani, show that there was no clear-cut line between free and unfree labor in the period of global economic expansion during the long nineteenth century. They find that alongside serfdom in Russia and slavery in the Americas, other significant forms of coerced labor existed. They also find that labor bondage continued to exist after formal emancipation, providing an important source of labor feeding economic demand across the world.

What was remarkable about the nineteenth century, usually seen as that of the peaking of the modern era, was that slavery in the Americas was entrenched, and new forms of coerced labor were devised both as supplement to and, after its abolition, as replacement for slavery . Serfdom in Russia, by contrast, as Chapter II shows, was slowly shifting toward more flexible arrangements and permitting an increasing number of

\footnotetext{
179 Stanziani, Bondage: Labor and Rights, 8-9. Michael Confino, "Servage russe, esclavage américain," Annales ESC 45, no. 5 (September-October 1990): 1119-1141.
} 
enserfed peasants to be manumitted. Regarding slavery, as Dale Tomich mentions, there is a common and persistent "presumption that slavery is incompatible with the modern world." He argues against this presumption, and against "a type of domino theory" that, viewing "Britain as the harbinger of a modern political, economic, and ideological order," insists that "once Great Britain abolished the slave trade [in 1807], the fate of African slavery in the Americas was sealed." Tomich shows that interpretations of slavery, or unfree labor, as giving way to free labor as the nineteenth century unfolded are erroneous, for it was during this "anti-slavery century" that slavery reached "the apogee of its development." 180

Enrico Dal Lago, looking to the nineteenth-century Atlantic plantation systems in the U.S. South, Brazil, and Cuba, and to the landed estate systems in Russia, Spain, and southern Italy, concurs with scholars such as Tomich and Zeuske that slavery and the modern era proved to be fully compatible, as reflected in the increased use of slave labor to meet the expanding cash crop production for export. Dal Lago notes in addition that in addressing the labor shortage due to the growth of world commodity markets, landowning agricultural producers relied not just on slave labor, but also on other forms of coerced labor, such as that of tenant farmers, sharecroppers, and indentured workers. According to Dal Lago, the technological innovations of the nineteenth century that constituted the hallmark of modernity also profoundly reshaped both the supply of agricultural exports and global demand, by making possible the mass production of

\footnotetext{
180 Dale Tomich, "The 'Second Slavery': Bonded Labor and the Transformation of the Nineteenth-Century World Economy," in Critical Readings on Global Slavery, ed. Damian Alan Pargas and Felicia Rosu (Leiden, The Netherlands: Brill, 2017), 1326-1327.
} 
exports for distant markets. For instance, the broad use of cotton gin in the U.S. by the 1790s, and the widespread adoption of the steam-powered mills on sugar plantations in Louisiana from the 1820s onward, Dal Lago writes, "heralded the massive expansion of the 'Cotton Kingdom' in the ... Old Southwest," and "increased enormously the production of sugar" by Louisiana's planters. Together with mechanization, many slaveholders also adopted new techniques of factory management "to enforce the regimentation of labor" of their enslaved workforce, according to Dal Lago. Finally, the arrival of railroads and steamboats, nineteenth-century emblems of progress, along with the extensive infrastructural construction reaching into continental interiors and connecting land and sea routes, allowed planters to vastly increase the surface area of cultivation and rapidly transport remote plantations' output to metropolitan centers. Thanks to these changes, Dal Lago points out, such cash-crop producers as the Brazilian coffee plantations and Cuban ingenios (sugar mills), became the world's leading suppliers of coffee and sugar as early as the 1830 s and the 1840 s, respectively. ${ }^{181}$ The success of these producers in turn led to further production expansion, new demands for labor, and efforts to intensify labor extraction.

In the U.S. antebellum South, in the cotton fields as well as the sugar- growing areas in Louisiana, for instance, “the exhausting 'gang-system', as opposed to the more humane 'task-system,"” was adopted to maximize productivity and "improve rationalization of labor management," Dal Lago writes. In nineteenth- century Brazil,

\footnotetext{
${ }^{181}$ Enrico Dal Lago, "Second Slavery, Second Serfdom, and Beyond: The Atlantic Plantation System and the Eastern and Southern European Landed Estate System in Comparative Perspective, 1800-60," Review (Fernanda Braudel Center) 32, no. 4 (2009): 412-414.
} 
coffee planters implemented a mixture of the "gang system" and the "task system," that, according to Rafael de Bivar Marquese, imposed "an incredible amount of work on slaves." Interestingly, added to this mixed system of labor intensification was the Brazilian planters' attempt to use not only force and coercion, incentives to heighten productivity. The planters, according to Dal Lago, "paid in monetary terms those slaves who worked beyond their minimum required tasks." ${ }^{\prime 182}$ In the Cuban sugar plantations, by 1847, four decades before the abolition of slavery in Cuba, there too was a mixed system of labor, in this case a mixture of slaves and workers "hired ... as indentured servants," Dal Lago shows. On these plantations, the "hired" workers, who were "Chinese coolie laborers" recruited from coastal China, often by deceit, worked alongside the enslaved of African descent; both groups "worked in gangs (cuadrillas)," supervised by overseers and drivers who used meted out severe punishments to force the work-gangs to keep pace with what Robert Paquette calls the "factory-like rhythms" of the plantations' mechanized sugar mills. ${ }^{183}$

The use of indentured labor was a common method taken up by planters and colonial authorities for filling the labor needs of new territories. According to Richard Allen, "the migration of 400,000 to 460,000 or more mostly British indentured 'servants' to North America and the Caribbean between the 1640s and 1775 established the

\footnotetext{
182 Dal Lago, "Second Slavery," 406-407. Rafael de Bivar Marquese, "African Diaspora, Slavery, and the Paraiba Valley Coffee Plantation Landscape: Nineteenth-Century Brazil," Review (Ferdinand Braudel Center) 31, no. 2 (2008): 202.

183 Dal Lago, "Second Slavery," 407. Lisa Yun and Ricardo Rene Laremont, "Chinese Coolies and African Slaves in Cuba, 1847-74," Journal Asian American Studies 4, no. 2. (June 2002): 99-122. Robert L. Paquette, "Cuba," in Macmillan Encyclopedia of World Slavery, ed. Paul Finkelman and Joseph Miller (New York: Macmillan, 1997), 231.
} 
precedent for the indentured labor trades that flourished during the 19th and early 20th centuries." Indentured migrant laborers became more important after the 1807 abolition of slave trade in the British Empire, and still more so after 1834, the year of the emancipation of slaves in the empire. Allen points to, for example, "the arrival [in the late 1820s] of approximately 4,600 Chinese and Indian workers in the Mascarene Islands of Mauritius and Réunion," and "the introduction of large numbers of indentured Indians into Mauritius beginning in 1834-1835." Allen also notes, however, that the migration of indentured laborers began earlier than these seeming watershed moments. The British Empire's agents recruited Chinese immigrants to work and live in the British Indian Ocean settlements prior to 1800 . As early as 1806 , British authorities recruited and transported 200 Chinese immigrants to Trinidad. By the early nineteenth century, about 10,000 to 12,000 Chinese were migrating to Southeast Asia every year. According to Allen, the French colonial empire similarly sought indentured labor for its colonies, in this case through contractual agreements called the "engagé system." By the mid- to late 1820s, 3,100 Indian laborers were recruited as engagés for Réunion, and between 1849 and the 1880s, about 79,000 Indian engages were sent to the island. Allen suggests that the drive to increase the use of indentured labor came in part from British abolitionists, who, in their "desire to bring an end to slavery," also pushed for the recruitment of indentured workers in order to "demonstrate[e] the superiority of 'free' over slave labor in the production of tropical commodities." ${ }^{.184}$ But as Dal Lago shows in his review of the

\footnotetext{
${ }^{184}$ Allen, Richard B. "Asian Indentured Labor in the 19th and Early 20th Century Colonial Plantation World." Oxford Research Encyclopedia of Asian History (Cambridge, UK: Cambridge University Press,
} 
Cuban ingenios, the indentured Chinese workers there, treated as harshly as the enslaved, often rebelled against and resisted the plantation management, and probably did not serve to showcase to colonial employers the abolitionists' ideal image of "free" labor.

Notable in this nineteenth-century era of technological innovation and market expansion was the growing need of not just labor, but cheap labor. This was as true for the "Atlantic Plantation System" of the Americas as for the "European Landed Estate System" of eastern and southern Europe, according to Dal Lago. This chapter will skip over Dal Lago's conclusion regarding "second serfdom" in Russia, his representative case for Eastern Europe, as it relies on Blum and Kolchin, and repeats these scholars' view of the equivalence of slavery and serfdom without taking into account the more recent historiography, presented in Chapter II, that challenges this view. In contrast to his dated treatment of serfdom, Dal Lago's survey of the latifundia (large landed estates) of the European South usefully shows how in a setting where labor was "free" and for hire, as opposed to enslaved or enserfed, instituting coercive methods to push down labor cost remained common practice.

If the Americas' "commodity frontiers," as Dal Lago calls the cash crops undergirding the continents' expanding agricultural production, were "cotton, sugar, and coffee," the "commodity frontiers" of Europe were "grain, olive oil, citrus, and wine grapes," a great portion of which was grown in the latifundia of Spain and southern Italy. The "abolition of the feudal system," by which Dal Lago presumably means the abolition

1999): https://oxfordre.com/asianhistory/view/10.1093/acrefore/9780190277727.001.0001/acrefore9780190277727-e-3. Date accessed: December $2^{\text {nd }}, 2019$. 
of hereditary forms of bondage tying peasants to the land and their landlords, occurred in southern Italy in the early nineteenth century, and in Spain in the 1840s. Thus, as Dal Lago points out, the southern Italian and Spanish peasants cultivating the latifundia were "legally free," yet remained heavily exploited by the latifundia owners, as peasants after gaining their "freedom" had little access to land and scant chance of becoming landowners themselves. Called braccianti in Italy and jornaleros or eventuales in Spain, peasants who became landless day laborers filled "a very large reservoir" of the latifundia's casual workers, whose employment was largely seasonal and dependent on the commercial needs of the "orange groves, olive tree fields, and vineyards" that hired them. Less casual, but equally vulnerable was the labor of sharecropping tenants, as the land rental leases they signed "could easily become instruments of exploitation in the hands of ruthless landlords," Dal Lago writes, as the leases allotted land to tenants for ten to fifteen years, after which, "just as the plants began to have fruits," the land would revert to the landowners and deprive the tenants an equitable share of their decades-long labor. $^{185}$

The trend toward using labor that was "free" in legal terms, but in practice maintained through coercion, began before the "emancipation" of unfree labor, exemplified by employment of indentured Asian migrants, and continued after “emancipation" was instituted, as Dal Lago shows for the latifundia of south and southwestern Europe starting in the early nineteenth century. Similarly, after slavery's abolition in the United States, Cuba, and Brazil, between the 1860s and the 1880s, this

185 Dal Lago, "Second Slavery," 392, 404, 408-409. 
trend of employing nominally "free" labor that was maintained through coercion persisted.

On the cotton plantations in the post-emancipation U.S. South, Sven Beckert writes, the abolition of slavery did not end exploitive and brutal labor practices, as "new forms of labor" arose with "new forms of coercion, violence, and expropriation." In 1866, right after emancipation, planters in Georgia and North Carolina, for instance, began hiring on contract the newly freed slaves to cultivate the plantations and paid wages. The pay, in money or in crop shares, was minimal, and the work onerous. Under these terms, the plantations' workforce, now freedpeople, continued to "liv[e] in the hovels they had inhabited before emancipation," cultivating and maintaining the plantations supervised by overseers, according to Beckert. The post-emancipation era's new legal codes worked in conjunction with the terms of the freedpeople's employment contract to discourage mobility and hold them to the plantations. In Mississippi, a few months after slavery's abolition, for example, as Beckert shows, "so-called black codes" were passed that inserted into the contracts freedpeople were to sign terms that "defined mobility as "vagrancy,", which worked to fix the emancipated labor force in place, ${ }^{186}$

With tenuous access to land and subsistence crops, Beckert notes, freedpeople were forced to accept sharecropping agreements that pushed them to grow cotton in exchange for a share of the cash crop. These agreements often deepened their dependency on planters, who charged "exorbitant" rates for necessities and supplies, leading sharecroppers to fall into constant indebtedness. Sharecropping quickly replaced the

${ }^{186}$ Sven Beckert, Empire of Cotton: A Global History (New York: Alfred A. Knopf, 2014), 280, $282,284$. 
"gang labor" common in the pre-emancipation days, according to Beckert. By as early as 1868, sharecropping contracts were "widespread" in the Yazoo-Mississippi Delta, and the turn of the twentieth century, "more than three-quarters of all black farmers in Arkansas, South Carolina, Mississippi, Louisiana, Alabama, and Georgia were sharecroppers," Beckert writes. The economic constraints built into the contracts, buttressed by legal codes, political disenfranchisement, and outright violence, including lynching, Beckert shows, brought on a situation that "all but certain" compelled Black farmers "to grow cotton,[even as] growing cotton would create poverty." By the 1900s, Beckert concludes, the freedpeople forced into growing cotton by a myriad of economic, political, and coercive set-ups "still lived in grinding poverty with few rights and no political voice."187

Examining the "boundaries of freedom" in the post-emancipation sugar industry in the Americas, Rebecca J. Scott finds that in Cuba, Brazil, and Louisiana, compared to the plight of the enslaved in the pre-abolition era, the freedpeople "were differently situated in terms of access to productive and organizational resources," which allowed them to better protest against the inequities imposed by the plantation owners. Nevertheless, every gain was achieved only through prolonged struggle and negotiation. Well into the early twentieth century, as Scott shows, a substantial number of freedpeople remained impoverished due to the terms of the labor contracts and the political interactions that became "imprinted" into the "socio-political environment" of sugar production in these regions. ${ }^{188}$

\footnotetext{
${ }^{187}$ Beckert, Empire of Cotton, 284-288.

${ }^{188}$ Rebecca J. Scott, "Defining Boundaries of Freedom in the World of Cane: Cuba, Brazil and Louisiana after Emancipation," American Historical Review 00, no, 1 (February 1994): 99.
} 
Different from cotton growing, for which tenancy and sharecropping were the most common forms of labor arrangement in Louisiana, as in other parts of the U.S. South, in the sugar industry "wage labor ... was the overwhelming pattern for African Americans in the Sugar Bowl,' Scott writes. This pattern resulted from the planters' preference for "long-term contracts that ensured gang labor," and from efforts to "replicat $[\mathrm{e}]$... the longstanding racial divide" that left what Scott calls "semiindependent cane farming" to white farmers. Thus, within a decade of emancipation, not only were post-emancipation African Americans in sugar cultivation overwhelmingly wage laborers, but wage labor on the plantations consisted in turn predominantly of African Americans. In 1887, between 6,000 and 10,000 cane field workers in the Terrebonne and Lafourche parishes stopped work in protest against planters' intent to reduce wages and pay in scrip. At the Lafourche parish seat of Thibodaux, aided by the state's militia, local whites siding with the planters went after the strikers and executed at least thirty Black men they believed took part in the strike. The killings that came to be known as the Thibodaux massacre broke the strike, chased out labor organizers, and “politically silenced” Louisiana's sugar workers for decades afterward, according to Scott. ${ }^{189}$

In the Spanish colony of Cuba, there were about 173,000 enslaved people as of the 1860s. Between 1880 and 1886, the year of slavery's formal abolition, colonial administrators devised the half-way institution of "apprenticeship" as a transitional measure to prepare for abolition. By these pre-emancipation years, about 100,000 gained

${ }^{189}$ Scott, “Defining Boundaries,” 75, 78, 80. 
freedom by various means, such as "self-purchase, flight, lawsuits, and individual negotiations," with the push to manumission coming from the "determination of slaves, apprentices, and [anticolonial] rebels," Scott writes. After emancipation, the formerly enslaved often became colonos (cane farmers) who signed contracts with sugar plantations' highly mechanized mills to process and transform the cane they harvested "into a saleable commodity." The colonos became by force of these contracts dependent on the ingenios, and Scott describes their type of labor as more "a kind of "contract farming"" than tenancy. The colonos were not a majority among the plantations' postemancipation workforce. In Cuba as a whole, due both to the importation of indentured workers and to the difficult access to land in some regions, "most people of color labored for wages." Where the colonos did flourish, it was often because they managed to obtain some land, grow subsistence crops on their little plots, and in that way "avoid complete proletarianization," Scott observes. However, their life remained precarious, for "the plantation hands," as a 1902 report referred to the colonos, "are not assured permanent employment," which "leads them to depend upon the products of [their] garden patches and other small holdings ... and to limit their needs to what these can supply." Interestingly, the North American author of this report found that this predicament turned the colonos into "a less reliable source of labor." As Scott notes, reflecting on this report, the colonos" "reduced 'needs" and their "unreliability" constituted for them "a longstanding survival strategy."190

190 Scott, “Defining Boundaries”, 81-83, 86-87. 
The sugar-growing region of northeastern Brazil, although "eclipsed" by the coffee-growing regions of the Brazilian south, still had "hundreds of thousands of slaves" as of the 1870s, according to Scott. Since then many of them were sold to coffee plantations, and a number was manumitted as the Brazilian sugar industry declined, beat out by Cuban plantations on the international market. Despite sugar's decline, the majority of the enslaved in the region were not freed until 1888. On the eve of the emancipation in 1888 there remained 77,000 enslaved people in Bahia, and 41,000 in Pernambuco. ${ }^{191}$

In the transition toward the post-emancipation era, the sugar industry devised what Scott identifies as "hybrid work forms" that included the use of cane farmers (lavradores de cana) on contract. These forms of labor, she notes, offered the industry "considerable flexibility," as they required comparatively little cash outlay while keeping on hand "a reserve force of potential laborers." After emancipation, the situation of the lavradores de cana resembled that of the colonos. "Like the colonos in Cuba, their wealth, status, and racial categorization varied, and the term lavradores de cana initially included landowners, renters, and sharecroppers," writes Scott. In Brazil, a greater portion of former slaves became cane farmers than in Cuba, and along with cane furnishers (fornecedores de cana) who purchased cane from the farmers for the large central mills, the lavradores de cana made up "a rural middle group, some in decline and some in ascent," Scott points out. Nevertheless, the general trend for the formerly enslaved was toward wage labor rather than tenancy, and the rural population to which

${ }^{191}$ Scott, “Defining Boundaries," 91-92. 
they belonged became "as a whole ... extraordinarily poor and hungry." According to Scott, few of them were able to "become share-tenants in cane ..., and fewer still made it to the next rung." In 1922, a Brazilian government report showed that day labor was widespread in rural Bahia, with laborers working por empreitada (by the job), receiving at times money, at times only "food and merchandise" as pay. In Pernambuco wages were lower relative to Bahia, another study shows, as migrants from the Brazilian interior competed against Pernambuco's laborers for employment. ${ }^{192}$

Thus, from emancipation's immediate aftermath to decades after, even the least proletarianized of Louisiana, Cuban, and Brazilian sugar plantation laborers remained impoverished, dependent on the plantations, and hardly a model of the ideal of "free" and independent labor that inspired the anti-slavery movement.

\section{"Freedom" and "Unfreedom," or Inequalities?}

Noting the post-emancipation predicament of former slaves and wage laborers in cash-crop production, many scholars characterize this era's wage and indentured labor as resembling slavery, since "free" labor turned out to be in practice merely a "legal fiction," as Alessandro Stanziani puts it when he conveys this view. Stanziani objects to this characterization of the near equivalence of slavery and indentured and wage labor, for it "deprives the abolition of slavery of any historical significance," and overlooks the agency of indentured workers who fought to assert what rights they had. In addition, because this characterization pivots between the poles of "freedom" and "unfreedom" in

${ }^{192}$ Scott, “Defining Boundaries," 94, 97-98. 
its depiction of labor types, Stanziani suggests, it fails to capture the spectrum of varying coercive relationships that developed between planters and laborers, both in the time of slavery and afterwards. He argues instead for an interpretive approach questioning the notion of a clear distinction between free and unfree labor, a notion that permeated historical debates and current scholarship alike, ${ }^{193}$

In place of presuming a dichotomous division between free and unfree labor, Stanziani turns to examine the legal inequalities that shaped labor relationships, expressed in different types of labor contracts. Stanziani argues against taking for granted, as do many scholars of labor and capital in the West, the vision of an "abstract wage earner" as the representative figure of "free labor," a figure that arose from an idealized conception of the "free labor market," where "legally equal actors" signed contracts that all parties could invoke the law to enforce. Stanziani asserts that such a figure did not exist in historical reality, as the legal codes of Europe in the pre- and early industrial eras were replete with built-in inequalities between workers and masters, and as demonstrated by the experience of historical actors. He proposes, rather, that it was the figure of the "the servant" that exerted a real historical impact in shaping labor relations. In the legal codes and contracts of France and Britain, which Stanziani investigates, those who sold their work or labor were treated as "servants," a status group that had very restricted legal rights and little say over labor contracts. But these contracts were not entirely a "fiction," since over time, through legal and extralegal struggles, laborers were

\footnotetext{
193 Alessandro Stanziani, "Local Bondage in Global Economies: Servants, Wage Earners, and Indentured Migrants in Nineteenth-Century France, Great Britain, and the Mascarene Islands," Modern Asian Studies 47, no. 4 (2013): 1219-1220.
} 
able to modify the contract terms and the extent of their rights, in part by making claims based on the rights already defined in the contracts. ${ }^{194}$

In the case of France, the revolution eliminated the old regime and removed criminal sanctions against workers built into their contracts, but left in place "significant contractual inequalities" favoring employers that endured into the third quarter of the nineteenth century, according to Stanziani. Among the different types of laborers entering into contractual agreements with employers, aside from day laborers, who were often seasonal workers, were "servants in husbandry," who tended to be more closely tied to their masters, sometimes living with them and performing domestic services. These “servants" earned wages (gages), and were repeatedly considered by French law, in 1848, 1849 , and 1850 , to have the legal standing of a worker who "voluntarily subordinates himself to the master," in the words of the judicial documents Stanziani quotes; this means that the master had, therefore, by law the right to make many decisions that affected the condition of the servant. Stanziani suggests that the wage-earning servant was the model for indentured workers in the French colonies. The indentured laborers sent to these colonies in the seventeenth century signed contracts of engagement that were based on "already existing contracts" written for agricultural laborers and sailors, and that specified, since they were old regime contracts, that the engagés were "subject to criminal penalties" for breach of contract, and to "be[ing] transferred along with their contracts to other masters."195

\footnotetext{
194 Stanziani, "Local Bondage," 1221, 1236, 1248..

195 Stanziani, "Local Bondage," 1221-1222, 1226-1227.
} 
Regarding Britain, the author points to labor codes assembled in the sixteenth century that lasted into most of the nineteenth. These codes governed the relationship between masters and the workers who provided services to them, variously designated as servants, artificers, and apprentices. Collectively referred to as the Masters and Servants acts, these rules were supplemented by the Statute of Artificers and Apprentices of 1562 . Defining in effect some of the key terms that indentured contracts would be modeled on, as Stanziani notes, the Masters and Servants acts and the Artificers and Apprentices statute gave "apprentices, servants, and any other type of wage earners" fewer rights than their masters and employers, and therefore also "an inferior legal status." These legal measures, in Stanziani's words, identified as "fugitives" those "who left their employment without giving notice," and granted masters the right to recover “"fugitives." These measures further conferred on the master a broad range of other rights, including that of imposing corporal punishment, of "sell[ing] the indentured servant along with any debts he owed to someone else," and of "authoriz[ing] the marriage of indentured servants." 196

Contrary to what many scholars who encounter them believe, the harsh penalties targeting "servants" in these codes were not anomalies, Stanziani insists. The author finds that between 1750 and 1875, in Britain itself, not to speak of the British colonies, the codes were actively and increasingly enforced, for they served "as a powerful tool in the hands of master/employers to cope with increasing demand for labour" in an era when global trades were accelerating and rapidly growing in volume. In this period, there were

196 Stanziani, "Local Bondage," 1222, 1237, 1239, 1242-1243. 
about 10,000 cases of prosecution against laborers who violated the Masters and Servants acts, with many more settled out of court. The sentences meted out included fines, docked wages, detention in a house of correction, and, on rare occasions, whipping. The codes were also unequally enforced, as few masters were prosecuted for violation. Nevertheless, Stanziani states, though unusual, workers did attempt to sue their masters, mainly for unpaid wages or unjustified dismissal. These worker-initiated cases pointed toward new trends that "ultimately changed the balance of power in the labour market," Stanziani writes, noting that such a change was first signaled by the decriminalization of "employment offences" in the Employers and Workmen Act of 1875, fourteen years after the abolition of serfdom in the Russian Empire. ${ }^{197}$ Taken together, these French and British labor codes were not very different from the restrictions of bondage imposed on the peasants and the enserfed in Russia during the same period of the seventeenth to the latter part of the nineteenth century, when these codes were active.

Turning to look at the French and British colonies in the Indian Ocean, Reunion Island and Mauritius, rather than separating this European "periphery" from Europe's "core," Stanziani argues that the labor contracts of both the empires' metropolis and the colonies all involve "actors (masters, servants, day labourers, indentured immigrants) [who] belonged to one and the same world comprising legal inequalities between employers ... and workers." There are notable differences, however, as Stanziani recognizes, since, great as the inequalities were in metropolitan France and Britain, they

197 Stanziani, "Local Bondage," 1240-1242. 
were "far greater in the colonies," and continued to be so well after the official abolition of slavery in 1834 for the British Empire, and in 1848 for the French. ${ }^{198}$

Between 1830 and 1920, in all about a quarter of the two million indentured servants who were sent to work on tropical plantations, or half a million laborers, arrived on the islands. They included emigrants from India, and Madagascar, Mozambique, and China. On Reunion, laborers recruited based on the contracts of engagement began to work on the island since the 1810s, many of them from India. By 1830, the number of Reunion's Indian engagés reached 3,000. In 1847, there were 6.508 engagés on the island, made up of "Indians, Chinese, Africans, and Creoles." Between 1849 and 1859, reflecting the effect of slavery's abolition in the French colonial empire, the number Reunion's engagés shot up to 44,000. In Mauritius, the first engagés arrived in the 1720s, when the island was a French possession known as Ile de France, and they were brought from India and other French colonies. After the British takeover of the island in 1810, indentured servants continued to be transported there, with many of them now coming from, besides India, Madagascar and East Africa. Between 1834 and 1910, showing the impact of the British abolition of slavery, Mauritius's population of indentured servants grew to $450,000 .^{199}$

The colonial contracts of engagement and indenture contained similar terms as the contracts in metropolitan France and Britain, Stanziani shows. Like the metropolitan labor contracts for agricultural work, those drawn up for the colonies granted workers

\footnotetext{
198 Stanziani, "Local Bondage," 1220

199 Stanziani, "Local Bondage," 1221, 1228-1230, 1243,1244.
} 
some legal rights, such as the right to challenge employers in court for labor abuses. But, as Stanziani observes, in practice these rights were "largely ignored." At the same time, unlike labor relations in the metropole, the abuses in the colonies were more extreme. To begin with, the recruitment of laborers was often conducted by force or fraud, and frequently with the assistance of a wide range of intermediaries who perhaps did not have in mind the best interest of the recruits. They included "Indian, Arab, and Portuguese middlemen," along with "local sultans and village chiefs."200

Colonial indenture and engagement contracts provided for repatriation. But, Stanziani observes, "in practice ... repatriation was difficult," particularly since many workers were compelled to renew their contracts. Between 1850 and 1860 s, only one third of the indentured immigrants sent to Reunion and Mauritius returned home, compared to the 70 percent repatriation rate for the worker-immigrants to Thailand, Malaya, and Melanesia. Indentured workers on the islands faced brutal treatment, which at times led to death. In addition, they were often subjected to withheld wages and inadequate food provision. The contracts, to discourage robbery and theft, allowed even minor infractions to be punished severely. Thus, according to Stanziani, as late as the 1860s and 1870s, well after slavery's abolition in the French and British empires, for a stolen chicken, some indentured immigrants were sentenced to five years of forced labor, and, for refusing to turn over their savings to their employers, a number of "Chinese "coolies" were punished by seven years of forced labor. The indenture contracts also aimed to discourage "the mobility of workers and peasants in the rest of the British

200 Stanziani, "Local Bondage," 1228,1230-1234, 1244. 
empire," notes Stanziani. The French engagé contracts shared this aim. In the case of Mauritius, as Stanziani states, this intent to limit mobility was strengthened by laws that were drawn up, as late as the 1870s, against "vagrancy."201

\section{Conclusion}

Regarding serfdom in the Russian Empire, the work of Revisionist Historians such as Alessandro Stanziani and David Moon, and that of the historians of global labor history reviewed in this chapter, show the extent to which the interpretation of serfdom offered by Consensus Historians such as Jerome Blum and comparative labor historians such as Peter Kolchin may have been flawed. Blum, Kolchin, and other historians who assert the equivalence of serfdom and slavery, and a vision of serfdom as the diametrical opposite of "free" labor, may have been misled by the type of documents they used (often the works of previous historians, rather than archival documents relating to estates activities and court cases, to which they did not have access because of the Cold War). More importantly perhaps, they were also shaped by preconceptions about the necessary link between "unfree" labor and backward societies. Relying on the studies of earlier scholars, who may themselves have been influenced by a belief in a clear-cut divide between free and unfree labor, historians like Blum and Kolchin were unable to perceive the myriad of ways serfdom in Russia, while imposing numerous restrictions on the enserfed, also allowed room for negotiation and modification over time. In this way Russian serfdom came close to, and at times, as suggested by the serf memoirs in Chapter

${ }^{201}$ Stanziani, "Local Bondage," 1232-1234, 1247. 
III, permitted more leeway than the forms of labor encouraged and proliferated in the "free" and "advanced" societies of the West. These forms of labor include that of the indentured servants, represented for instance by tenant farmers, Chinese and Indian "coolies," and that of the wage (gage) earner, a figure often taken as the emblem of "free" labor that was in fact also the model for the French, Indian, Chinese, Malagasy, and Mozambique engagés. 


\section{Bibliography}

Allen, Jerome. The End of the Old Order in Rural Europe, Princeton, NJ: Princeton University Press, (1978):

Allen, Richard B. "Asian Indentured Labor in the 19th and Early 20th Century Colonial Plantation World." Oxford Research Encyclopedia of Asian History, (2017): 1-19.

Anisimov, Evgenii V. The Reforms of Peter the Great: Progress through Coercion in Russia, trans. John T. Alexander, Armonk, NY: M.E. Sharpe, 1993.

Bartlett, Roger. "Serfdom and State Power in Imperial Russia," European History Quarterly 33. no. 1 (2003): 29-64.

Bayly, C.A., The Birth of the Modern World, 1780-1914 Oxford, and Malden, MA: Blackwell, 2004.

Beckert, Sven. Empire of Cotton: A Global History New York: Alfred A. Knopf, 2014.

Blum, Jerome. Lord and Peasant in Russia: From the Ninth to the Nineteenth Century. Princeton: Princeton University Press, 1972.

The End of the Old Order in Rural Europe Princeton, NJ: Princeton University Press, 1978.

. "The Rise of Serfdom in Eastern Europe," The American Historical Review 62. no. 4 (1957): 807-836. 
Brower, Daniel R. and Layton, Susan. "Liberation through Captivity: Nikolai Shipov's Adventures in the Imperial Borderlands," Kritika: Explorations in Russian and Eurasian History 6, no. 2 (Spring 2005): 259-278.

Confino, Michael. “Servage russe, esclavage américain,” Annales ESC 45, no. 5 (September-October 1990): 1119-1141.

Crisp, Olga, "The State Peasants under Nicholas I," in Studies in the Russian Economy before 1914, ed. Olga Crisp (London: Palgrave Macmillan, 1976), 88-89.

Crisp, Olga. Studies in the Russian Economy before 1914. London: Macmillan [for] the School of Slavonic and East European Studies, University of London, 1976.

Dal Lago, Enrique. "Second Slavery, Second Serfdom, and Beyond: The Atlantic Plantation System and the Eastern and Southern European Landed Estate System in Comparative Perspective, 1800-60," Review (Fernand Braudel Center) 32, no. 4 (2009): 391-420.

de Soto, H. The Mystery of Capital: Why Capitalism Triumphs in the West and Fails Everywhere Else. New York: Basic Books, 2007.

Dennison, T.K. “Did Serfdom Matter? Russian Rural Society, 1750-1860,” Historical Research 79, no. 203 (2006): 74-89.

Domar, Evsey D. Capitalism, Socialism, and Serfdom: Essays. Cambridge, UK: Cambridge University Press, 1989. 
Domar, Evsey D. and Machina, Mark J. "On the profitability of Russian Serfdom," Journal of Economic History, no. 4 (December 1984): 929.

Esper, Thomas. "The Condition of the Serf Workers in Russia's Metallurgical Industry, 18001861," The Journal of Modern History 50, no. 4 (Dec., 1978): 660-679.

Evtukov, Catherine, "Portrait of a Russian Province: Economy, Society, and Civilization in Nineteenth-Century Nizhnii Novgorod," (Pittsburg, PA: University of Pittsburg Press, 2011), 73.

Field, Daniel. The End of Serfdom: Nobility and Bureaucracy in Russia, 1855-1861. Cambridge, MA: Harvard University Press, 1976.

Fitzpatrick, Anne Lincoln “The Great Fair: Nizhnii Novgorod, 1840-1890.” (New York: St. Martin's Press, 1990).

Freeze, Gregory. "The Soslovie (Estate) Paradigm and Russian Social History," American Historical Review, 91, no.1 (February) 1986): 11-36.

Gammer, Moshe, “'The Conqueror of Napoleon' in the Caucasus," Central Asian Survey 12, no. 3 (1993): 253.

Gerschenkron, Alexander. Economic Backwardness in Historical Perspective: A Book of Essays. Cambridge, MA: Belknap Press of Harvard University Press, 1962.

Glen, Robert. Urban Workers in the Early Industrial Revolution. London: New York: Croom Helm; St. Martin's Press, 1984. 
Haperin, Charles J. “Contemporary Russian Perceptions of Ivan IV's Oprichnina," Kritika: Explorations in Russian and Eurasin History 18, no. 1 (Winter 2017): 99102.

Hellie, Richard. Enserfment and Military Change in Muscovy. Chicago: University of Chicago Press, 1971.

Hoch, Steven L. Serfdom and Social Control in Russia: Petrovskoe, a Village in Tambov. University of Chicago Press, 1989.

Kolchin, Peter. Unfree Labor: American Slavery and Russian Serfdom. Cambridge, MA.: Belknap Press of Harvard University Press, 1987.

Kotsonis, Yanni. States of Obligation: Taxes and Citizenship in the Russian Empire and Early Soviet Republic Toronto: University of Toronto Press, 2014.

Lincoln, W.B. In the Vanguard of Reform: Russia's Enlightened Bureaucrat, 1825-1861. DeKalb, IL: Northern Illinois University Press, 1982.

MacKay, John Kenneth. Four Russian Serf Narratives. Madison, WI: University of Wisconsin Press, 2009.

Marquese, Rafael de Bivar, "African Diaspora, Slavery, and the Paraiba Valley Coffee Plantation Landscape: Nineteenth-Century Brazil," Review (Ferdinand Braudel Center) 31, no. 2 (2008): 202. 
Melton, Edgar, "Enlightened Seigniorialism and Its Dilemmas in Serf Russia, 17501830.” The Journal of Modern History 62, no. 4 (1990): 676-708.

Moon, David. "Reassessing Russian Serfdom," European History Quarterly 26, no. 4 (1996): 483-526.

Nicholas V. Riasanovsky and Mark D. Steinberg, A History of Russia, $8^{\text {th }}$ Edition New York: Oxford University Press, 2011.

Nikitenko, Aleksandr. Up from Serfdom: My Childhood and Youth in Russia 1804-1824. Trans. Helen Saltz Jacobson. New Haven, CT: Yale University Press, 2001.

Paquette, Robert L. "Cuba," in Macmillan Encyclopedia of World Slavery, ed. Paul Finkelman and Joseph Miller New York: Macmillan, 1997, 231.

Pieterse, Jan Nederveen, "The Long Nineteenth Century Is Too Short," Victorian Studies 48, no. 1 (Autumn 2005): 113-123.

Pipes, Richard. "Private Property Comes to Russia: The Reign of Catherine II," Harvard Ukrainian Studies, 22 (1998): 435-437.

Pollard, Sidney. "Factory Discipline in the Industrial Revolution," Economic History Review 16, no. 2 (1963): 254-71.

Purlevskii, Savva Dmitrievich. A life under Russian serfdom: the memoirs of Savva Dmitrievich Purlevskii, 1800-1868. Budapest, Hungary: Central European University Press, 2005. 
Radischchev, Aleksandr Nikolaevich. A Journey from St. Petersburg to Moscow. trans. Leo Wiener. Cambridge, MA: Harvard University Press, 1958

Randolph, John. "Communication and Obligation: The Postal System of the Russian Empire, 1700-1850," in Information and Empire: Mechanisms of Communication in Russia, 1600-1850, ed. Simon Franklin and Katherine Bowers (Cambridge, UK: Open Book Publishers, 2017), 155-184.

Scott, Rebecca J. "Defining Boundaries of Freedom in the World of Cane: Cuba, Brazil and Louisiana after Emancipation,” American Historical Review, no, 1 (February 1994): 99.

Stanziani, Alessandro. "Beyond Colonialism: Servants, Wage Earners and Indentured Migrants in Rural France and on Reunion Island (C. 1750-1900),” Labor History, 54, no. 1 (2013): 64-87.

. Bondage: Labor and Rights in Eurasia from the Sixteenth to the Early Twentieth Centuries New York: Oxford; Berghahn Books, 2014.

—. "Free Labor_-Forced Labor: An Uncertain Boundary? The Circulation of Economic Ideas between Russia and Europe from the 18th to the Mid-19th Century," Kritika: Explorations in Russian and Eurasian History 9, no. 1 (2008): 27-52.

_ . "Revisiting Russian Serfdom: Bonded Peasants and Market Dynamics, 1600s1800s," International Labor and Working-Class History 78, no. 1 (2010): 12-27. 
—_. "Russian Serfdom: A Reappraisal," Ab Imperio 2014, no. 2: (2013): 71-

99.

-."Introduction: Labour Institutions in a Global Perspective, from the Seventeenth to the Twentieth Century," International Review of Social History 54, no. 3 (2009): 351-358.

."Local Bondage in Global Economies: Servants, Wage Earners, and Indentured Migrants in Nineteenth-Century France, Great Britain, and the Mascarene Islands," Modern Asian Studies 47, no. 4 (2013): 1218-1251.

-."Serfs, Slaves, or Wage Earners? The Legal Status of Labour in Russia from a Comparative Perspective, from the Sixteenth to the Nineteenth Century," Journal of Global History 3, no. 2 (2008): 1044-1068.

-"The Traveling Panopticon: Labor Institutions and Labor Practices in Russia and Britain in the Eighteenth and Nineteenth Centuries," Comparative Studies in Society and History 51, no. 4 (2009): 715-741.

Thompson, E.P. "The Moral Economy of the English Crowd in the Eighteenth Century," Past and Present, 50 (1971): 76-136.

Tomich, Dale. "The 'Second Slavery': Bonded Labor and the Transformation of the Nineteenth-Century World Economy," Critical Readings on Global Slavery (4 vols.) (n.d.), 1326-1349. 
Tomich, Dale., Zeuske, Michael. "Introduction, The Second Slavery: Mass Slavery, World Economy, and Comparative Microhistories," Review (Fernand Braudel Center) 31, no. 2 (2008): 91.

Wallerstein, Immanuel. The Modern World System, Capitalist Agriculture and the Origins of European World Economy in the Sixteenth Century New York, Academic Press, 1974.

Wirtschafter, Elise Kimerling. "Legal Identity and the Possession of Serfs in Imperial Russia," Journal of Modern History 70 (September 1998): 569.

Yun, Lisa. and Laremont, Ricardo Rene. "Chinese Coolies and African Slaves in Cuba, 1847-74," Journal Asian American Studies 4, no. 2. (June 2002): 99-122. 